NBER WORKING PAPER SERIES

\title{
THE MEDIUM-TERM IMPACTS OF GIRL-FRIENDLY SCHOOLS: SEVEN-YEAR EVIDENCE FROM SCHOOL CONSTRUCTION IN BURKINA FASO
}

\author{
Harounan Kazianga \\ Leigh L. Linden \\ Ali Protik \\ Matthew Sloan \\ Working Paper 26006 \\ http://www.nber.org/papers/w26006 \\ NATIONAL BUREAU OF ECONOMIC RESEARCH \\ 1050 Massachusetts Avenue \\ Cambridge, MA 02138 \\ June 2019
}

This paper is based on an evaluation of the second phase of the Burkina Faso's BRIGHT program funded by the Millennium Challenge Corporation (MCC), a U.S. government agency. We are grateful to several officials at MCC, for their help throughout the project. We are also grateful to the staff of MCA-Burkina Faso in Ouagadougou and to the officials from the Ministry of Education. We would like to thank Mikal Davis, Caroline Lauver, Isabel Krakoff and Cara Orfield for excellent research assistance. Finally, we would also like to thank seminar participants at APPAM, at MCA-Burkina, at MCC, at IFPRI and at the World Bank. Harounan Kazianga acknowledges the support of the Carson Priority Professorship. This research was also supported by grant P2CHD042849 Population Research Center, awarded to the Population Research Center at The University of Texas at Austin by the Eunice Kennedy Shriver National Institute of Child Health and Human Development. The content is solely the responsibility of the authors and does not necessarily represent the official views of the National Institutes of Health. The views expressed herein are those of the authors and do not necessarily reflect the views of the National Bureau of Economic Research.

NBER working papers are circulated for discussion and comment purposes. They have not been peer-reviewed or been subject to the review by the NBER Board of Directors that accompanies official NBER publications.

(C) 2019 by Harounan Kazianga, Leigh L. Linden, Ali Protik, and Matthew Sloan. All rights reserved. Short sections of text, not to exceed two paragraphs, may be quoted without explicit permission provided that full credit, including $\odot$ notice, is given to the source. 
The Medium-Term Impacts of Girl-Friendly Schools: Seven-Year Evidence from School Construction in Burkina Faso

Harounan Kazianga, Leigh L. Linden, Ali Protik, and Matthew Sloan

NBER Working Paper No. 26006

June 2019

JEL No. I24,I25,I28,O15

\section{ABSTRACT}

We evaluate the long-term effect of a "girl-friendly" primary school program in Burkina Faso, using a regression discontinuity design. The intervention consisted of upgrading existing threeclassroom schools to six-classroom schools to accommodate more grades. After seven years, the program increased enrollment by 15.5 percentage points and increased test scores by 0.29 standard deviations. Students in treatment schools progress further through the grades, compared to students in non-selected schools. These upgraded schools are effective at getting children into school, getting children to start school on time, and keeping children in school longer. Overall, we find that the schools sustain the large impacts observed about three years earlier, with enrollment declining slightly from 18.5 to 14.9 for the cohorts of children who were exposed to both the first and second phases of the intervention.

Harounan Kazianga

Oklahoma State University

Department of Economics

324 Business Building

Stillwater, OK 74078

harounan.kazianga@okstate.edu

Leigh L. Linden

Department of Economics

The University of Texas at Austin

2225 Speedway

BRB 1.116, C3100

Austin, Texas 78712

and NBER

leigh.linden@austin.utexas.edu
Ali Protik

NORC at The University of Chicago

4350 East-West Highway, 8th Floor

Bethesda, MD 20814

protik-ali@norc.org

Matthew Sloan

Mathematica Policy Research 1100

1st Street, NE, 12th Floor

Washington, DC 20002-4221

MSloan@Mathematica-Mpr.com 


\section{Introduction}

The growth in primary school enrollment rates worldwide is one of the major recent success stories of development policy. Unfortunately, not all countries have shared in this achievement. Most notably, children in parts of sub-Saharan and South Western Asia attend primary school at much lower rates than children in the rest of the developing world (Glewwe et al. 2011). In 2011, for example, the developing world had achieved gross enrollment rates of 109 percent $^{2}$, but Mali, Burkina Faso, and Niger, the three worst performing countries in West Africa, averaged a dismal 84, 81, and 67 percent, respectively. Students from these countries are also less likely to complete elementary school, let alone transition to secondary school (Glewwe et al. 2011). Although the rest of the world shifts focus to improving secondary school enrollment rates and improving employment outcomes for older teens and young adults, these countries risk falling further behind.

Quasi universal elementary school participation implies that the gender gap in enrollment has virtually disappeared. In countries where enrollment rates are still low, girls are less likely to be enrolled than boys. In 2011, gross enrollments of boys and girls in the developing world were 111 percent and 107 percent, respectively. In Sub-Saharan Africa, gross enrollments were 105 percent for boys and 97 percent for girls. The gender gap was even wider when considering the countries with the lowest enrollment rates. In the same year, enrollment rates for boys and girls were 85 percent and 79 percent in Burkina Faso; 97 percent and 86 percent in Mali; and 75 percent and 62 percent in Niger. Hence, even by African standards, the gender gap in primary school participation persists in these three countries.

A number of factors influence parents' decisions to enroll children in schools. Economically, the decision reflects a trade-off between the returns to education and the costs of schooling, particularly the opportunity cost of children's time. Within this framework, however, infrastructure seems to play an important role (Alderman, Kim, and Orazem 2003; Breierova and Duflo 2004; Duflo 2001; Handa 2002; Paxson and Schady 2002) ${ }^{3}$. Reducing the costs of schooling by building

\footnotetext{
${ }^{2}$ Figures on country level gross enrollment rates are from the UNESCO Institute for Statistics (http://www.uis.unesco.org/Pages/default.aspx).

${ }^{3}$ Duflo (2001) shows a substantial increase in the number of schools in Indonesia led to an increase in educational attainment of an average of 0.12 to 0.19 years of schooling for men, with sizable increases in their economic returns from schooling. Breierova and Duflo (2004) focus on maternal outcomes of the school expansion program in Indonesia and find a strong significant effect on women's educational outcomes. Paxson and Schady (2002) assess the educational impact of Peru's Social Investment Fund during the 1990s. During a six-year period starting in 1992, the
} 
more schools and making them more accessible significantly increases the probability that families choose to enroll children (Kondylis and Manacorda 2012), particularly girls. This is true in developing countries in general, as well as areas with stubbornly low enrollment rates (Burde and Linden 2013; Kazianga et al. 2013; Shaffner 2003; Theunynck 2009). There is also evidence that the quality of the infrastructure matters and that providing amenities targeted at facilitating the enrollment of girls can significantly improve their enrollment (Glewwe and Jacoby 1996; Mason and Rozelle 1994). In addition to attracting and maintaining more students in school, overall school quality has also been shown to improve teachers’ effectiveness (Chaudhuri et al. 2006).

Unfortunately, this literature provides little detail on the process through which infrastructure improves primary school enrollment (Filmer 2007). ${ }^{4}$ Moreover, although there is ample evidence indicating that enrollment increases when the distance to the nearest school decreases, only few studies investigate the effects of improved school facilities on learning outcomes (Burde and Linden 2013; Kazianga et al. 2013). We build on Kazianga et al. (2013) by analyzing a second longer-term, follow-up survey of the unique Burkinabe Response to Improve Girls' Chances to Succeed (BRIGHT) school construction program. The program, which started in 2005, constructed high quality schools with "girl-friendly" characteristics in the parts of the country with the lowest enrollment rates. The Burkinabe Ministry of Education selected villages for the program based on a needs assessment that provides for the use of a regression discontinuity design. The repeated cross-sectional design allows us to use the existing RD design to assess the continued viability of providing high-quality schools seven years after the start of the program during a period in which the schools expand beyond their initial three grades into later primary school grades.

Overall, we find that villages selected for the BRIGHT program continue to have better and higher quality infrastructure and resources with significantly more amenities targeted at improving the enrollment of girls. With only one exception (gender sensitivity training), we find a greater prevalence in these gender-focused characteristics seven years after the start of the program than

\footnotetext{
program engaged in building and upgrading school infrastructure (mainly classrooms). As in the case of Indonesia, Paxson and Schady find that investment in school infrastructures increased enrollment rates, especially for the rural poor, and that school attendance increased, especially for young children.

${ }^{4}$ Notice that expanding schooling options might not consistently improve educational outcomes (Ganimian and Murnane 2014). For instance, Newman et al. (2002) argue that education projects in Bolivia may have improved school infrastructure, but had little impact on education outcomes. On the other hand, Pradhan and Rawlings (2002) find that education investments have a positive impact on schooling outcomes.
} 
at 2.5 years. Additionally, although schools in selected villages remain older than other schools, almost all villages in the sample have access to a school within their village. The difference in the probability that an unselected village has a school is only 9.9 percentage points, and 95.7 percent of selected villages have schools. ${ }^{5}$ These differences imply that the effects observed in the current survey are much more likely due to differences in the quality of the schools rather than just the presence of a school.

The BRIGHT program continues to improve students' enrollment rates significantly. We find that children between the ages of six and seventeen in villages selected for the program are 15.5 percentage points more likely to be enrolled in school and score 0.29 standard deviations more on a standardized achievement test. We find evidence of modest reductions in child labor across a range of household chores, but we find no effects on children's growth for the associated feeding programs. The relative lack of effect of the feeding program is likely due to low school participation rates. Despite the large treatment effects on school participation, primary school enrollment rates in selected villages are only 47.6 percent. Unlike the 2.5 year effects, we now find that the program has significantly larger effects for girls than boys across a range of outcomes, including enrollment, test scores, grade progression, and household work supporting earlier evidence of the importance of the girl-friendly characteristics. Noticeably, the gender gap closes in educational outcomes (enrollment, test scores, grade progression) in selected villages.

The data also provide evidence about how these schools improve children's outcomes. Although we find that the enrollment effects are consistent across children of all ages, the test score effects accrue disproportionately to older children. At the same time, we find that the children in selected villages are much more likely to stay in school longer, matriculating to higher grade levels. This seems to be due largely to the BRIGHT schools' ability to encourage children to start school earlier. In fact, the entire difference in test scores between selected and unselected villages can be explained by the fact that children in selected villages are more likely to have progressed to higher grade levels. We find no evidence that the fact that BRIGHT schools are older or offer more grade levels plays a role.

${ }^{5}$ About 85.8 percent of nonselected villages report having a school. 
The rest of the paper is structured as follows. We present the BRIGHT program in Section II. In Section III, we describe our methodology. We establish the internal validity of our approach in Section IV. We discuss our results in Section V for academic outcomes and in Section VI for secondary outcomes. We investigate heterogeneity in Section VII, and conclude in Section VIII.

\section{Description of the BRIGHT Program}

The BRIGHT program was designed and implemented to improve the educational outcomes of children in Burkina Faso and girls' education in particular in a context where the government was embarked on a 10-year education investment program (Levy et al. 2009 and Kazianga et al. 2013). The first phase of BRIGHT consisted of constructing primary schools with three classrooms from grades one to three and implementing a set of complementary interventions, including separate latrines for boys and girls, canteens, take-home rations and textbooks, and community engagement activities. An independent impact short-term evaluation of the BRIGHT program was carried out in 2009 (Levy et al. 2009, Kazianga et al. 2013) examining the impacts of the program for children between the ages of 5 and 12 .

In the first three years of operation, the BRIGHT program increased enrollment by 20 percentage points, based on the household survey data collected in 2008 (Ley et al. 2009; Kazianga et al. 2013). The impact on whether a child was present on the day we visited the school, however, was 16 percentage points. These effects are in line with other educational interventions that investigate the effects of school construction in developing countries (Duflo 2001, Andrabi Das, and Khwaja 2013). The effects imply that BRIGHT I was responsible for increasing enrollment rates from about 35 percent to 55 percent (household-reported outcome) or from about 31 percent to 47 percent (school-based outcome).

In the first phase of the program, the impact in enrollment was also accompanied by large positive impacts on student test scores, which covered math and French. The impacts on both math and French test scores were approximately 0.4 standard deviations. In this context, an impact of this

size implied that for a student who started at the $50^{\text {th }}$ percentile of our sample, attending a BRIGHT school is predicted to increase his or her test score to approximately the $80^{\text {th }}$ percentile. 
To ensure sustained success of the BRIGHT program, the government of Burkina Faso extended the program using \$28.8 million in compact funding. This second phase of the BRIGHT program was implemented from 2009 to September 2012 and consisted of constructing three additional classrooms from grades four through six in the original 132 villages with the continuation of the complementary interventions provided during the first three years of the program. The complementary interventions included:

- School canteens (daily meals for all): Daily meals were offered to all boys and girls who were enrolled in school.

- Take-home rations: Girls who had a 90 percent attendance rate received 8 kilograms of dry cereal each month to take home.

- School kits and textbooks: Textbooks and school supplies were to be provided to all students.

- Mobilization campaign: The purpose of the mobilization campaign was to bring together communities and those with a stake in the education system to discuss the issues involved in, and barriers to, girls' education. The campaign included informational meetings; door-todoor canvassing; providing gender-sensitivity training to ministry officials, pedagogical inspectors, teachers, and community members; sponsoring a girls' education day; radio broadcasts; posters; and providing awards for female teachers.

- Literacy: The literacy program had two components_-adult literacy training and mentoring for girls. For each of the two project years, Tin Tua organized adult literacy training and training for student mothers/female role models.

- Local partner capacity building: Training included local officials in the Ministry of Education, Bisongo monitors, and teachers. Specific training included completing school registers.

The overarching goal of the BRIGHT program was to increase primary school completion rates for girls, as the government of Burkina Faso identified girls' education as one of the key avenues through which poverty could be reduced while stimulating economic growth. The combination of classroom construction and complementary interventions were meant to yield short-, medium-, and long-term outcomes for girls, parents-mothers, in particular-community members, and teachers. The primary intervention is the construction of girl-friendly schools. These schools can directly affect enrollment and attendance of girls, which in turn could improve their academic 
skills and, in the long-term, their employment prospects and incomes. The additional amenities are likely to contribute to improving girls' enrollment and academic skills, but may also improve other outcomes.

\section{Methodology}

\section{A. Research Design}

The Ministry of Education (MoE) determined the allocation of schools within the BRIGHT program in coordination with MCC. The strategy sought to target villages able to serve the largest number of children via objective, transparent criteria. They proceeded as follows:

1. From the country's 301 departments, 293 villages were nominated from 49 departments due to their low levels of primary school enrollment.

2. A staff member from the MoE administered a survey to each village.

3. The results of the survey then determined each village's score using a set formula that heavily weighted the number of children likely to be served from the proposed and neighboring villages. Girls were given additional weight. ${ }^{6,7}$

4. The MoE then ranked each village within the 49 departments, selecting the top half of villages within each department to receive a BRIGHT school. In the event of an odd number of villages, the median village was not treated, and the two departments that had only a single nominated village had their villages selected.

Ultimately, 127 villages received the BRIGHT program. The selection algorithm identified 138 villages for inclusion in the BRIGHT program, but 11 of these villages did not participate. This seemed to be mainly due to problems with the location. For example, the BRIGHT design called for the creation of a well, but suitable wells could not be dug in some of the proposed villages. Five villages that were not initially selected via the algorithm were selected as replacement villages. It seemed that these were the next highest ranked villages. However, we could not confirm that this was the formal rule nor could we determine why only 5 of the 11 villages were replaced.

\footnotetext{
${ }^{6}$ As noted in Kazianga et al. (2013), the information on which the score is based seems very noisy, probably because the survey was based largely on information provided by the leader of each village. For example, the score is at best weakly correlated with most outcomes both in the prior and current study.

${ }^{7}$ The details of the scoring formula are available in Kazianga et al. (2013).
} 
Because the vast majority of villages received a school in compliance with the selection algorithm, we treat the 16 villages as noncompliers and estimate intent-to-treat effects.

\section{B. Empirical Specifications}

The selection algorithm creates a series of $\mathrm{RD}$ designs within each department. Although the within-department assignment rule is not statistically ideal, we include department level fixed effects in all estimations to ensure that villages are only compared to other villages within the same department. Finally, to transform the score variable used to assign schools such that all villages received the BRIGHT program if their score was larger than the same value, we calculate for each department the midpoint between the scores of the highest scoring village not assigned to receive the program via the algorithm and the lowest scoring village assigned to it. The variable Rel_Score $_{\mathrm{j}}$ is then defined to be the village score relative to this midpoint. It is the value of the midpoint subtracted from each village's score. We then estimate treatment effects via the following model using ordinary least squares:

$$
y_{\text {ihjk }}=\beta_{0}+\beta_{1} T_{j}+f\left(\text { Rel_Score }_{j}\right)+\delta X_{\text {ihjk }}+\gamma Z_{k}+\varepsilon_{\text {ihjk }}
$$

The estimates are performed at the child-level with each child designated as child $i$ in household $h$ in village $j$ in department $k$. We designate the outcome of interest with the variable $y_{i h j k}$. The matrix $Z_{k}$ is a vector of department fixed effects, and $X_{i h j k}$ includes child and household demographic characteristics. Specifically, the set of characteristics includes those variables listed in Table 2. ${ }^{8}$ The indicator variable $T_{j}$ is set to one if the selection algorithm designated the child's village for the BRIGHT program, and $f\left(\right.$ Rel_Score $\left._{\mathrm{j}}\right)$ is a polynomial expansion in the relative score of the village. Since the MoE assigned the treatment at the village level, we cluster by village using the standard Huber-White estimator.

As in Kazianga et al. (2013), we find the score variable uncorrelated with most outcomes. This allows for the use of a low-ordered polynomial. Following the previous paper, we use a quadratic specification as our preferred one and use other orders in robustness checks. All the results are

\footnotetext{
${ }^{8}$ For parsimony, we have consolidated some of the control variables into the indexes presented in Table 2. However, the results are invariant to including the individual components of the index instead.
} 
robust to polynomials of other orders. Additionally, because the coefficients on the score variables are so small, we measure the relative score variables in units of $10,000 .^{9}$

Finally, we conduct an additional robustness check for our main outcomes (assignment to BRIGHT II, enrollment, and total test scores) in which we estimate the location of the discontinuity using the estimation technique proposed by Card, Mas, and Rothstein (2008) and Hansen (2000). The technique involves estimating the following model for all values of $\alpha_{1}$ in the range of Rel_Score $e_{\mathrm{j}}$

$$
y_{i h j}=\alpha_{0}+\alpha_{1} I_{\left(\text {Rel_Score }_{j} \geq a\right)}+\varepsilon_{i h j} .
$$

For each estimate, we calculate the $R^{2}$ statistic, and calculate the maximand. These estimates are presented graphically in Figures 1, 2, and 3.

\section{Data Collection}

The survey was fielded in the spring of 2012, i.e. exactly four years after the survey of BRIGHT I discussed in Kazianga et al. (2013), and consisted of a household and a school survey. The household sampling frame comprised all households within the 290 villages (out of the original 293 villages) that applied to the program, including all of the villages in the participant and comparison groups for this study. In each of the sampled villages, interviewers conducted a census to identify households with school-age children between 6 and 17 years old. In each village, 36 households were randomly selected from the list generated from the census. This yielded 10,507 households and 26,430 children between 6 and 17 years old. ${ }^{10}$

The school survey included all schools in sampled villages and schools located within 10 kilometers of the sampled villages that children from the household survey reportedly attended. A total of 332 schools were included in the sample.

Two separate survey instruments were administered to households and schools. The household survey included questions on households' characteristics and possessions, children’s educational outcomes (such as enrollment and attendance), parents’ perceptions of education, anthropometric

\footnotetext{
${ }^{9}$ The details of the scoring formula are available in Kazianga et al. (2014).

${ }^{10}$ A total of 25,291 children took the math assessment and 23,613 children took the French assessment. The number of children taking the test is smaller than the total number of children in the sampled households because administering the tests required face-to-face meetings with the children, and some children were not available.
} 
measurements for children, and the extent to which any children in the household worked. Anthropometric measurements included child height, weight, and upper arm circumference. Finally, math and French tests were administered to all children ages 6 to 17 who lived in the households interviewed in the household survey, regardless of school enrollment. A total of 25,291 children took the math assessment and 23,613 children took the French assessment. These tests were administered immediately after the household survey.

The school survey collected information on the schools' physical infrastructure and supplies as well as school personnel characteristics. Interviewers collected attendance and enrollment data for children who were enrolled in the school. The enumerators used the information provided by parents in the household survey to track and verify that students are effectively enrolled. The school survey was administered during the same period as the household questionnaire, allowing interviewers to visually confirm attendance of household children.

\section{Internal Validity}

\section{A. Treatment Differential}

We demonstrate in Kazianga et al. (2013) that the assignment algorithm generates a sharp 87.4 percentage point difference in the probability that a village participates in the BRIGHT I program, despite the minor level noncompliance described in the previous section. In Table 1, we demonstrate that a similar discontinuity exists in the probability that villages participate in BRIGHT II. Using our preferred specification in column two, we find a difference of 88.4 percentage points. These estimates are consistent when estimated using higher or lower ordered polynomials (columns 2 through 4), allowing the polynomial coefficients to differ by BRIGHT assignment (column 5), and using a probit model (column 6).

We illustrate the results graphically in Figure 1, focusing on the narrow range of $(-250,250) .{ }^{11}$ The solid line in the figure provides estimates from a local linear regression with a bandwidth of 60 and an Epinechnikov kernel, and it is consistent with the estimates from Table 1. The dashed line

\footnotetext{
11 The full range of the relative score is (-924, 3,741). This is slightly different than the range in Kazianga et al. (2013) due to the inclusion of the small number of villages that could not be surveyed in 2008 .
} 
presents the estimated $\mathrm{R} \wedge 2$ statistics from equation (2). As expected, the value of the maximand is less than 0.01 , which is consistent with the discontinuity occurring at zero.

\section{B. Continuity}

In addition to the treatment varying discontinuously, the other critical identification assumption in a regression discontinuity design is that all characteristics not influenced by the treatment do not vary discontinuously. In Kazianga et al. (2013), we demonstrate both that the distribution of villages (using the test suggested by McCrary [2008]) and the socio-demographic characteristics of children do not vary discontinuously at the cut-off point. However, in the four years since the last survey, differential migration could result in the emergence of discontinuities in household or child characteristics.

To provide evidence on the continued reasonability of the continuity assumptions, Table 2 provides the estimated discontinuities for the socio-demographic variables in our current survey using equation (1) without the socio-demographic controls. ${ }^{12,}{ }^{13}$ Of the 16 estimates tested, all are practically small, and only three are statistically significant at conventional levels. ${ }^{14}$ To check the magnitude of the estimated differences, we regress our two main outcomes, enrollment and test scores, on the set of control variables, and estimate the cross product of this vector of coefficients and a vector containing the estimated discontinuities in Table 2. This provides a net estimate of the potential bias resulting from the observed discontinuities. Both are very small, particularly relative to the observed treatment effects (column 1 of Tables 4 and 5). For enrollment, we estimate the projected bias to be 1.2 percentage points and 0.031 standard deviations for enrollment and the total test score respectively. ${ }^{15}$

\footnotetext{
${ }^{12}$ The estimates include department fixed effects.

${ }^{13}$ The discontinuities for the individual variables in the indexes presented in Table 2 are provided in Table A1 in the Appendix.

${ }^{14}$ The sample size is large enough that a joint test of all of the discontinuities using seemingly unrelated regressions yields a Chi ${ }^{2}$ statistic of 34.49 ( $\mathrm{p}$-value is 0.0047) despite the size of the estimated discontinuities.

${ }^{15}$ The individual estimates for this calculation are provided in Tables A2 and A3 of the Appendix.
} 


\section{Estimated Differences in School Infrastructure}

Given that we have an internally valid research design, we finally estimate the effects of assignment to the BRIGHT program on the educational infrastructure experienced by children in the villages. This allows us both to characterize the treatment and assess whether the characteristics of BRIGHT schools have been sustained. ${ }^{16}$ We provide these estimates in Table 3 using data from the household and school surveys. ${ }^{17}$ Except for the probability that a village has a school, which includes all villages, the sample for all estimates includes only those villages with primary schools. Similarly, we estimate the effect on the probability of having a primary school at the village level but estimate effects on the remaining variables at the school level. ${ }^{18}$ All estimates are performed using equation (1) with only department fixed effects. We cluster the standard errors for the school level estimates by village. Columns 2 and 4 provide the treatment effect estimates and columns 1 and 3 provide the limit at the discontinuity for unselected villages. We estimate these using the same specification as the discontinuity estimates but without department fixed effects.

The estimates show that seven years after the start of BRIGHT I and the implementation of BRIGHT II, villages selected for the BRIGHT program still have significantly better educational infrastructure than unselected villages. First, Panel A demonstrates that BRIGHT villages have better access to schools. Villages are still 9.8 percentage points more likely to have a school, but this is a significant reduction from the 31.5 percentage points difference that existed in 2008 (Kazianga et al. 2013). This pattern suggests that unlike the evaluation of BRIGHT I, the effects observed in the current analysis are primarily driven by differences in the characteristics of the schools rather than their presence. However, BRIGHT schools are more accessible. Families are 5.4 percentage points more likely to report the existence of a direct route to the school and estimate that the travel time is 7.8 minutes less than the 29 minutes it takes to get to schools in nonselected villages.

In addition to being more accessible, the BRIGHT villages are also of better quality. They have both more programs and better resources. Starting with Panel B, we find that schools in BRIGHT villages have been open longer, are less likely to report having excess demand, and offer more

\footnotetext{
${ }^{16}$ For reference, these estimates are provided in Tables A2 and A3 of the Appendix.

17 Estimates for a range of other variables including those including in the teacher quality and classroom quality indexes are provided in Appendix Tables A4-A6. The estimates are consistent with those in Table 3.

18 Data from the household surveys is aggregated to the school level.
} 
grades than schools in unselected villages. As expected, the average schools in selected villages go through about the sixth grade, while other schools average almost one grade level less. The estimates in Panels $C$ then show that selected villages also have a larger number of usable classrooms, better quality classrooms, teacher accommodations, dry rations programs for all children, and a better supply of desks and textbooks.

Schools in selected villages also have more teachers. In Panel D, we find that schools in selected villages have more teachers ( 2.5 more per school) and student teacher ratios that are 5.9 students per teacher smaller than schools in unselected villages. In terms of quality, the lack of differences in the qualifications index indicates that the quality of the teachers in selected villages is similar to those of other teachers. The individual components of the index are provided in Table A7. All of the estimates for the individual components suggest few differences in teacher quality except a small difference in experience where teachers in selected villages are slightly (5.6 percentage points) more likely to have more than 10 years of experience. This is notable because in 2008, the teachers in selected villages were more likely to be new teachers with less than five years of experience. So, the quality of teachers has increased in the last four years. This is likely due to the natural transitions between teachers because teachers can request a transfer after three years at the same school.

As we describe above in Section II, an important part of the BRIGHT facilities is the incorporation of "girl-friendly" characteristics designed to target the enrollment of girls. In Panel E, we show that four years later, schools in selected villages have not only sustained these characteristics they have, with one exception, improved relative to the schools in unselected villages when compared to 2008 with one exception. For each of the characteristics except for sensitivity training, selected schools are 34 to 58 percentage points more likely to have each amenity. These differences are much larger than in 2008, despite schools in unselected villages also improving significantly along each margin except dry-rations programs for girls where they remain at the 2008 level. ${ }^{19}$ The one exception, however, is gender sensitivity training where the difference in 2012 is only 16 percentage points compared to 50 percentage points in 2008. Because the levels of training in the

\footnotetext{
${ }^{19}$ It is important to note that although the estimates in Table 3 are estimates of the limit for unselected villages, the estimates provided in Kazianga et al. (2013) are averages for all unselected villages. Although the estimates are all very similar, we provide the unselected limits for each in Table A7 of the Appendix.
} 
unselected villages are roughly the same, the problem is that selected villages have fewer teachers who have received the training. ${ }^{20}$

Finally, even if schools have better characteristics, there is always the question of whether families are sufficiently aware of the differences that change enrollment decisions. We collected data on some characteristics from both households and school administrators. This includes whether schools have gender segregated latrines, a canteen, a feeding program, dry rations, and a preschool. This allows us to check parents' awareness by comparing the estimated differences. The household-based estimates are in Table A4 of the Appendix and they are remarkably consistent with the estimates in Table 3, suggesting that parents are aware of the better characteristics available in selected village schools.

\section{Academic Outcomes}

We start by analyzing the effects of BRIGHT on overall enrollment. The treatment effect estimates created using equation (1) are presented in Table 4. We start with students' self-reported enrollment. Using our preferred quadratic specification with full controls, we find in column 1 that being selected for the BRIGHT program increases children's probability of being enrolled by 15.5 percentage points. In columns 2 through 7, we vary the specification, estimating the effects without controls $^{21}$ (column 2), with a linear polynomial (column 3), with a cubic polynomial (column 4), allowing the quadratic polynomial coefficients to differ with the discontinuity (column 5), using a probit model (column 6), and using our verified enrollment measure (column 7). All of these estimates are consistent with or preferred estimate. ${ }^{22}$ The net result of these higher enrollment rates is that, on average, children in villages selected for the BRIGHT progress 0.68 more years in school.

\footnotetext{
${ }^{20}$ There is no evidence of gender sensitivity training for teachers in the second phase. Thus, teachers who received the training may have left.

${ }^{21}$ In particular, it is important to note that the similarity of the estimates with and without controls reinforces the internal validity of the research design.

${ }^{22}$ The verified enrollment estimates are lower than the preferred estimates. However, this difference likely results from the differential measurement error inherent in the verification process as described in Section 3.C. In spite of this downward bias on the treatment effect, however, the estimate does support the existence of a large effect on enrollment.
} 
Table 5 presents the estimated effects on test scores. Again, the preferred specification presented in column 1 shows a large, positive average effect of the BRIGHT program on test scores. Students living in villages selected for the BRIGHT program score 0.29 standard deviations higher than students in unselected villages. Again, the estimated effect is consistent across the same range of specifications we used for the enrollment outcomes. In the Appendix (Tables A9 and A10), we demonstrate that the observed treatment effect is consistent across both the math and language sections of the exam and across many of the specific competencies. We also provide unstandardized treatment effect estimates using the percentage of correct answers for each subject and the aggregate scores.

Finally, Figures 2 and 3 provide graphical depictions of the estimated treatment effect on the narrow range of $(-250,250)$. The depicted discontinuities in each are consistent with the estimates in Tables 4 and 5. Additionally, the estimates of the fit of different discontinuities are maximized at a point that is less than 0.01 , consistent with a discontinuity at zero.

To better understand the underlying causes of these effects, we disaggregate the estimates by age. Figure 4 presents the estimated treatment effects for enrollment (left axis) and total test score (right axis) by age. For each age, we provide the estimated treatment effect and the 95 percent confidence band. The enrollment effects are surprisingly consistent for all children despite the fact that the BRIGHT schools end at grade 6. This is consistent with the wide age distributions of students enrolled in all of the schools. The effects on test scores, however, are not consistent. Older children have much larger treatment effects than younger children.

We explore two possible explanations for the heterogeneity by age. First, as we showed in the previous section, schools in selected villages are older and have more grade levels than other schools. So, students in selected villages may simply be mechanically further along in primary school than students in unselected villages. However, this does not seem to be the case. Figure 5 provides estimates of the probability that children have completed primary school grades. If the observed effect had resulted from the fact that children had just had an opportunity to progress further in selected villages, we would expect larger treatment effects on later grades. However, this is not the case. The observed effects seem reasonable when compared to the effects from the 2008 survey (right axis), but the treatment effect is decreasing in grade level. 
The effect does, however, seem to be related to grade progression. Figure 6 provides estimates of the highest grade achieved by age, along with the test score effects from Figure 5 for reference. The treatment effects line up very closely. Finally, if grade progression does explain the variation in observed test score effects, then one would expect that controlling for the highest grade achieved would explain much of the observed test score treatment effect presented in column 1 of Table 5. These estimates are presented in the first two columns of Table 6. Using either fixed effects (column 1) or including the variable as a linear control (column two), grade progression, in fact, explains the entire test score treatment effect. This is not the case for the two mechanical explanations. The final four columns contain similar estimates controlling for the number grades available to students or the number of years that a village has had a school, but neither explains any of the observed treatment effects.

To understand why students in BRIGHT schools progress further, we compare the types of students in schools in selected and unselected villages. The differences, of course, are not internally valid treatment effects, but they do offer suggestive evidence of possible bases of the observed effects. ${ }^{23}$ Table 7 provides estimates at the discontinuity of different measures of the relationship between grade progression and age. Each estimate is constructed using equation (1) with and without controls for villages with schools using children currently enrolled in school.

In Panel A, we estimate differences in measures of students' age relative to their grades. First, we show that only 35.9 percent of students in unselected villages can be considered age appropriate for their grade. ${ }^{24}$ The proportion in selected villages is 8.5 percentage points higher. The next two rows show that the underlying reason is that students are too old rather than too young. If we estimate the number of years that children are "off-grade", students in unselected villages are on average 1.26 years off while students in selected villages are about a quarter of a year closer to being the right age for their grade.

In Panel B, we show that the reason for this pattern is that students seem to be more likely to start school younger-closer to the appropriate age. The first two rows show that children-selected villages are more likely than other students to start school on time, and on average, start school

\footnotetext{
${ }^{23}$ In fact, the observed effects on enrollment (Table 4) and the probability that a village has a school (Table 3) strongly suggest that the comparison lacks internal validity.

${ }^{24}$ Students are expected to start first grade at age 7. So, students are classified as age appropriate if their age is within a year of their grade plus six.
} 
overall at a younger age. The remaining columns show that other determinants of grade progression are not likely factors. There is no difference in the probability that children skipped a grade, experienced a break in schooling, or changed schools. There is a difference in grade repetition, but this works in the opposite direction with students in selected villages more likely to have been held back. ${ }^{25}$

It is important to note that these results suggest that although access to high-quality schools can be extremely beneficial; they alone are insufficient to ensure that a large percentage of students complete primary school. These schools are effective at getting children into school. They also seem to get children to start school at the right age and keep them in for longer periods of time. However, even selected villages have low enrollment rates. For example, only 51 percent of primary school aged students (ages 6-12) are currently enrolled in school. Additionally, as the declining treatment effects in Figure 5 demonstrate, keeping students in school once they have started is a challenge for all schools, even if BRIGHT schools may have a comparative advantage.

Finally, an important question is whether the BRIGHT schools have been able to sustain the large impacts observed in 2008. However, both the current sample and tests are more expansive that the previous ones, including both older children and a wider variety of test questions. To estimate equivalent treatment effects, we restrict the current sample to the same set of students surveyed in 2008 (ages 6 through 12) and estimate the effects on test scores using only those competencies included on the 2008 exams. ${ }^{26}$ First, the effect on enrollment for these children has fallen from 18.5 percentage points to 14.9 percentage points. This small decline is likely due to the increase in the presence of schools in unselected villages, and is in line with previous estimates of the likely effect of the increased presence of schools in unselected villages. ${ }^{27}$ The test score effect declined during this period from 0.41 in 2008 to 0.23 in 2012, but comparing test scores is more difficult

\footnotetext{
${ }^{25}$ Teachers and administrators of individual schools make the decision about whether or not children progress to the next grade. There is no standardized criteria or higher administrative unit that makes these decisions. Because students in selected schools do have higher test scores on average, it may be that BRIGHT schools are setting higher promotion standards than other schools. This could be another source of the quality difference in the two types of schools.

${ }^{26}$ The competencies for the current tests are listed in Tables A9 and A10 in the Appendix. The tests administered in 2008 were much shorter. The tests included only number identification, counting, greater-than/less-than, and single digit addition and subtraction on the math test. The language test included letter identification, reading simple words, and fill-in-the-blank in sentences.

${ }^{27}$ For example, in Kazianga (2013), we estimated that placing a non-BRIGHT school in a village caused an increase in enrollment of 26.5 percentage points. In the intervening four years, the difference in the probability that a selected village had a school dropped by 21.7 percentage points, implying that we should expect a decline in the treatment effect by 5.8 percentage points, which is a bit larger than the observed decline in the effect.
} 
because they are a function of more than enrollment. They are a function, for example, of both the duration of enrollment or the highest grade achieved. However, like the results presented above for the 2012 survey, we find that the treatment effect on test scores in the 2008 survey is also entirely explained by the highest grade a child achieves, suggesting that the BRIGHT schools may still be as productive relative to other schools as they were four years ago. ${ }^{28}$

\section{Secondary Outcomes}

\section{A. Health}

As shown in Table 3, schools in selected villages are more likely to have feeding programs and preschools, and even absent the greater availability of the programs, children are more likely to be enrolled and have access to them. This raises the possibility that the program may have affected children's health. We assess this possibility in Table 8. However, the data suggest that the program has had no effect, likely due to low school enrollment levels.

First, we use the anthropometric measures described in Section III.C to assess directly whether being selected for the BRIGHT program improved students' growth. Across all outcomes, we find no effect. Some care is required in evaluating the individual treatment effects because as described in detail in the table notes, some of the measures are only available for a subset of the children. However, for each of the measures that are only defined for a restricted sample, we reestimate the treatment effects for the less restrictive measures on the smaller sample in Panel A of Table A11 of the Appendix. None of the estimated treatment effects is statistically significant at conventional levels. ${ }^{29}$

To investigate the lack of an effect, we estimate the child level treatment effects on participation in the programs in Panel B of Table 8. Children are participating in the programs. Children living in a village selected for BRIGHT are more likely to participate in school feeding programs, participate for longer periods of time, and attend schools that offer dry rations programs.

\footnotetext{
${ }^{28}$ This is true if we include highest grade achieved linearly or as fixed effects. Results are available upon request.

${ }^{29}$ There are also a few clear outliers in the data. So, we also check the robustness of the results by estimating the treatment effects while excluding outliers. These results are presented in Panel B of Table A11 in the Appendix. Except for one outcome, we find no effects for each measure estimated on each subset of the data. Because this is the only treatment effect estimate of 29 to be statistically significant, this is likely a spurious result.
} 
However, when we look at consumption of food within the household in Panel C of Table 8, we find no increases in the total amount of food consumed. The measure is, of course, because it asks only whether a family member consumed the indicated food in the last two weeks rather than measuring quantities, ${ }^{30}$ but it is consistent with the observed lack of effects on children's growth. The lack of an effect on sorghum and millet is particularly surprising because these are the grains distributed in the dry rations program. This pattern can be, however, explained by the observation that millet and sorghum are two of the most common staples, and therefore most households are likely to have eaten these staples in the last two weeks.

These results are in contrast to existing studies documenting the effectiveness of such programs (such as Kazianga, de Walque, and Alderman 2014). The reason may be that although we observe differential levels of participation in Panel B of Table 8, the magnitudes are small. Children in selected villages are only 17 percentage points more likely to participate in a school feeding program than the 23 percent of children participating in unselected villages. The net effect is an additional 0.8 days in the program in addition to the day a week that students in unselected villages spend in feeding programs. The treatment differential is a bit larger for dry rations programs with children in selected villages being 30 percentage point more likely to attend a school with such a program (and this difference seems largely to be due to programs targeted at girls), but because only 6.6 percent of children in unselected villages participate in these programs, the total number of children attending a school with a dry rations program is still low. The main cause of these low participation rates is the low overall enrollment rates. If, for example, we estimate the participation rates for enrolled children only, the estimates are much higher: 75 percent participation in feeding programs in unselected villages with a 12.4 percentage point differential for selected villages, and 19 percent participation in dry rations programs with a 58 percent differential in selected villages. ${ }^{31}$ This suggests that the best strategy for generating effects on children's health may be to focus on further improving enrollment.

\footnotetext{
${ }^{30}$ We ask about all family members because evidence exists that take-home rations change the allocation of food within the household and affect other family members (Kazianga, de Walque, and Alderman 2014).

${ }^{31}$ Estimates available upon request.
} 


\section{B. Child Work}

Attending school requires students not to engage in other activities during the time that they are in class or studying. One of the main opportunity costs is work that the child might otherwise do for pay or for the family. Analysis of the data from the 2008 survey found no effect of the program on children's work (Kazianga et al. 2013). ${ }^{32}$ We assess the effects of the program using the later data set on the same set of outcomes in Table $9 .{ }^{33}$ In contrast to the earlier results, we find that the program modestly reduced the number of children engaged in each activity by 2.5 to 5.9 percentage points. Given the fraction of children engaged in these activities in control villages, this represents an average 9.2 percent relative decrease across all measures. Compiling the outcome into a standardized composite work index, we find a reduction of 0.14 standard deviations.

The increased school attendance documented above displaces child labor only modestly. Presumably, even when children are enrolled in school, they still engage in some form of child work, especially the tasks that are compatible with school hours. For instance, Kazianga, de Walque and Alderman (2012) document how an increase in enrollment in rural Burkina Faso due to a school feeding intervention did not reduce children participation in household chores. Similarly, Kondylis and Manacorda (2012) find that school proximity in rural Tanzania increases school attendance but has not significant effects on child labor.

\section{Heterogeneity}

\section{A. Heterogeneity by Gender}

A key component of the BRIGHT program consists of services targeting girls' enrollment. As a result, we investigate whether the program had differential effects on girls in Table 10. Consistent with the significant improvements in girl-friend infrastructure observed in Section IV.C, we find that in the intervening four years, the program has become much more successful at targeting girls.

\footnotetext{
${ }^{32}$ It should be noted that de Hoop and Rosati (2014) find conflicting results, arguing that the program actually increased children's work in some specifications using the same data.

${ }^{33}$ The outcomes presented in Table 9 are limited to those in which at least 10 percent of children report participating. We present the results for rarer forms of child work in Table A12 of the Appendix. We find no effect of the program on these other measures. However, the effect on the aggregate work index is robust to the inclusion of these other measures.
} 
We disaggregate the effects by interacting the indicator for whether a village was selected with an indicator set to one if the child is female.

We find that the program had significantly larger effects on girls than boys. Girls' enrollment increased by 11.3 percentage points more than boys, and their test scores increased by 0.21 standard deviations more. In total, girls reached 0.45 higher grade levels than boys, more than eliminating the existing disparities in test scores and grade progression. These results are larger than the differentials observed in the 2008 survey where we estimated a 4.7 percentage point differential in enrollment for girls and found no difference in the effects on test scores.

These results have two important implications. First, the BRIGHT program more than eliminates the gender gaps in education in a relatively short period of time-about seven years, thus demonstrating how to achieve one of the priorities of the Millennium Development Goals. Second, the impacts of BRIGHT on learning outcomes (particularly in math) contrast with the evidence of gender gaps in test scores (particularly in math) documented in both high and low income countries (Bharadwaj et al. 2015; Dickerson, McIntosh and Valente 2010; Fryer and Levitt 2010), and suggest that within the right environment girls perform at least as well as boys in test scores, including language and mathematics (e.g., Muralidharan and Sheth 2015).

Because many of the dry rations programs are also targeted at girls, we might also see larger effects for girls' growth. We assess this in Panel B, but as with the overall results, we find no differences by gender. Additionally, because the dry rations were likely consumed by the entire family, we also estimate differences in treatment effects for children who live in a household that includes a school-aged girl as well as estimate differential effect by the number of school-aged girls. We find no effect or differential effects for these specifications either. As with the overall results, these are likely explained by the low overall enrollment rates. ${ }^{34}$

There are also likely to be differential effects on child work given that girls are much more likely than their brothers to do household work and that some components of the BRIGHT schools focus on facilitating the enrollment of girls with specific household responsibilities. The preschools, for example, were designed to allow girls who had to tend to their younger siblings to attend school. These estimates are presented in Panel C. We find differential effects in the probability that girls

\footnotetext{
34 These results are available upon request.
} 
collect firewood and clean, and despite the null effects on the other outcomes, we find an overall reduction in the work index of 0.11 standard deviations. Thus, the BRIGHT schools reduced the number of children engaged in these activities overall, and also succeeded in further reducing the rates for girls. ${ }^{35}$

\section{B. Heterogeneity by grade}

The analysis of the individual components of the math and French tests broken down by grade level is provided in Tables A9 and A10 of the online Appendix. In Table A9, columns 1 and 4 show the percentage of correct answers to the math tests and the standardized scores of the math tests in nonselected villages, respectively. columns 2 and 4 show the estimated effect of BRIGHT on each given characteristic, using the percentage of correct answers (column 2) and the standardized test score (column 4).

Starting with the percentage of correct answers, we find that the program increased the math scores at all grades and across all individual components of the tests. The program increased the test scores by 0.81 percentage points in first grade, by 0.85 percentage points in second grade, and by 0.46 percentage points in third grade. The test scores by individual components increased from 2.4 to 13.7 percentage points in first grade, from 7.2 to 11.6 percentage points in second grade and from 4.0 to 4.9 percentage points in third grade. Given the percentage of correct answers in control villages, the estimates correspond to an average 16.7 percent relative increase in first grade, 66.7 percent increase in second grade, and 82.1 percent increase in third grade. Hence, the relative gains in math increase with the grade levels, suggesting that the program effects accumulate through the grades.

In column 5, we demonstrate that the standardized test score for students living in villages selected for the BRIGHT program score 0.26 standard deviations higher than students in unselected villages overall. Again, the estimated effect is consistent across all the sections of the tests and across all grades.

\footnotetext{
${ }^{35}$ Given the availability of the preschools, we also estimate a triple interaction in which the treatment effect and gender variables in Panel C are further interacted with the number of children under the age of 6 and an indicator for whether or not there are children under the age of 6 in the household. We find no differential effects for either measure of young children in the household. These results are available upon request.
} 
We report the French test scores in Table A10, and the layout is similar to Table A9. Starting with the percentage of correct answers, we find that in first grade, the program raised the test scores between 9.1 and 13.8 percentage points. In second grade, the test scores increased by 11 percentage points for "letter identification with accents" and by 10.1 percentage points for "matching word to picture”. In third grade, the scores increased by 4.9 to 6.3 percentage points. The program effect is consistently positive across all competencies and all grade levels. The relative increase in the percentage of correct answers is 53: 5 percent for first graders, 67.5 percent for second graders and 93 percent for third graders. The pattern of increasing relative gains in grade levels virtually matches the pattern observed for the math tests. Combining all test components and all grades, we a relative increase of 64.1 percent.

The standardized test scores are shown in column 5. The test scores in selected villages increased by 0.30 standard deviations in first grade, by 0.27 standard deviations in second grade and by 0.22 standard deviations in third grade. The combined effect is 0.30 standard deviations for all grades and test components. These gains are also consistent across grades and individual test components.

\section{Conclusion}

The preceding analysis demonstrates the long-term sustainability of high-quality primary schools with amenities designed to target the enrollment of girls. We find that seven years after the start of the program, children in village selected to receive one of these schools are 15.4 percentage points more likely to be enrolled in school and score 0.29 standard deviations higher on standardized achievement tests. Children of all ages experience similar gains in enrollment, but older children experience larger gains in learning than younger children. These differences in academic achievement between village and children seem to reflect higher levels of grade progression in selected villages among older children. We find no effect on children's growth, but we find modest reductions in children engagement in household work. Reflecting the emphasis on "girl-friendly" amenities, these effects also accrue disproportionately to girls. Girls in selected villages have significantly higher enrollment rates, test scores, and grade progression, and they are less likely to engage in household work. 
These results have important implications for future work. First, as part of the growing research effort into the production function of primary schools, school starting age and grade promotion may be important areas of research. The wide variations of ages that we observe in the primary schools in this study are not unusual. Moreover, it may be that an important part of encouraging children to complete primary school and matriculate at secondary schools is getting students to start school on time. Conversely, although many studies focus on children in the targeted age groups (for example, Burde and Linden 2013), older students may comprise a significant portion of the benefits of primary school programs.

Additionally, although the emphasis on research into school enrollment is shifting to secondary school enrollment in much of the developing world, more research into understanding why families choose not to enroll their children in these poor performing countries may be necessary. Although improved infrastructure seems to be highly effective in improving the enrollment rates of children and, in particular, girls. Infrastructure alone may not be sufficient to bring the remaining countries with low primary school enrollment rates into line with the rest of the developing world. Despite the impressive relative effectiveness of these very well resourced primary schools, the enrollment levels of villages selected for the program average only 47.6 percent. These low participation rates may even limit the effectiveness of add-on programs like the school feeding and dry-rations programs in the BRIGHT schools. 


\section{References}

Alderman, H., Kim, J. and Orazem, P.F., 2003. Design, evaluation, and sustainability of private schools for the poor: the Pakistan urban and rural fellowship school experiments. Economics of Education Review, 22(3), pp.265-274.

Andrabi, T., J. Das, and A. I. Khwaja. "Students today, teachers tomorrow: Identifying constraints on the provision of education." Journal of public Economics 100 (2013): 1-14.

Bharadwaj, P., De Giorgi, G., Hansen, D.R. and Neilson, C., 2015. The gender gap in mathematics: evidence from a middle-income country. FRB of New York Working Paper No. FEDNSR721.

Breierova, L. and Duflo, E., 2004. The impact of education on fertility and child mortality: Do fathers really matter less than mothers? National Bureau of Economic Research. No. w10513.

Burde, D. and Linden, L.L., 2013. Bringing education to Afghan girls: A randomized controlled trial of village-based schools. American Economic Journal: Applied Economics, 5(3), pp.2740.

Card, D., A. Mas, and J. Rothstein. "Tipping and the Dynamics of Segregation." The Quarterly Journal of Economics (2008): 177-218.

Chaudhury, N., Hammer, J., Kremer, M., Muralidharan, K. and Rogers, F.H., 2006. Missing in action: teacher and health worker absence in developing countries. The Journal of Economic Perspectives, 20(1), pp.91-116.

Cuesta, A., Glewwe, P. and Krause, B., 2015. School Infrastructure and Educational Outcomes: A Literature Review, with Special Reference to Latin America. Forthcoming. Economia

De Hoop, J. and F. C. Rosati (2014). “Does promoting school attendance reduce child labor? Evidence from Burkina Faso's BRIGHT project.” Economics of Education Review, 39, 78-96.

Dickerson, A., McIntosh, S. and Valente, C., 2015. Do the maths: An analysis of the gender gap in mathematics in Africa. Economics of Education Review, 46, pp.1-22.

Duflo, E. R. (2001). “Schooling and Labor Market Consequences of School Construction in Indonesia: Evidence from an Unusual Policy Experiment.” The American Economic Review, 91(4), 795-813. 
Filmer, D. (2007). "If you build it, will they come? School availability and school enrolment in 21 poor countries.” Journal of Development Studies, 43(5), 901-928.

Fryer Jr, R.G. and Levitt, S.D., 2010. An Empirical Analysis of the Gender Gap in Mathematics. American Economic Journal: Applied Economics, pp.210-240.

Glewwe, P.W., Hanushek, E.A., Humpage, S.D. and Ravina, R., 2011. School resources and educational outcomes in developing countries: A review of the literature from 1990 to 2010 (No. w17554). National Bureau of Economic Research.

Glewwe, P. and Jacoby, H., 1998. School enrollment and completion in Vietnam: An investigation of recent trends. In: Dollar, D., Glewwe, P., Litvack, J. (Eds.), Household Welfare and Vietnam's Transition. The World Bank, pp. 201-234 Household welfare and Vietnam's transition

Handa, S., 2002. Raising primary school enrolment in developing countries: The relative importance of supply and demand. Journal of development Economics, 69(1), pp.103-128.

Hansen, B. E. (2000). Testing for structural change in conditional models. Journal of Econometrics, 97(1), 93-115.

Kazianga, H., D. de Walque and H. Alderman. (2014) "School feeding programs, intrahousehold allocation and the nutrition of siblings: Evidence from a randomized trial in rural Burkina Faso." Journal of Development Economics 106: 15-34.

Kazianga, H., D. Levy, L. Linden and M. Sloan (2013). "The Effects of "Girl-Friendly" Schools: Evidence from the BRIGHT School Construction Program in Burkina Faso.” American Economic Journal: Applied Economics, 5(3), 41-62.

Kondylis, F. and Manacorda, M., 2012. School proximity and child labor evidence from rural Tanzania. Journal of Human Resources, 47(1), pp.32-63.

Levy, D., M. Sloan, L. Linden, and H. Kazianga (2009). “Impact Evaluation of Burkina Faso's BRIGHT Program.” Final Report. Mathematica Policy Research, Inc.

Mason, A.D. and Rozelle, S.D., 1994. Schooling decisions, basic education, and the poor in rural Java (Doctoral dissertation, to the Food Research Institute. Stanford University). 
McCrary, J. (2008). "Manipulation of the running variable in the regression discontinuity design: A density test." Journal of Econometrics 142.2: 698-714.

Muralidharan, K. and Sheth, K., 2015. Bridging education gender gaps in developing countries: The role of female teachers. Journal of Human Resources.

Murnane, R.J. and Ganimian, A.J., 2014. Improving educational outcomes in developing countries: Lessons from rigorous evaluations (No. w20284). National Bureau of Economic Research.

Newman, J., Pradhan, M., Rawlings, L.B., Ridder, G., Coa, R. and Evia, J.L., 2002. An impact evaluation of education, health, and water supply investments by the Bolivian Social Investment Fund. The World Bank Economic Review, 16(2), pp.241-274.

Pradhan, M. and Rawlings, L.B., 2002. The impact and targeting of social infrastructure investments: Lessons from the Nicaraguan Social Fund. The World Bank Economic Review, 16(2), pp.275-295.

Paxson, C. and Schady, N.R., 2002. The allocation and impact of social funds: spending on school infrastructure in Peru. The World Bank Economic Review, 16(2), pp.297-319.

Theunynck, S., 2009. School construction strategies for universal primary education in Africa: should communities be empowered to build their schools? World Bank Publications. 
Figure 1. Treatment Differential

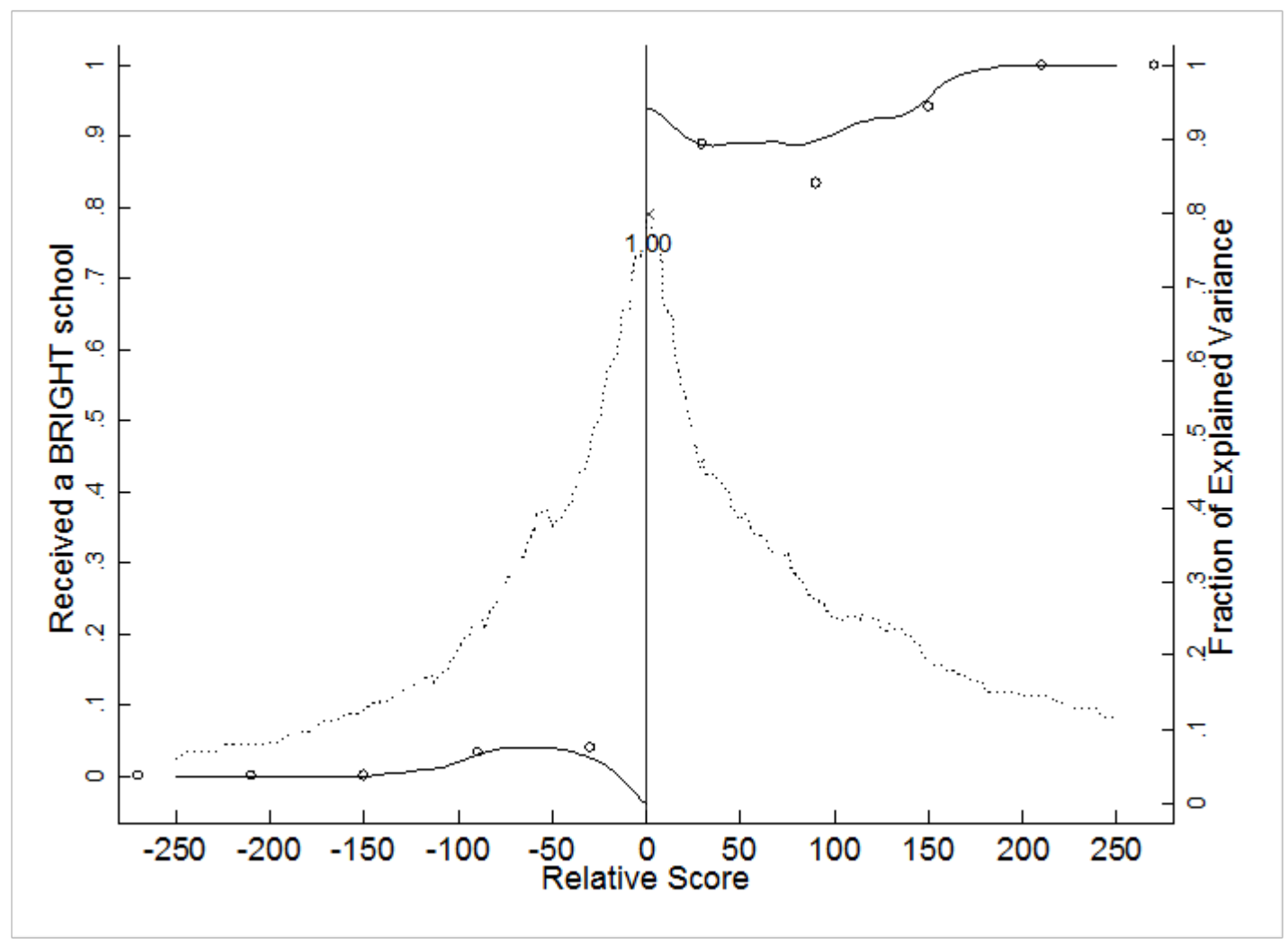

Note: The left vertical axis represents a nonparametric plot of the probability of receiving a BRIGHT school as a function of the relative score. The plot is estimated using a linear local polynomial estimator with an Epanechinikov kernel and a bandwidth of 60 points. The circles represent the average probabilities for 60-point bins. The right vertical axis presents the estimated location of the discontinuity using the procedure described in Section III.B to find the point of discontinuity that maximizes the R2 statistic, indicated by the point "x." 
Figure 2: Effects of Enrollment

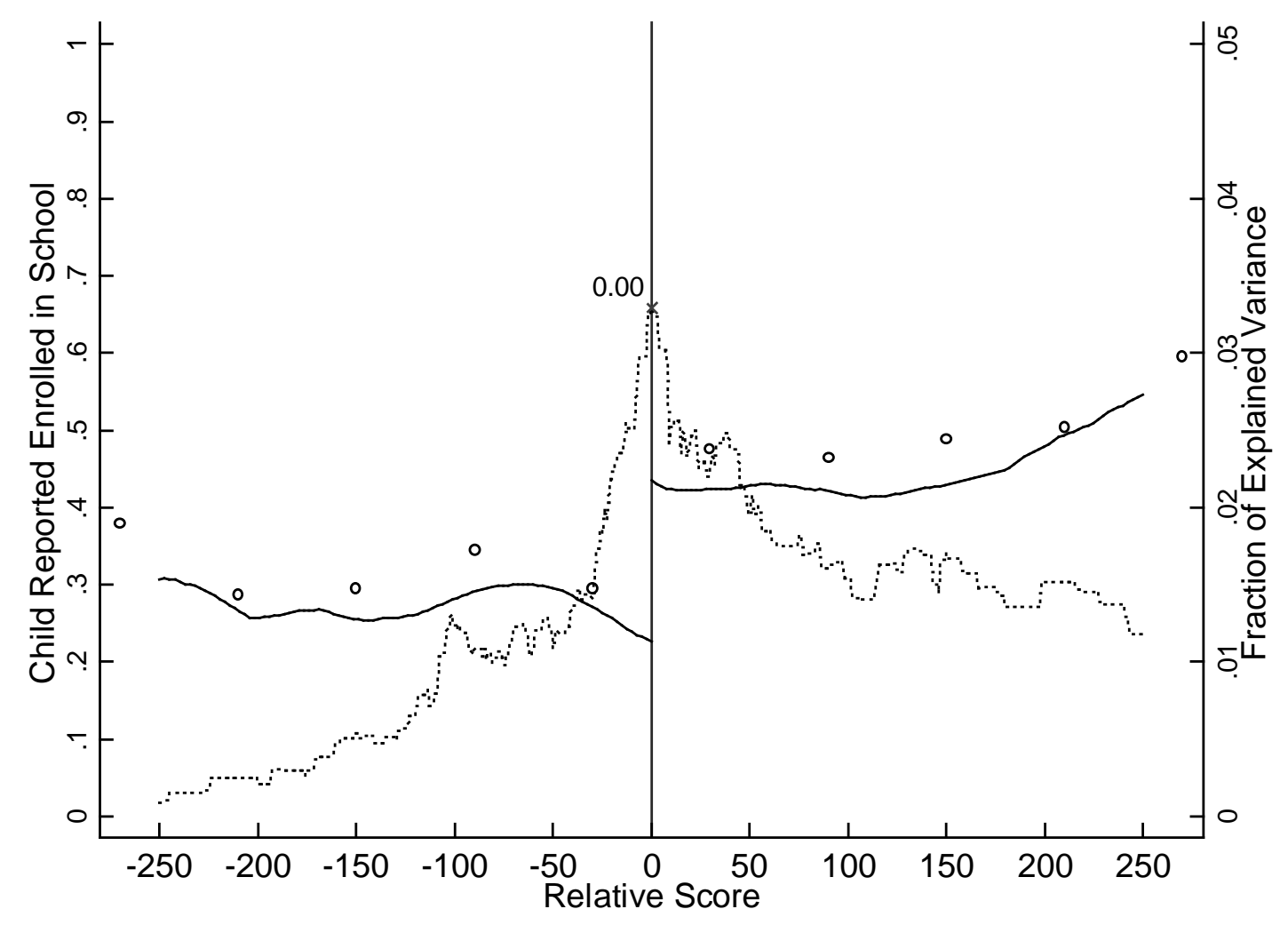

Note: The left vertical axis represents a nonparametric plot of the probability of a child being enrolled in school (according to the head of household) as a function of the relative score assigned to the child's village. The plot is estimated using a linear local polynomial estimator with an Epanechinikov kernel and a bandwidth of 60 points. The circles represent the average probabilities for 60-point bins. The right vertical axis presents the estimated location of the discontinuity using the procedure described in Section III.B to find the point of discontinuity that maximizes the R2 statistic, indicated by the point "x." 


\section{Figure 3: Effects on Test Scores}

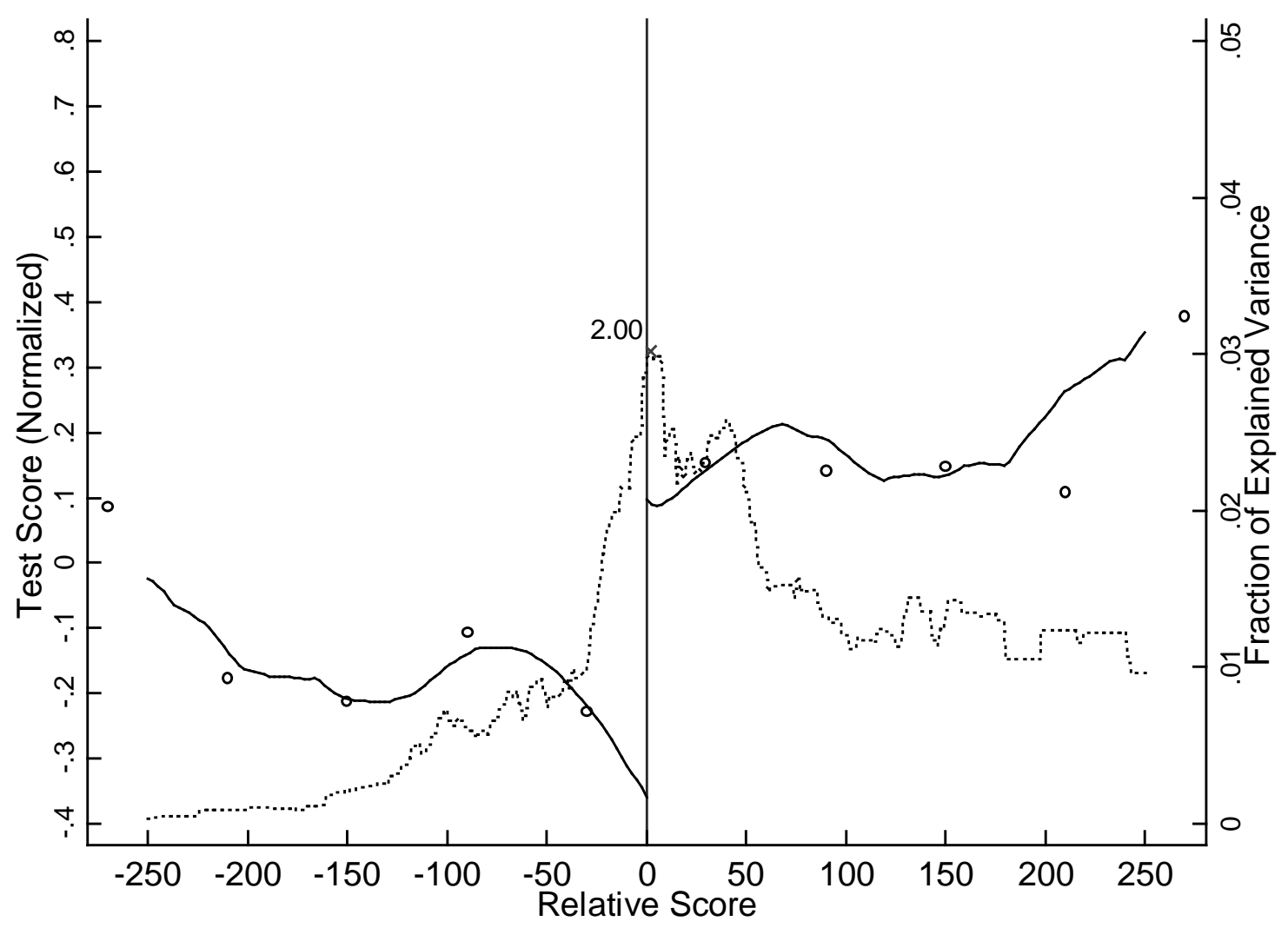

Note: The left vertical axis represents a nonparametric plot of a child's normalized total test score as a function of the relative score assigned to the child's village. The plot is estimated using a linear local polynomial estimator with an Epanechinikov kernel and a bandwidth of 60 points. The circles represent the average probabilities for 60-point bins. The right vertical axis presents the estimated location of the discontinuity using the procedure described in Section III.B to find the point of discontinuity that maximizes the R2 statistic, indicated by the point "x." 
Figure 4: Effects on Test Scores

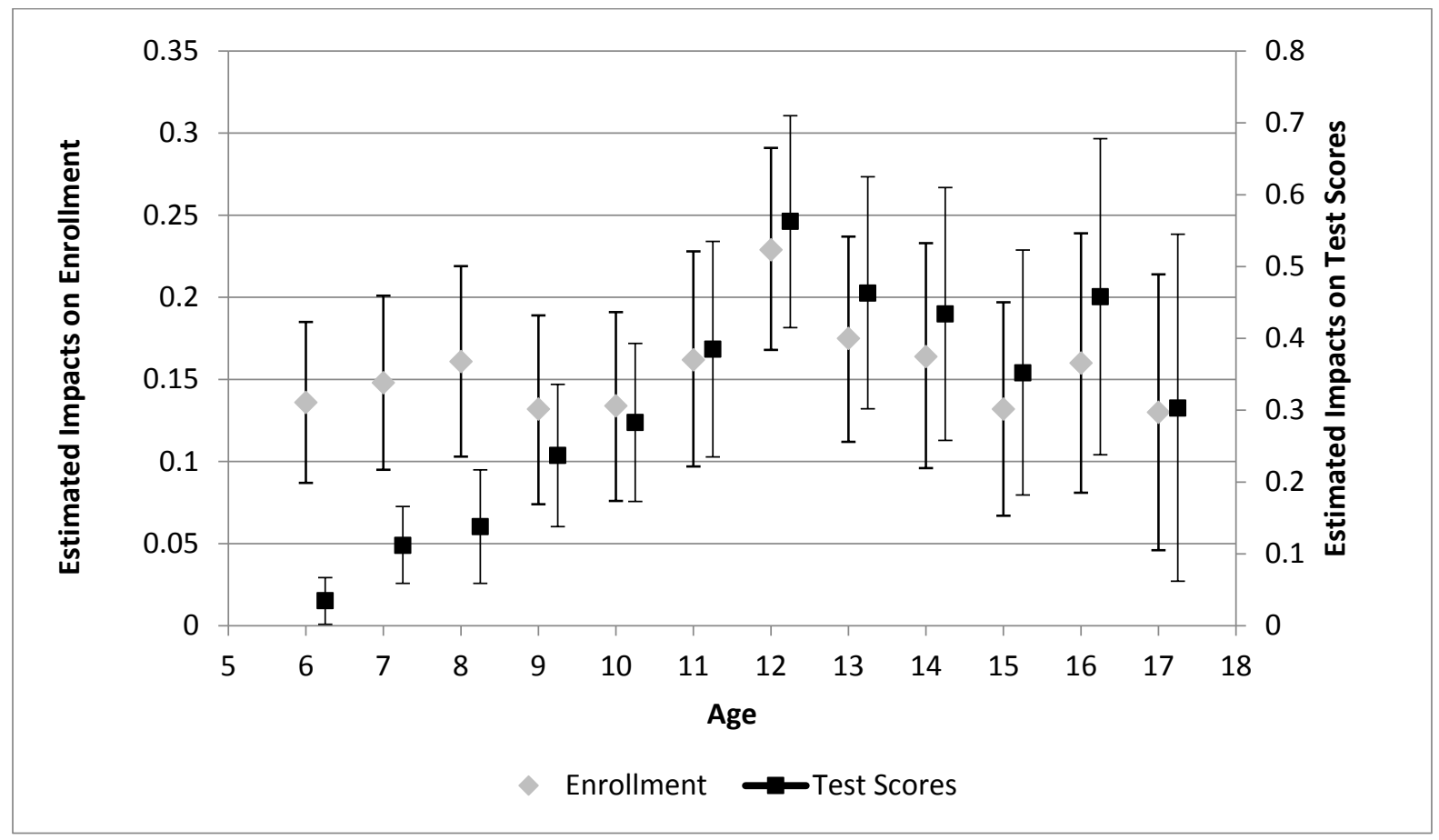

Note: The left vertical axis represents the estimated discontinuity of BRIGHT on enrollment, with triangles indicating the point estimate and a line indicating the 95 percent confidence interval. The right vertical axis represents the estimated discontinuity of BRIGHT on normalized total test score, with squares indicating the point estimate and a line indicating the 95 percent confidence interval estimates. 
Figure 5. Effects on Grade Achievement

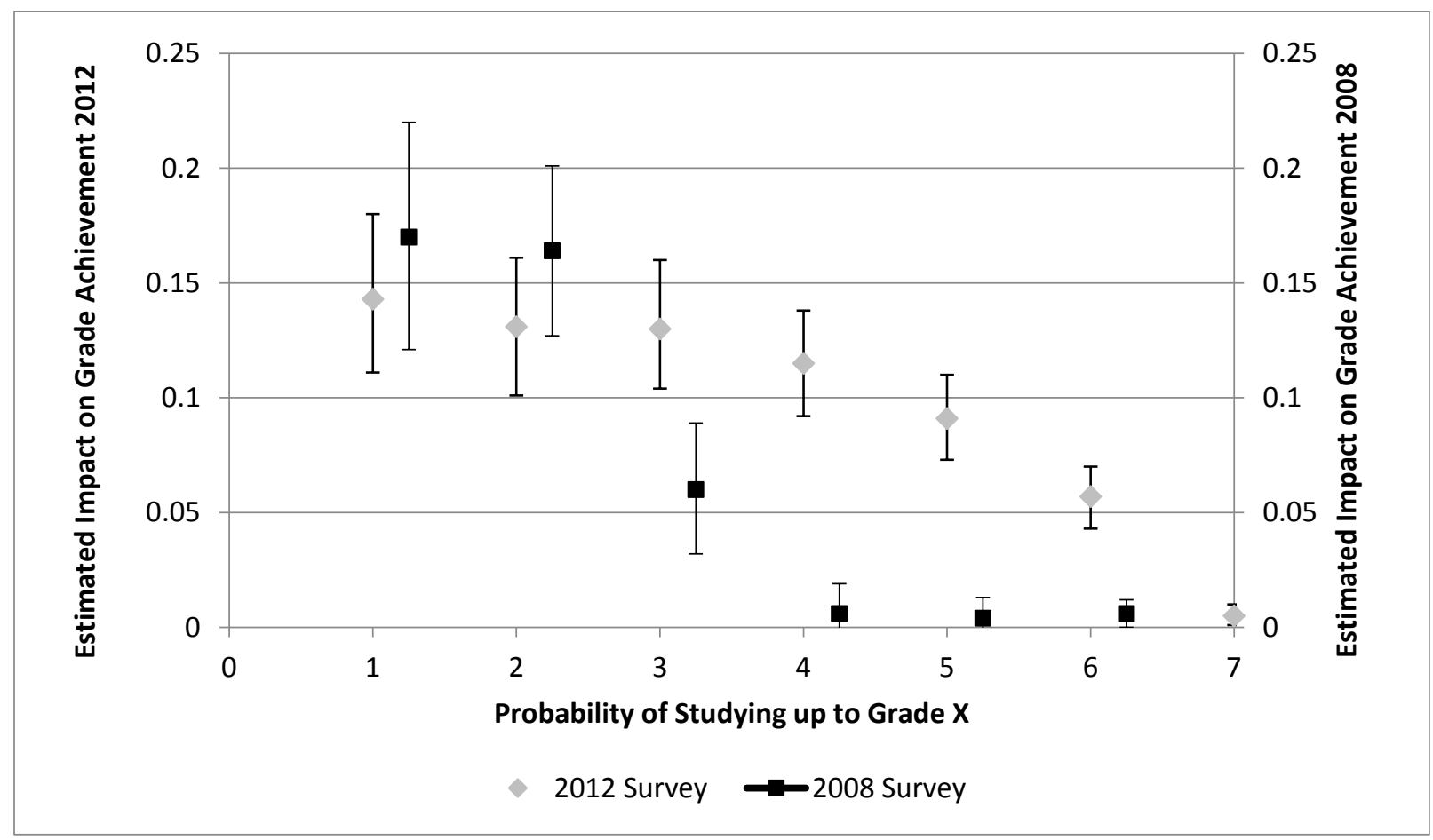

Note: The left vertical axis represents the estimated discontinuity of the probability of studying up to Grade X in the 2012 survey, with triangles indicating the point estimate and a line indicating the 95 percent confidence interval. The right vertical axis represents the estimated discontinuity of the probability of studying up to Grade $\mathrm{X}$ in the 2008 survey, with squares indicating the point estimate and a line indicating the 95 percent confidence interval estimates 
Figure 6: Effects on Test Scores

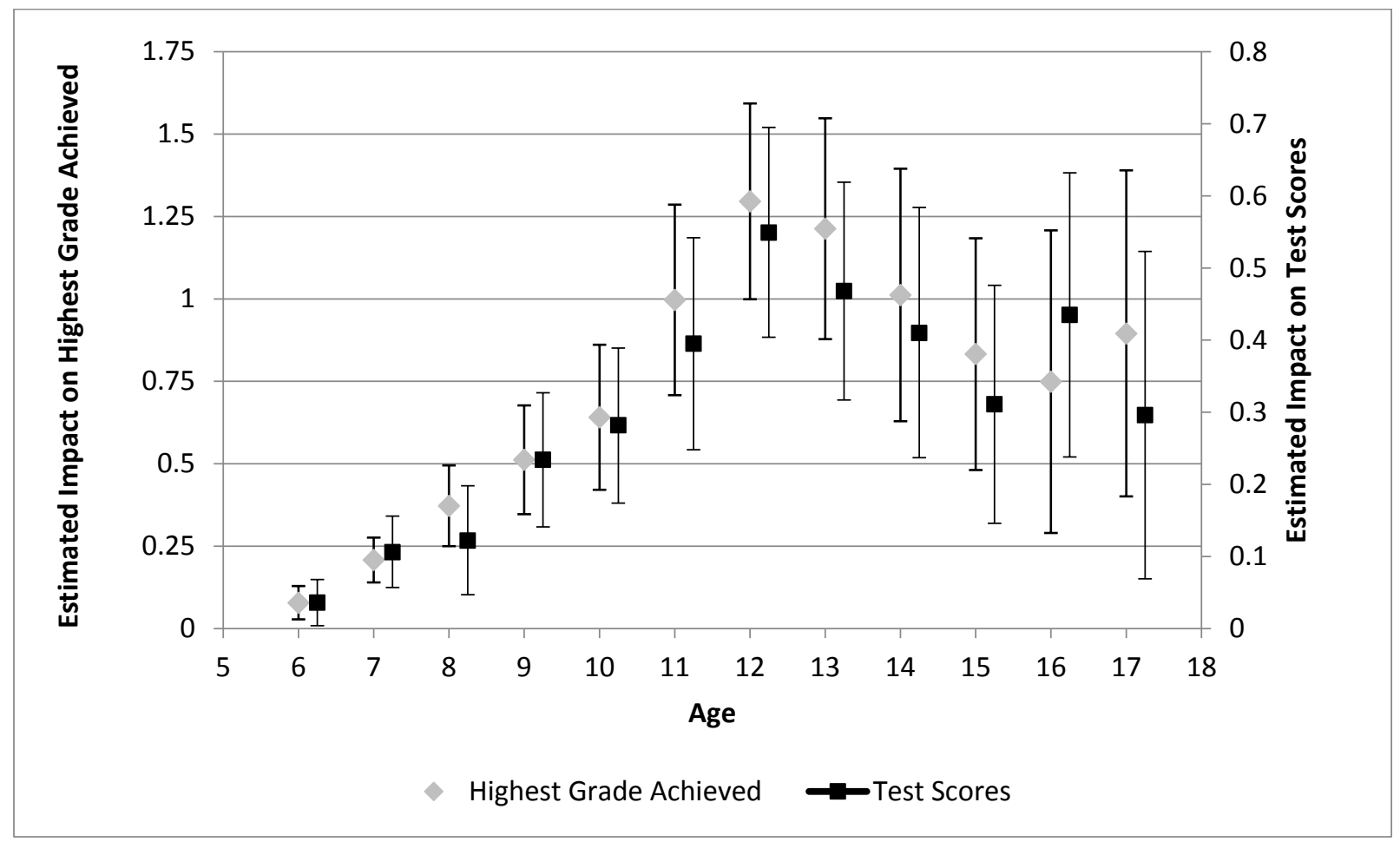

Note: The left vertical axis represents the estimated discontinuity for the highest grade achieved, with triangles indicating the point estimate and a line indicating the 95 percent confidence interval. The right vertical axis represents the estimated discontinuity for the total normalized test score point estimate, with squares indicating the point estimate and a line indicating the 95 percent confidence interval estimates. 
Table 1: Participation in BRIGHT II

\begin{tabular}{|c|c|c|c|c|c|c|}
\hline Dependent Variables & $(1)$ & (2) & (3) & (4) & (5) & (6) \\
\hline Selected for BRIGHT & $\begin{array}{c}0.885 * * * \\
(0.04)\end{array}$ & $\begin{array}{c}0.888 * * * \\
(0.04)\end{array}$ & $\begin{array}{c}0.884 * * * \\
(0.03)\end{array}$ & $\begin{array}{c}0.889 * * * \\
(0.03)\end{array}$ & $\begin{array}{c}0.902 * * * \\
(0.03)\end{array}$ & $\begin{array}{c}0.944 * * * \\
(0.13)\end{array}$ \\
\hline Relative Score & $\begin{array}{l}0.055 \\
(0.08)\end{array}$ & $\begin{array}{l}0.055 \\
(0.07)\end{array}$ & $\begin{array}{l}0.056 \\
(0.04)\end{array}$ & $\begin{array}{l}0.029 \\
(0.07)\end{array}$ & $\begin{array}{r}-0.372 \\
(0.24)\end{array}$ & $\begin{array}{c}0.939 * \\
(0.53)\end{array}$ \\
\hline Relative Score^2 & $\begin{array}{c}0 \\
(0.02)\end{array}$ & $\begin{array}{c}0 \\
(0.02)\end{array}$ & & $\begin{array}{l}0.095 \\
(0.07)\end{array}$ & $\begin{array}{l}-0.241 \\
(0.26)\end{array}$ & $\begin{array}{l}-0.197 \\
(0.13)\end{array}$ \\
\hline Relative Score^3 & & & & & $\begin{array}{c}0.615^{*} \\
(0.37)\end{array}$ & \\
\hline Relative Score x Selected & & & & & $\begin{array}{l}0.192 \\
(0.24)\end{array}$ & \\
\hline Relative Score ${ }^{\wedge} 2$ x Selected & & & & $\begin{array}{l}-0.024 \\
(0.02)\end{array}$ & & \\
\hline Constant & $\begin{array}{l}-0.066 \\
(0.07)\end{array}$ & $\begin{array}{l}-0.035 \\
(0.09)\end{array}$ & $\begin{array}{l}-0.065 \\
(0.06)\end{array}$ & $\begin{array}{l}-0.099 \\
(0.07)\end{array}$ & $\begin{array}{c}-0.180^{* *} \\
(0.08)\end{array}$ & \\
\hline Observations & 26,430 & 26,430 & 26,430 & 26,430 & 26,430 & 26,430 \\
\hline R-squared & 0.843 & 0.841 & 0.843 & 0.843 & 0.846 & \\
\hline Prob $>F$ & 0 & 0 & 0 & 0 & 0 & \\
\hline Chi-square test & & & & & & 0 \\
\hline Demographic controls & Yes & No & Yes & Yes & Yes & Yes \\
\hline Department fixed effects & Yes & Yes & Yes & Yes & Yes & Yes \\
\hline Model & Quadratic & Quadratic & Linear & Cubic & $\begin{array}{l}\text { Interacted } \\
\text { Quadratic }\end{array}$ & $\begin{array}{c}\text { Probit } \\
\text { quadratic }\end{array}$ \\
\hline
\end{tabular}

Note: Robsut standard errors in parentheses (clustered at the village level). ${ }^{* * *}$ Signficant at the 1 percent level, ** Significant at the 5 percent level, * Significant at the 10 percent level. This table presents estimates of the estimated discontinuity in the relationship between being selected for the BRIGHT program and receiving a BRIGHT school using the indicated specification for equation (1). Relative score is measured in units of 1,000 points because of the small magnitude of the coefficients. 
Table 2: Continuity Checks

\begin{tabular}{|c|c|c|c|c|c|c|c|}
\hline Variables & $\begin{array}{l}\text { Non-Selected } \\
\text { Limit } \\
(1)\end{array}$ & $\begin{array}{c}\text { Discontinuity } \\
\text { Estimate } \\
(2)\end{array}$ & $\begin{array}{c}\text { Sample } \\
\text { Size } \\
(3)\end{array}$ & & $\begin{array}{l}\text { Non-Selected } \\
\text { Limit } \\
(3) \\
\end{array}$ & $\begin{array}{c}\text { Discontinuity } \\
\text { Estimate } \\
(4)\end{array}$ & $\begin{array}{l}\text { Sample } \\
\text { Size } \\
(3) \\
\end{array}$ \\
\hline \multicolumn{4}{|l|}{ Child and Household Characteristics: } & \multicolumn{4}{|l|}{ Household Head Characteristics: } \\
\hline Child is Female & $\begin{array}{c}0.483 * * * \\
(0.01)\end{array}$ & $\begin{array}{c}0.015 * * \\
(0.01)\end{array}$ & 26,430 & Has Some Formal Education & $\begin{array}{c}0.123^{* * *} \\
(0.01)\end{array}$ & $\begin{array}{c}0.030 * * \\
(0.02)\end{array}$ & 26,322 \\
\hline \multirow[t]{2}{*}{ Child of Household Head } & $0.869 * * *$ & $(0.00)$ & 26,408 & Religion: & & & \\
\hline & $(0.01)$ & $(0.01)$ & & Muslim & $0.608 * * *$ & 0.00 & 26,371 \\
\hline \multirow[t]{2}{*}{ Child's Age } & $10.254 * * *$ & 0.08 & 26,430 & & $(0.03)$ & $(0.03)$ & \\
\hline & $(0.04)$ & $(0.05)$ & & Christian & $0.158 * * *$ & 0.03 & 26,371 \\
\hline \multirow[t]{2}{*}{ House Quality Index } & $(0.03)$ & $0.180 * * *$ & 25,261 & & $(0.02)$ & $(0.02)$ & \\
\hline & $(0.05)$ & $(0.06)$ & & Animist & $0.227 * * *$ & $(0.03)$ & 26,371 \\
\hline \multirow[t]{2}{*}{ Asset Index } & $0.159 * * *$ & 0.00 & 26,430 & & $(0.02)$ & $(0.02)$ & \\
\hline & $(0.04)$ & $(0.05)$ & & Ethnicity: & & & \\
\hline \multirow[t]{2}{*}{ Number of Household Members } & $9.316^{* * *}$ & $(0.27)$ & 26,430 & Mossi & $0.420 * * *$ & 0.04 & 25,599 \\
\hline & $(0.21)$ & $(0.22)$ & & & $(0.04)$ & $(0.03)$ & \\
\hline \multirow[t]{2}{*}{ Number of Children } & $5.576 * * *$ & $(0.15)$ & 26,430 & Peul & $0.171^{* * *}$ & 0.03 & 25,599 \\
\hline & $(0.13)$ & $(0.13)$ & & & $(0.03)$ & $(0.02)$ & \\
\hline \multirow[t]{4}{*}{ Year's Household in Village } & $36.802 * * *$ & $(0.80)$ & 26,305 & Gourmanche & $0.261 * * *$ & $(0.03)$ & 25,599 \\
\hline & $(0.83)$ & $(0.70)$ & & & $(0.04)$ & $(0.02)$ & \\
\hline & & & & Other & $0.100 * * *$ & $(0.01)$ & 25,599 \\
\hline & & & & & $(0.02)$ & $(0.02)$ & \\
\hline \multicolumn{8}{|c|}{$\begin{array}{l}\text { Note: Robsut standard errors in parentheses (clustered at the village level). }{ }^{* *} \text { Signficant at the } 1 \text { percent level, ** Significant at the } 5 \text { percent level, } \\
* \text { Significant at the } 10 \text { percent level. This table presents evidence of the continuity of the various child- and household-level characteristics with } \\
\text { respect to the relative score. For each characteristic, Columns } 1 \text { and } 3 \text { present the average characteristic for children and households in villages that } \\
\text { were not selected for the BRIGHT program calculated using no control variables and a quadratic specification for the relative score function. } \\
\text { Columns } 2 \text { and } 4 \text { present the estimated discontinuity in the given characteristic using equation (1) with no control variables and a quadratic } \\
\text { specification for the relative score function. }\end{array}$} \\
\hline
\end{tabular}


Table 3: Bright II and School Characteristics

\begin{tabular}{|c|c|c|c|c|c|c|c|}
\hline & $\begin{array}{l}\text { Non- } \\
\text { Selected } \\
\text { Limit } \\
(1) \\
\end{array}$ & $\begin{array}{c}\text { Discontinuity } \\
\text { Estimate } \\
(2) \\
\end{array}$ & $\begin{array}{c}\text { Sample } \\
\text { Size } \\
(3)\end{array}$ & & $\begin{array}{l}\text { Non- } \\
\text { Selected } \\
\text { Limit } \\
(3) \\
\end{array}$ & $\begin{array}{c}\text { Discontinuity } \\
\text { Estimate } \\
(4)\end{array}$ & $\begin{array}{c}\text { Sample } \\
\text { Size } \\
(3) \\
\end{array}$ \\
\hline Panel A: Accessibility & & & & Panel D: Teacher Characteristics & & & \\
\hline Village has a School & $\begin{array}{l}0.858 * * * \\
(0.03)\end{array}$ & $\begin{array}{c}0.099 * * \\
(0.05)\end{array}$ & 290 & Number of Teachers & $\begin{array}{l}3.335^{* * *} \\
(0.15)\end{array}$ & $\begin{array}{l}2.531^{* * *} \\
(0.25)\end{array}$ & 332 \\
\hline Direct Route Reported & $\begin{array}{c}0.858 * * * \\
(0.02)\end{array}$ & $\begin{array}{c}0.046^{*} \\
(0.03)\end{array}$ & 332 & Student-Teacher Ratio & $\begin{array}{l}45.920 * * * \\
\quad(1.95)\end{array}$ & $\begin{array}{l}-5.859 * * * \\
(2.23)\end{array}$ & 332 \\
\hline Estimated Travel Time & $\begin{array}{c}28.685^{* * *} \\
(1.86)\end{array}$ & $\begin{array}{c}-7.525^{* * *} \\
(2.28)\end{array}$ & 332 & Qualifications Index & $\begin{array}{l}(0.01) \\
(0.11)\end{array}$ & $\begin{array}{c}0.06 \\
(0.11)\end{array}$ & 330 \\
\hline Panel B: School Characteristics & & & & Panel E: Girl Friendly Resources & & & \\
\hline Years in Operation & $\begin{array}{c}8.202 * * * \\
(0.69)\end{array}$ & $\begin{array}{c}3.890 * * * \\
(1.25)\end{array}$ & 328 & Preschool & $\begin{array}{l}0.103 * * * \\
(0.03)\end{array}$ & $\begin{array}{l}0.572^{* * *} \\
(0.06)\end{array}$ & 332 \\
\hline Highest Grade Offered & $\begin{array}{c}4.962 * * * \\
(0.11)\end{array}$ & $\begin{array}{l}0.856 * * * \\
(0.14)\end{array}$ & 332 & $\begin{array}{l}\text { Dry-Rations for Only Girls (Note } \\
\text { from HH survey) }\end{array}$ & $\begin{array}{l}0.151^{* * * *} \\
(0.04)\end{array}$ & $\begin{array}{l}0.542^{* * *} \\
(0.06)\end{array}$ & 314 \\
\hline School is Oversubscribed & $\begin{array}{l}0.377 * * * \\
(0.04)\end{array}$ & $\begin{array}{l}-0.180 * * * \\
(0.06)\end{array}$ & 329 & Water Supply & $\begin{array}{l}0.488^{* * *} \\
\quad(0.04)\end{array}$ & $\begin{array}{c}0.424^{* * *} \\
\quad(0.06)\end{array}$ & 332 \\
\hline $\begin{array}{l}\text { Panel C: Other Resources } \\
\text { Usable Classrooms }\end{array}$ & $3.184^{* * *}$ & $2.297 * * *$ & 332 & Any Toilets & $\begin{array}{c}0.643^{* * *} \\
(0.04)\end{array}$ & $\begin{array}{c}0.334^{* * *} \\
(0.05)\end{array}$ & 332 \\
\hline Classroom Quality Index & $\begin{array}{c}(0.13) \\
-0.231^{* *}\end{array}$ & $\begin{array}{c}(0.20) \\
0.537 * * *\end{array}$ & 328 & Gender-Segregated Toilets & $\begin{array}{c}0.352 * * * \\
(0.04)\end{array}$ & $\begin{array}{c}0.541^{* * *} \\
(0.06)\end{array}$ & 332 \\
\hline Teacher Accommodations & $\begin{array}{c}(0.10) \\
1.693^{* * *}\end{array}$ & $\begin{array}{c}(0.14) \\
3.060 * * *\end{array}$ & 332 & Number of Female Teachers & $\begin{array}{c}1.023^{* * *} \\
(0.12)\end{array}$ & $\begin{array}{c}1.486^{* * *} \\
(0.21)\end{array}$ & 332 \\
\hline Students without desks & $\begin{array}{c}(0.17) \\
0.261^{* * *} \\
(0.03)\end{array}$ & $\begin{array}{c}(0.34) \\
-0.168 * * * \\
(0.04)\end{array}$ & 329 & $\begin{array}{l}\text { leacners with Gender sensitivity } \\
\text { Training }\end{array}$ & $\begin{array}{l}0.194^{* * *} \\
\quad(0.03)\end{array}$ & $\begin{array}{l}0.156^{* * *} \\
(0.05)\end{array}$ & 331 \\
\hline
\end{tabular}


All students have own reading book

$\begin{array}{ccc}0.602 * * * & (0.07) & 330 \\ (0.05) & (0.05) & \\ & & \\ 0.540 * * * & (0.01) & 329 \\ (0.05) & (0.06) & \\ 0.810^{* * *} & 0.02 & 332 \\ (0.04) & (0.06) & \\ & & \\ 0.195^{* * *} & 0.454^{* * *} & 332 \\ (0.04) & (0.06) & \end{array}$

(All programs, including girls only)

(0.04)

Note: Robsut standard errors in parentheses (clustered at the village level). ${ }^{* * *}$ Significant at the 1 percent level, ** Significant at the 5 percent level, * Significant at the 10 percent level. This table presents estimates of the school characteristics for schools based on whether or not the village served by the school was selected for the BRIGHT program. Columns 1 and 3 present the average characteristics for schools in villages that were not selected for the program calculated using no control variables and a quadratic specification for the relative score function. Columns 2 and 4 present the estimated discontinuity in the given characteristic using equation (1) with no control variables and a quadratic specification for the relative score function. 


\begin{tabular}{|c|c|c|c|c|c|c|c|c|}
\hline Dependent Variables & $\begin{array}{l}\text { (1) } \\
\text { Reported } \\
\text { enroll- } \\
\text { ment }\end{array}$ & $\begin{array}{l}\text { (2) } \\
\text { Reported } \\
\text { enroll- } \\
\text { ment }\end{array}$ & $\begin{array}{l}\text { (3) } \\
\text { Reported } \\
\text { enroll- } \\
\text { ment }\end{array}$ & $\begin{array}{c}\text { (4) } \\
\text { Reported } \\
\text { enroll- } \\
\text { ment }\end{array}$ & $\begin{array}{l}\text { (5) } \\
\text { Reported } \\
\text { enroll- } \\
\text { ment }\end{array}$ & $\begin{array}{c}\text { (6) } \\
\text { Reported } \\
\text { enroll- } \\
\text { ment }\end{array}$ & $\begin{array}{c}\text { (7) } \\
\text { Verified } \\
\text { enroll- } \\
\text { ment }\end{array}$ & $\begin{array}{l}\text { (8) } \\
\text { Highest } \\
\text { Grade }\end{array}$ \\
\hline $\begin{array}{l}\text { Selected for } \\
\text { BRIGHT }\end{array}$ & $\begin{array}{c}0.155^{* * *} \\
(0.02)\end{array}$ & $\begin{array}{c}0.166 * * * \\
(0.02)\end{array}$ & $\begin{array}{c}0.160 * * * \\
(0.02)\end{array}$ & $\begin{array}{c}0.158 * * * \\
(0.02)\end{array}$ & $\begin{array}{c}0.167 * * * \\
(0.02)\end{array}$ & $\begin{array}{c}0.172 * * * \\
(0.02)\end{array}$ & $\begin{array}{c}0.100 * * * \\
(0.02)\end{array}$ & $\begin{array}{c}0.673 * * * \\
(0.07)\end{array}$ \\
\hline Relative Score & $\begin{array}{l}0.035 \\
(0.03)\end{array}$ & $\begin{array}{l}0.055 \\
(0.04)\end{array}$ & $\begin{array}{l}0.016 \\
(0.02)\end{array}$ & $\begin{array}{l}0.022 \\
(0.03)\end{array}$ & $\begin{array}{c}-0.176 \\
(0.18)\end{array}$ & $\begin{array}{l}0.027 \\
(0.04)\end{array}$ & $\begin{array}{c}0.068 * \\
(0.04)\end{array}$ & $\begin{array}{c}0.242 * \\
(0.15)\end{array}$ \\
\hline Relative Score^2 & $\begin{array}{l}-0.008 \\
(0.01)\end{array}$ & $\begin{array}{l}-0.013 \\
(0.01)\end{array}$ & & $\begin{array}{l}0.039 \\
(0.04)\end{array}$ & $\begin{array}{l}-0.251 \\
(0.23)\end{array}$ & $\begin{array}{l}-0.005 \\
(0.01)\end{array}$ & $\begin{array}{l}-0.015 \\
(0.01)\end{array}$ & $\begin{array}{l}-0.063 \\
(0.04)\end{array}$ \\
\hline Relative Score^3 & & & & & $\begin{array}{l}0.252 \\
(0.21)\end{array}$ & & & \\
\hline $\begin{array}{l}\text { Relative Score x } \\
\text { Selected }\end{array}$ & & & & & $\begin{array}{l}0.233 \\
(0.23)\end{array}$ & & & \\
\hline Relative Score $\wedge 2 \times \mathrm{Se}$ & ected & & & $\begin{array}{l}-0.012 \\
(0.01)\end{array}$ & & & & \\
\hline Constant & $\begin{array}{c}0.333 * * * \\
(0.05)\end{array}$ & $\begin{array}{c}0.512 * * * \\
(0.03)\end{array}$ & $\begin{array}{c}0.331 * * * \\
(0.05)\end{array}$ & $\begin{array}{c}0.317 * * * \\
(0.05)\end{array}$ & $\begin{array}{c}0.301^{* * * *} \\
(0.06)\end{array}$ & & $\begin{array}{c}0.295^{* * *} \\
(0.06)\end{array}$ & $\begin{array}{c}0.931^{* * * *} \\
(0.19)\end{array}$ \\
\hline Observations & 26,430 & 26,430 & 26,430 & 26,430 & 26,430 & 26,430 & 26,430 & 26,430 \\
\hline R-squared & 0.129 & 0.098 & 0.129 & 0.129 & 0.13 & & 0.097 & 0.206 \\
\hline Prob $>F$ & 0.000 & 0.000 & 0.000 & 0.000 & 0.000 & 0.000 & 0.000 & 0 \\
\hline $\begin{array}{l}\text { Chi-square test } \\
\text { Demographic } \\
\text { controls } \\
\text { Department fixed }\end{array}$ & Yes & No & Yes & Yes & Yes & 0.000 & Yes & Yes \\
\hline effects & Yes & Yes & Yes & Yes & Yes & Yes & Yes & Yes \\
\hline Non-Selected Limit & $\begin{array}{c}0.321 * * * \\
(0.02)\end{array}$ & $\begin{array}{c}0.321^{* * * *} \\
(0.02)\end{array}$ & $\begin{array}{c}0.315 * * * \\
(0.02)\end{array}$ & $\begin{array}{c}0.313^{* * *} \\
(0.02)\end{array}$ & $\begin{array}{c}0.311^{* * *} \\
(0.02)\end{array}$ & & $\begin{array}{c}0.278 * * * \\
(0.02)\end{array}$ & $\begin{array}{c}1.112^{* * *} \\
(0.06)\end{array}$ \\
\hline Model & Quadratic & Quadratic & Linear & Cubic & $\begin{array}{l}\text { Interacted } \\
\text { Quadratic }\end{array}$ & $\begin{array}{c}\text { Probit } \\
\text { quadratic }\end{array}$ & Quadratic & Quadratic \\
\hline \multicolumn{9}{|c|}{$\begin{array}{l}\text { Note: Robsut standard errors in parentheses (clustered at the village level). *** Signficant at the } 1 \text { percent level, ** } \\
\text { Significant at the } 5 \text { percent level, * Significant at the } 10 \text { percent level. This table presents estimates of the estimated } \\
\text { discontinuity in the relationship between a child's probability of being enrolled during the 2012-2013 academic year and } \\
\text { the child's village being selected for the BRIGHT program using the indicated specification for equation (1). Columns } 1-6 \\
\text { show estimates of the model based on self-reported enrollment information. Column } 7 \text { uses a model based on whether or } \\
\text { not a child was directly observed in class during the survey of the child's school. Column } 8 \text { uses a model based on the } \\
\text { highest grade a child achieved in school, regardless of current enrollment. Relative score is measured in units of } 1,000 \\
\text { points because of the small magnitude of the coefficients. }\end{array}$} \\
\hline
\end{tabular}


Table 5: Total Test Scores

\begin{tabular}{|c|c|c|c|c|c|}
\hline & $(1)$ & $(2)$ & (3) & $(4)$ & $(5)$ \\
\hline Selected for BRIGHT & $\begin{array}{c}0.290 * * * \\
(0.03)\end{array}$ & $\begin{array}{c}0.316^{* * *} \\
(0.04)\end{array}$ & $\begin{array}{c}0.293^{* * *} \\
(0.03)\end{array}$ & $\begin{array}{c}0.299 * * * \\
(0.04)\end{array}$ & $\begin{array}{c}0.343^{* * *} \\
(0.04)\end{array}$ \\
\hline Relative Score & $\begin{array}{l}0.036 \\
(0.08)\end{array}$ & $\begin{array}{l}0.078 \\
(0.09)\end{array}$ & $\begin{array}{r}0.023 \\
(0.04)\end{array}$ & $\begin{array}{l}-0.018 \\
(0.10)\end{array}$ & $\begin{array}{c}-0.907 * * \\
(0.36)\end{array}$ \\
\hline Relative Score^2 & $\begin{array}{l}-0.005 \\
(0.02)\end{array}$ & $\begin{array}{l}-0.016 \\
(0.02)\end{array}$ & & $\begin{array}{l}0.155 \\
(0.12)\end{array}$ & $\begin{array}{c}-1.310^{* * *} \\
(0.44)\end{array}$ \\
\hline Relative Score $\wedge 3$ & & & & & $\begin{array}{c}1.049 * * \\
(0.41)\end{array}$ \\
\hline Relative Score x Selected & & & & & $\begin{array}{c}1.281 * * * \\
(0.44)\end{array}$ \\
\hline Relative Score $\wedge 2$ x Selected & & & & $\begin{array}{c}-0.039 \\
(0.03)\end{array}$ & \\
\hline Constant & $\begin{array}{c}-1.353 * * * \\
(0.11)\end{array}$ & $\begin{array}{l}0.088 \\
(0.09)\end{array}$ & $\begin{array}{c}-1.355^{* * *} \\
(0.11)\end{array}$ & $\begin{array}{c}-1.410 * * * \\
(0.12)\end{array}$ & $\begin{array}{c}-1.458 * * * \\
(0.13)\end{array}$ \\
\hline Observations & 23,464 & 23,464 & 23,464 & 23,464 & 23,464 \\
\hline R-squared & 0.259 & 0.101 & 0.259 & 0.259 & 0.26 \\
\hline Prob $>F$ & 0.000 & 0.000 & 0.000 & 0.000 & 0.000 \\
\hline Demographic controls & Yes & No & Yes & Yes & Yes \\
\hline Department fixed effects & Yes & Yes & Yes & Yes & Yes \\
\hline Non-Selected Limit & $\begin{array}{c}-0.155 * * * \\
(0.03)\end{array}$ & $\begin{array}{c}-0.155^{* * *} \\
(0.03)\end{array}$ & $\begin{array}{c}-0.164 * * * \\
(0.03)\end{array}$ & $\begin{array}{c}-0.172 * * * \\
(0.03)\end{array}$ & $\begin{array}{c}-0.227 * * * \\
(0.04)\end{array}$ \\
\hline Model & Quadratic & Quadratic & Linear & Cubic & $\begin{array}{l}\text { Interacted } \\
\text { Quadratic }\end{array}$ \\
\hline
\end{tabular}

Note: Robsut standard errors in parentheses (clustered at the village level). ${ }^{* * *}$ Signficant at the 1 percent level, ** Significant at the 5 percent level, * Significant at the 10 percent level. This table presents estimates of the estimated discontinuity in the relationship between normalized total test scores and the child's village being selected for the BRIGHT program. Columns 1-5 show estimates of the model using the indicated specification for equation (1). Relative score is measured in units of 1,000 points because of the small magnitude of the coefficients. 
Table 6: Explanations for Test Score Effects

\begin{tabular}{|c|c|c|c|c|c|c|}
\hline & \multicolumn{2}{|c|}{ Highest Grade } & \multicolumn{2}{|c|}{ Years Had School } & \multicolumn{2}{|c|}{ Number of Grades } \\
\hline & $(1)$ & $(2)$ & (3) & (4) & $(5)$ & $(6)$ \\
\hline \multirow[t]{2}{*}{ Selected for BRIGHT } & 0.010 & 0.008 & $0.231^{* * *}$ & $0.288 * * *$ & $0.232 * * *$ & $0.233 * * *$ \\
\hline & $(0.018)$ & $(0.018)$ & $(0.039)$ & $(0.034)$ & (0.039) & $(0.037)$ \\
\hline \multirow[t]{2}{*}{ Relative Score } & $-0.080 *$ & $-0.083 *$ & 0.025 & 0.037 & 0.051 & 0.049 \\
\hline & $(0.043)$ & $(0.044)$ & $(0.092)$ & $(0.080)$ & $(0.078)$ & $(0.079)$ \\
\hline \multirow[t]{2}{*}{ Relative Score^2 } & $0.028 * *$ & $0.028 * *$ & -0.006 & -0.005 & -0.01 & -0.008 \\
\hline & $(0.012)$ & $(0.012)$ & $(0.023)$ & $(0.021)$ & $(0.020)$ & $(0.021)$ \\
\hline \multirow[t]{3}{*}{ Linear control variable } & & $0.395 * * *$ & & 0.000 & & $0.049 * * *$ \\
\hline & & $(0.005)$ & & $(0.002)$ & & $(0.010)$ \\
\hline & - & - & - & - & - & \\
\hline \multirow[t]{2}{*}{ Constant } & $0.943 * * *$ & $0.991 * * *$ & $1.518 * * *$ & $1.365^{* * *}$ & $1.583 * * *$ & $-1.598 * * *$ \\
\hline & $(0.070)$ & $(0.069)$ & $(0.144)$ & $(0.122)$ & $(0.122)$ & $(0.122)$ \\
\hline Observations & 23,194 & 23,194 & 23,461 & 23,461 & 23,461 & 23,461 \\
\hline R-squared & 0.797 & 0.796 & 0.273 & 0.259 & 0.263 & 0.263 \\
\hline Prob $>F$ & 0.000 & 0.000 & 0.000 & 0.000 & 0.000 & 0.000 \\
\hline Demographic controls & Yes & Yes & Yes & Yes & Yes & Yes \\
\hline Department fixed effects & Yes & Yes & Yes & Yes & Yes & Yes \\
\hline Model & FE & Linear & FE & Linear & $\mathrm{FE}$ & Linear \\
\hline
\end{tabular}

Note: Robsut standard errors in parentheses (clustered at the village level). ${ }^{* * *}$ Signficant at the 1 percent level, ** Significant at the 5 percent level, * Significant at the 10 percent level. This table presents estimates of the estimated discontinuity in the relationship between total normalized test score and the child's village being selected for the BRIGHT program. Columns 1, 3, and 5 show estimates of the model using the indicated specification for equation (1) and including fixed effects for the indicated variable. Columns 2, 4, and 6 show estimates of the model using the indicated specification for equation (1) and including the indicated variable as a control in the regression. Relative score is measured in units of 1,000 points because of the small magnitude of the coefficients. 


\begin{tabular}{|c|c|c|c|}
\hline $\begin{array}{l}\text { Non-Selected } \\
\text { Limit }\end{array}$ & \multicolumn{2}{|c|}{$\begin{array}{c}\text { Discontinuity } \\
\text { Estimate } \\
\end{array}$} & $\begin{array}{c}\text { Sample } \\
\text { Size }\end{array}$ \\
\hline & \multicolumn{2}{|c|}{ Controls } & \\
\hline (1) & $\begin{array}{l}\text { No } \\
(2)\end{array}$ & $\begin{array}{l}\text { Yes } \\
(3)\end{array}$ & (4) \\
\hline
\end{tabular}

\section{Panel A: Age Relative to Grade}

On age for grade

Student is too old for grade

Student is too young for grade

Year's off grade level

\section{Panel B: Grade Promotion} Irregularities

Start School Between 5 and 7

Years older than 7 at start

Skipped Ever

Years Skipped

Repeated Ever

Years Repeated

Break in School (Always one year)

Ever Changed Schools

\section{$0.357 * * *$ \\ $-0.012$}

$0.642 * * *$

$-0.012$

0.001

$-0.001$

$1.262 * * *$

$-0.038$

$0.654 * * *$

$-0.015$

$0.291 * * *$

$-0.022$

$0.014 * * *$

$-0.003$

$0.009 * * *$

$-0.002$

$0.185^{* * *}$

$-0.014$

$0.219 * * *$

$-0.018$

$0.014 * * *$

$-0.002$

$0.029 * * *$

$-0.004$

$$
\begin{array}{cc}
0.082 * * * & 0.089 * * * \\
-0.019 & -0.013 \\
- & -
\end{array}
$$

$0.085 * * *$

$0.093^{* * *}$

$-0.013$

$-0.019$

$0.003 * *$

$0.004 * * *$

$-0.001 \quad-0.001$

11,507

$\begin{array}{cc}- & - \\ 0.222^{* * *} & 0.272^{* * *}\end{array}$

$-0.056 \quad-0.044$

10,523

11,507$$
-0.056
$$

0.044

$$
\begin{array}{cc}
0.086^{* * *} & 0.095^{* * *} \\
-0.022 & -0.017 \\
- & -
\end{array}
$$

$\begin{array}{ccc}0.112 * * * & 0.120 * * * & 11,507 \\ -0.03 & -0.025 & \\ 0.001 & 0.003 & 10,878 \\ -0.004 & -0.004 & \end{array}$

$0.001 \quad 0.002$

10,828

$-0.004 \quad-0.004$

$0.013 \quad 0.033^{* * *}$

10,873

$-0.021 \quad-0.012$

$0.007 \quad 0.033^{* *}$

10,787

$-0.027 \quad-0.015$

$\begin{array}{ll}-0.002 & 0.000\end{array}$

10,840

$-0.004 \quad-0.003$

$-0.006 \quad-0.009$

10,867

$-0.006 \quad-0.006$

Note: Robsut standard errors in parentheses (clustered at the village level). ${ }^{* * *}$ Signficant at the 1 percent level, ** Significant at the 5 percent level, * Significant at the 10 percent level. This table presents estimates of the characteristics of student enrollment patterns based on whether or not the child's village was selected for the BRIGHT program. Column 1 presents the average characteristics for students in villages that were not selected for the program calculated using no control variables and a quadratic specification for the relative score function. Column 2 presents the estimated discontinuity in the given characteristic using equation (1) with no control variables, and Column 3 is the estimated discontinuity using equation (1) with control variables included. 
Table 8: BRIGHT II Impacts on Child Anthropometric Outcomes

\begin{tabular}{|c|c|c|c|c|c|c|c|}
\hline & $\begin{array}{c}\text { Non-Selected } \\
\text { Limit } \\
(1) \\
\end{array}$ & $\begin{array}{c}\text { Discontinuity } \\
\text { Estimate } \\
(2) \\
\end{array}$ & $\begin{array}{l}\text { Sample } \\
\text { Size } \\
(3) \\
\end{array}$ & & $\begin{array}{c}\text { Non-Selected } \\
\text { Limit } \\
(3) \\
\end{array}$ & $\begin{array}{c}\text { Discontinuity } \\
\text { Estimate } \\
(4) \\
\end{array}$ & $\begin{array}{c}\text { Sample } \\
\text { Size } \\
(3) \\
\end{array}$ \\
\hline Panel A: Child Health Outcomes & & & & \multicolumn{4}{|c|}{ Panel C: Household Consumption } \\
\hline Arm circumference & $\begin{array}{c}161.873^{* * *} \\
(4.82)\end{array}$ & $\begin{array}{c}1.10 \\
(1.10)\end{array}$ & 26,074 & Sorghum & $\begin{array}{c}0.852^{* * *} \\
(0.02)\end{array}$ & $\begin{array}{c}0.02 \\
(0.02)\end{array}$ & 26,452 \\
\hline Height for Age & $\begin{array}{c}-0.952 * * * \\
(0.04)\end{array}$ & $\begin{array}{l}(0.05) \\
(0.06)\end{array}$ & 26,024 & Millet & $\begin{array}{c}0.702 * * * \\
(0.02)\end{array}$ & $\begin{array}{c}0.00 \\
(0.02)\end{array}$ & 26,266 \\
\hline Weight for Age & $\begin{array}{c}-0.963^{* * *} \\
(0.05)\end{array}$ & $\begin{array}{l}(0.08) \\
(0.06)\end{array}$ & 14,597 & Homemade Beer & $\begin{array}{c}0.193 * * * \\
(0.02)\end{array}$ & $\begin{array}{c}0.02 \\
(0.02)\end{array}$ & 25,788 \\
\hline Weight for Height & $\begin{array}{c}-0.252^{* *} \\
(0.11)\end{array}$ & $\begin{array}{c}0.00 \\
(0.11)\end{array}$ & 7,114 & Rice & $\begin{array}{c}0.526 * * * \\
(0.02)\end{array}$ & $\begin{array}{c}0.038 * \\
(0.02)\end{array}$ & 26,215 \\
\hline BMI & $\begin{array}{c}16.150 * * * \\
(0.10)\end{array}$ & $\begin{array}{c}0.02 \\
(0.13)\end{array}$ & 25,982 & Bread & $\begin{array}{c}0.191^{* * *} \\
(0.01)\end{array}$ & $\begin{array}{c}0.042 * * \\
(0.02)\end{array}$ & 26,164 \\
\hline $\begin{array}{c}\text { Panel B: Program Participation } \\
\text { Participate in Feeding Program }\end{array}$ & $0.235^{* * *}$ & $0.172 * * *$ & 25,950 & Pasta & $\begin{array}{c}0.155^{* * *} \\
(0.01)\end{array}$ & $\begin{array}{c}0.02 \\
(0.02)\end{array}$ & 25,951 \\
\hline Participate in Feeding Program & $(0.02)$ & $\begin{array}{l}0.1 / 2 \text { (0.02) } \\
(0.02)\end{array}$ & 25,950 & Meat & $0.612^{* * *}$ & $(0.00)$ & 26,227 \\
\hline Days per week in program & $\begin{array}{c}1.036 * * * \\
(0.09)\end{array}$ & $\begin{array}{c}0.805^{* * *} \\
(0.10)\end{array}$ & 25,761 & Fish & $\begin{array}{c}(0.02) \\
0.638 * * *\end{array}$ & $\begin{array}{c}(0.02) \\
0.01\end{array}$ & 26,174 \\
\hline Attends school with dry Rations & $\begin{array}{c}0.068^{* * *} \\
(0.01)\end{array}$ & $\begin{array}{c}0.302 * * * \\
(0.02)\end{array}$ & 25,922 & Consumption Index & $\begin{array}{c}(0.03) \\
3.863^{* * *}\end{array}$ & $\begin{array}{c}(0.02) \\
0.13\end{array}$ & 26,430 \\
\hline Attends school with girl only dry rations & $\begin{array}{c}0.065^{* * *} \\
(0.01)\end{array}$ & $\begin{array}{c}0.289 * * * \\
(0.02)\end{array}$ & 25,772 & & $(0.07)$ & $(0.08)$ & \\
\hline
\end{tabular}

Note: Robsut standard errors in parentheses (clustered at the village level). *** Signficant at the 1 percent level, ** Significant at the 5 percent level, * Significant at the 10 percent level. This table presents estimates of child health characteristics, program participation characteristics, and household consumption characteristics based on whether or not the child's village was selected for the BRIGHT program. Columns 1 and 3 present the average characteristics of children in villages that were not selected for the program calculated using no control variables and a quadratic specification for the relative score function. Columns 2 and 4 present the estimated discontinuity in the given characteristic using equation (1) with control variables included. 


\section{Table 9: Child Labor}

\begin{tabular}{|c|c|c|c|c|c|c|c|}
\hline Dependent Variables & $\begin{array}{c}\text { Firewood } \\
(1) \\
\end{array}$ & $\begin{array}{c}\text { Cleaning } \\
(2) \\
\end{array}$ & $\begin{array}{c}\text { Fetch } \\
\text { Water } \\
(3) \\
\end{array}$ & $\begin{array}{c}\text { Watch } \\
\text { Siblings } \\
(4)\end{array}$ & $\begin{array}{c}\text { Tend } \\
\text { Animals } \\
(5)\end{array}$ & $\begin{array}{c}\text { Shopping } \\
(6) \\
\end{array}$ & $\begin{array}{c}\text { Overall } \\
\text { Index } \\
(7) \\
\end{array}$ \\
\hline Selected for BRIGHT & $\begin{array}{c}-0.061^{* * *} \\
(0.015)\end{array}$ & $\begin{array}{c}-0.038 * * * \\
(0.012)\end{array}$ & $\begin{array}{c}-0.039 * * * \\
(0.013)\end{array}$ & $\begin{array}{c}-0.028 * * \\
(0.014)\end{array}$ & $\begin{array}{c}-0.053^{* * *} \\
(0.014)\end{array}$ & $\begin{array}{c}-0.022 * \\
(0.012)\end{array}$ & $\begin{array}{c}-0.139 * * * \\
(0.029)\end{array}$ \\
\hline Relative Score & $\begin{array}{c}0.052 * \\
(0.029)\end{array}$ & $\begin{array}{c}0.023 \\
(0.031)\end{array}$ & $\begin{array}{c}0.014 \\
(0.035)\end{array}$ & $\begin{array}{c}0.01 \\
(0.033)\end{array}$ & $\begin{array}{c}-0.013 \\
(0.033)\end{array}$ & $\begin{array}{c}0.019 \\
(0.025)\end{array}$ & $\begin{array}{c}0.058 \\
(0.076)\end{array}$ \\
\hline Relative Score^2 & $\begin{array}{c}0.004 \\
(0.008)\end{array}$ & $\begin{array}{c}0.003 \\
(0.008)\end{array}$ & $\begin{array}{c}0.002 \\
(0.009)\end{array}$ & $\begin{array}{c}0.001 \\
(0.009)\end{array}$ & $\begin{array}{l}0.016^{*} \\
(0.009)\end{array}$ & $\begin{array}{c}0.001 \\
(0.006)\end{array}$ & $\begin{array}{c}0.018 \\
(0.021)\end{array}$ \\
\hline Constant & $\begin{array}{l}-0.068 \\
(0.071)\end{array}$ & $\begin{array}{c}0.182 * * * \\
(0.063)\end{array}$ & $\begin{array}{c}0.167 * * \\
(0.072)\end{array}$ & $\begin{array}{c}0.542 * * * \\
(0.080)\end{array}$ & $\begin{array}{c}0.169 * * * \\
(0.050)\end{array}$ & $\begin{array}{c}0.439 * * * \\
(0.085)\end{array}$ & $\begin{array}{c}-0.664 * * * \\
(0.163)\end{array}$ \\
\hline Observations & 25,302 & 25,179 & 25,289 & 25,220 & 25,081 & 25,217 & 26,430 \\
\hline R-squared & 0.156 & 0.204 & 0.177 & 0.127 & 0.156 & 0.193 & 0.159 \\
\hline Prob $>F$ & 0.000 & 0.000 & 0.000 & 0.000 & 0.000 & 0.000 & 0.000 \\
\hline Demographic controls & Yes & Yes & Yes & Yes & Yes & Yes & Yes \\
\hline Department fixed effects & Yes & Yes & Yes & Yes & Yes & Yes & Yes \\
\hline Non-Selected Limit & $\begin{array}{c}0.440 * * * \\
(0.015)\end{array}$ & $\begin{array}{c}0.480 * * * \\
(0.012)\end{array}$ & $\begin{array}{c}0.725^{* * * *} \\
(0.013)\end{array}$ & $\begin{array}{c}0.521 * * * \\
(0.015)\end{array}$ & $\begin{array}{c}0.367 * * * \\
(0.015)\end{array}$ & $\begin{array}{c}0.298 * * * \\
(0.019)\end{array}$ & $\begin{array}{l}0.050 * \\
(0.029)\end{array}$ \\
\hline Model & Quadratic & Quadratic & Quadratic & Quadratic & Quadratic & Quadratic & Quadratic \\
\hline
\end{tabular}

Note: Robust standard errors in parentheses (clustered at the village level). *** Signficant at the 1 percent level, ** Significant at the 5 percent level, * Significant at the 10 percent level. This table presents estimates of the estimated discontinuity in the relationship between the probability that a child engages in the indicated activitiy and the child's village being selected for the BRIGHT program using the indicated specification for equation (1). Only activities in which at least 10 percent of children participated are shown and included in Column 10. Relative score is measured in units of 1,000 points because of the small magnitude of the coefficients. 
Table 10: Heterogeneity by Gender

(1)

(2)

(3)

(4)

(5)

(6)

(7)

\section{Panel A: Academic Outcomes}

\begin{tabular}{lcccc} 
Dependent Variable & $\begin{array}{c}\text { Self-Reported } \\
\text { Enrollment }\end{array}$ & $\begin{array}{c}\text { Verified } \\
\text { Enrollment }\end{array}$ & $\begin{array}{c}\text { Total } \\
\text { Score }\end{array}$ & $\begin{array}{c}\text { Highest } \\
\text { Grade }\end{array}$ \\
\hline Selected for BRIGHT & $0.100^{* * *}$ & $0.047^{* *}$ & $0.188^{* * *}$ & $0.456^{* * *}$ \\
& $(0.017)$ & $(0.019)$ & $(0.035)$ & $(0.069)$ \\
Selected for BRIGHT * Female & $0.113^{* * *}$ & $0.107^{* * *}$ & $0.205^{* * *}$ & $0.468^{* * *}$ \\
& $(0.015)$ & $(0.015)$ & $(0.030)$ & $(0.062)$ \\
Female & & & - & \\
& -0.014 & -0.013 & $0.068^{* * *}$ & $-0.094^{* *}$ \\
Observations & $(0.009)$ & $(0.009)$ & $(0.018)$ & $(0.037)$ \\
R-squared & 26,430 & 26,430 & 23,464 & 26,080 \\
Prob>F & 0.132 & 0.1 & 0.262 & 0.216 \\
& 0.000 & 0.000 & 0.000 & 0.000
\end{tabular}

\section{Panel B: Growth}

Dependent Variable

Arm

Weight

for

\begin{tabular}{lccccc} 
& Circumference & Height & Weight & Height & BMI \\
\hline Selected for BRIGHT & 1.185 & -0.016 & -0.059 & -0.049 & -0.017 \\
& $(1.15)$ & $(0.06)$ & $(0.06)$ & $(0.13)$ & $(0.13)$ \\
Selected for BRIGHT * Female & -0.177 & $-0.075^{*}$ & -0.047 & 0.097 & 0.08 \\
& $(0.84)$ & $(0.05)$ & $(0.06)$ & $(0.11)$ & $(0.12)$ \\
& & & & - & \\
Female & $4.446^{* * *}$ & $0.143^{* * *}$ & -0.057 & $0.489 * * *$ & $-0.162^{*}$ \\
& $(0.54)$ & $(0.03)$ & $(0.04)$ & $(0.08)$ & $(0.08)$ \\
Observations & 26,074 & 26,024 & 14,597 & 7,111 & 25,982 \\
R-squared & 0.779 & 0.074 & 0.067 & 0.168 & 0.094 \\
Prob>F & 0.000 & 0.000 & 0.000 & 0.000 & 0.000
\end{tabular}




\begin{tabular}{|c|c|c|c|c|c|c|c|}
\hline $\begin{array}{c}\text { Panel C: Child Labor } \\
\text { Dependent Variable }\end{array}$ & Firewood & Cleaning & $\begin{array}{l}\text { Fetch } \\
\text { Water }\end{array}$ & $\begin{array}{l}\text { Watch } \\
\text { Siblings }\end{array}$ & $\begin{array}{c}\text { Tend } \\
\text { Animals }\end{array}$ & Shopping & $\begin{array}{c}\text { Overall } \\
\text { Index }\end{array}$ \\
\hline Selected for BRIGHT & $\begin{array}{l}-0.028 * \\
(0.016)\end{array}$ & $\begin{array}{l}-0.019 \\
(0.016)\end{array}$ & $\begin{array}{c}-0.037 * * \\
(0.017)\end{array}$ & $\begin{array}{l}-0.025 \\
(0.016)\end{array}$ & $\begin{array}{c}- \\
0.053^{* * *} \\
(0.017)\end{array}$ & $\begin{array}{l}-0.021 \\
(0.013)\end{array}$ & $\begin{array}{c}- \\
0.113^{* * *} \\
(0.032)\end{array}$ \\
\hline Selected for BRIGHT * Female & $\begin{array}{c}-0.067 * * * \\
(0.016)\end{array}$ & $\begin{array}{c}-0.038 * * \\
(0.019)\end{array}$ & $\begin{array}{l}-0.005 \\
(0.019)\end{array}$ & $\begin{array}{l}-0.005 \\
(0.017)\end{array}$ & $\begin{array}{c}0.001 \\
(0.017)\end{array}$ & $\begin{array}{l}-0.004 \\
(0.011)\end{array}$ & $\begin{array}{l}-0.054^{*} \\
(0.030)\end{array}$ \\
\hline Female & $\begin{array}{c}0.207 * * * \\
(0.012)\end{array}$ & $\begin{array}{c}0.364 * * * \\
(0.014)\end{array}$ & $\begin{array}{c}0.164 * * * \\
(0.013)\end{array}$ & $\begin{array}{c}0.206 * * * \\
(0.012)\end{array}$ & $\begin{array}{c}- \\
0.229 * * * \\
(0.012)\end{array}$ & $\begin{array}{c}0.022 * * * \\
(0.008)\end{array}$ & $\begin{array}{c}0.403^{* * *} \\
(0.021)\end{array}$ \\
\hline Observations & 25,302 & 25,179 & 25,289 & 25,220 & 25,081 & 25,217 & 26,430 \\
\hline R-squared & 0.157 & 0.204 & 0.177 & 0.127 & 0.156 & 0.193 & 0.159 \\
\hline Prob $>F$ & 0.000 & 0.000 & 0.000 & 0.000 & 0.000 & 0.000 & 0.000 \\
\hline
\end{tabular}

Note: Robsut standard errors in parentheses (clustered at the village level). ${ }^{* * *}$ Signficant at the 1 percent level, ** Significant at the 5 percent level, * Significant at the 10 percent level.This table presents estimates of the estimated discontinuity in the relationship between academic outcomes, growth, and child labor variables and the child's village being selected for the BRIGHT program disaggregated by gender and using the indicated specification for equation (1). In Panel C, only activities in which at least 10 percent of children participated are shown and included in Column 10. 
Appendix Tables 
Table A1: Continuity Checks for Individual Measures of House Quality and Assets

\begin{tabular}{|c|c|c|c|c|c|c|c|}
\hline Household Assets & $\begin{array}{c}\text { Non-Selected } \\
\text { Limit } \\
\text { (1) }\end{array}$ & $\begin{array}{l}\text { Discontinuity } \\
\text { Estimate } \\
\text { (2) }\end{array}$ & $\begin{array}{l}\text { Sample } \\
\text { Size } \\
(3)\end{array}$ & Housing Quality Variables & $\begin{array}{l}\text { Non-Selected } \\
\text { Limit } \\
\text { (3) }\end{array}$ & $\begin{array}{l}\text { Discontinuity } \\
\text { Estimate } \\
\text { (4) }\end{array}$ & $\begin{array}{c}\text { Sample } \\
\text { Size } \\
(3)\end{array}$ \\
\hline Number of Cattle & $\begin{array}{c}5.375^{* * *} \\
(0.396)\end{array}$ & $\begin{array}{c}0.227 \\
(0.480)\end{array}$ & 10,426 & Dirt floor & $\begin{array}{c}0.876^{* * *} \\
(0.012)\end{array}$ & $\begin{array}{r}-0.014 \\
(0.015)\end{array}$ & 10,278 \\
\hline Radios & & & & Quality of Roof & & & \\
\hline None & $\begin{array}{c}0.404 * * * \\
(0.016)\end{array}$ & $\begin{array}{r}-0.002 \\
(0.016)\end{array}$ & 10,426 & Natural & $\begin{array}{c}0.533 * * * \\
(0.030)\end{array}$ & $\begin{array}{l}-0.039 * * \\
(0.019)\end{array}$ & 10,110 \\
\hline One & $\begin{array}{c}0.516 * * * \\
(0.014)\end{array}$ & $\begin{array}{c}0.008 \\
(0.015)\end{array}$ & 10,426 & Rudimentary Material & $\begin{array}{c}0.230 * * * \\
(0.025)\end{array}$ & $\begin{array}{c}0 \\
(0.019)\end{array}$ & 10,110 \\
\hline Two or More & $\begin{array}{c}0.081^{* * *} \\
(0.007)\end{array}$ & $\begin{array}{r}-0.005 \\
(0.009)\end{array}$ & 10,426 & Finished Material & $\begin{array}{c}0.238^{* * *} \\
(0.021)\end{array}$ & $\begin{array}{c}0.039 * \\
(0.021)\end{array}$ & 10,110 \\
\hline Mobile Phones & & & & Water Source: & & & \\
\hline None & $\begin{array}{c}0.320 * * * \\
(0.014)\end{array}$ & $\begin{array}{c}-0.02 \\
(0.017)\end{array}$ & 10,426 & Tube Well or Borehole & $\begin{array}{c}0.559 * * * \\
(0.029)\end{array}$ & $\begin{array}{l}0.068 * * \\
(0.033)\end{array}$ & 10,356 \\
\hline One & $\begin{array}{c}0.540 * * * \\
(0.012)\end{array}$ & $\begin{array}{c}0.012 \\
(0.015)\end{array}$ & 10,426 & Other Type of Well & $\begin{array}{l}0.204 * * * \\
(0.024)\end{array}$ & $\begin{array}{c}-0.03 \\
(0.020)\end{array}$ & 10,356 \\
\hline Two or More & $\begin{array}{c}0.140 * * * \\
(0.010)\end{array}$ & $\begin{array}{r}0.009 \\
(0.013)\end{array}$ & 10,426 & Surface Water & $\begin{array}{c}0.197 * * * \\
(0.022)\end{array}$ & $\begin{array}{l}-0.051^{* *} \\
(0.022)\end{array}$ & 10,356 \\
\hline $\begin{array}{c}\text { Watches } \\
\text { None }\end{array}$ & $\begin{array}{c}0.642^{* * * *} \\
(0.015)\end{array}$ & $\begin{array}{r}-0.004 \\
(0.016)\end{array}$ & 10,426 & Housing Quality Index & $\begin{array}{c}-0.077 \\
(0.051)\end{array}$ & $\begin{array}{c}0.159 * * * \\
(0.060)\end{array}$ & 9,959 \\
\hline One or More & $\begin{array}{c}0.358 * * * \\
(0.015)\end{array}$ & $\begin{array}{c}0.004 \\
(0.016)\end{array}$ & 10,426 & & & & \\
\hline \multicolumn{8}{|l|}{ Bicycles } \\
\hline None & $\begin{array}{c}0.129 * * * \\
(0.015)\end{array}$ & $\begin{array}{l}0.029 * * \\
(0.013)\end{array}$ & 10,426 & & & & \\
\hline One & $\begin{array}{c}0.614 * * * \\
(0.016)\end{array}$ & $\begin{array}{c}-0.01 \\
(0.015)\end{array}$ & 10,426 & & & & \\
\hline Two & $\begin{array}{c}0.140 * * * \\
(0.010)\end{array}$ & $\begin{array}{r}-0.008 \\
(0.009)\end{array}$ & 10,426 & & & & \\
\hline Three or More & $\begin{array}{c}0.116^{* * * *} \\
(0.010)\end{array}$ & $\begin{array}{r}-0.011 \\
(0.009)\end{array}$ & 10,426 & & & & \\
\hline \multicolumn{8}{|l|}{ Motorcycle or Scooter } \\
\hline None & $\begin{array}{c}0.666 * * * \\
(0.014)\end{array}$ & $\begin{array}{r}-0.001 \\
(0.017)\end{array}$ & 10,426 & & & & \\
\hline One or More & $\begin{array}{c}0.334 * * * \\
(0.014)\end{array}$ & $\begin{array}{c}0.001 \\
(0.017)\end{array}$ & 10,426 & & & & \\
\hline \multicolumn{8}{|l|}{ Cart } \\
\hline None & $\begin{array}{c}0.470 * * * \\
(0.017)\end{array}$ & $\begin{array}{r}-0.015 \\
(0.019)\end{array}$ & 10,426 & & & & \\
\hline One & $\begin{array}{c}0.422 * * * \\
(0.014)\end{array}$ & $\begin{array}{c}0.012 \\
(0.015)\end{array}$ & 10,426 & & & & \\
\hline Two or More & $\begin{array}{c}0.108^{* * *} \\
(0.010)\end{array}$ & $\begin{array}{c}0.004 \\
(0.011)\end{array}$ & 10,426 & & & & \\
\hline Household Asset Index & $\begin{array}{r}-0.009 \\
(0.032)\end{array}$ & $\begin{array}{c}0.016 \\
(0.038)\end{array}$ & 10,426 & & & & \\
\hline
\end{tabular}

Note: This table presents evidence of the continuity of the various household asset and housing quality characteristics with respect to the relative score. For each characteristic, Columns 1 and 3 present the average characteristic for children and households in villages that were not selected for the BRIGHT program calculated using no control variables and a quadratic specification for the relative score function. Columns 2 and 4 present the estimated discontinuity in the given characteristic using equation (1) with no control variables and a quadratic specification for the relative score function. Significance at the 1,5 and 10 level is indicated by $* * *, * *$ and $*$ respectively. 
Table A2: Bias Estimates for Enrollment

\begin{tabular}{|c|c|c|c|c|c|c|c|}
\hline & $\begin{array}{c}\text { Discontinuity } \\
\text { Estimate } \\
(1)\end{array}$ & $\begin{array}{c}\text { Enrollment } \\
\text { Coefficient } \\
(2) \\
\end{array}$ & $\begin{array}{c}\text { Bias } \\
\text { Estimate } \\
(3)\end{array}$ & & $\begin{array}{c}\text { Discontinuity } \\
\text { Estimate } \\
(4)\end{array}$ & $\begin{array}{c}\text { Enrollment } \\
\text { Coefficient } \\
\text { (5) }\end{array}$ & $\begin{array}{c}\text { Bias } \\
\text { Estimate } \\
(6)\end{array}$ \\
\hline Child and Household Characteristics: & & & & Household Head Characteristics: & & & \\
\hline Child is Female & $\begin{array}{c}0.015 * \\
(0.008)\end{array}$ & $\begin{array}{c}0.038 * * * \\
(0.006)\end{array}$ & $\begin{array}{c}0.001 * \\
(0.000)\end{array}$ & Has Some Formal Education & $\begin{array}{c}0.030 * * * \\
(0.005)\end{array}$ & $\begin{array}{c}0.080 * * * \\
(0.009)\end{array}$ & $\begin{array}{c}0.002 * \\
(0.001)\end{array}$ \\
\hline Child of Household Head & $\begin{array}{c}0.001 \\
(0.005)\end{array}$ & $\begin{array}{c}0.042^{* * *} \\
(0.009)\end{array}$ & $\begin{array}{c}0.000 \\
(0.000)\end{array}$ & $\begin{array}{l}\text { Religion: } \\
\text { Muslim }\end{array}$ & 0.002 & $0.075^{*}$ & 0.000 \\
\hline Child's Age & $\begin{array}{c}0.078 \\
(0.049)\end{array}$ & $\begin{array}{c}0.005^{* * *} \\
(0.001)\end{array}$ & $\begin{array}{c}0.000 \\
(0.000)\end{array}$ & Christian & $\begin{array}{c}(0.006) \\
0.026^{* * *}\end{array}$ & $\begin{array}{c}(0.040) \\
0.192^{* * *}\end{array}$ & $\begin{array}{c}(0.002) \\
0.005\end{array}$ \\
\hline House Quality Index & $\begin{array}{c}0.180 * * * \\
(0.015)\end{array}$ & $\begin{array}{c}0.054 * * * \\
(0.003)\end{array}$ & $\begin{array}{c}0.010 * * \\
(0.004)\end{array}$ & Animist & $\begin{array}{c}(0.005) \\
-0.025^{* * *}\end{array}$ & $\begin{array}{c}(0.041) \\
0.023\end{array}$ & $\begin{array}{c}(0.005) \\
-0.001\end{array}$ \\
\hline Asset Index & $\begin{array}{c}0.004 \\
(0.017)\end{array}$ & $\begin{array}{c}0.007 * * \\
(0.003)\end{array}$ & $\begin{array}{c}0.000 \\
(0.000)\end{array}$ & Ethnicity: & $(0.006)$ & $(0.040)$ & $(0.001)$ \\
\hline Number of Household Members & $\begin{array}{c}-0.268^{* * *} \\
(0.064)\end{array}$ & $\begin{array}{c}-0.003^{* *} \\
(0.002)\end{array}$ & $\begin{array}{c}0.001 \\
(0.001)\end{array}$ & Mossi & $\begin{array}{c}0.036 * * * \\
(0.005)\end{array}$ & $\begin{array}{c}-0.060 * * * \\
(0.020)\end{array}$ & $\begin{array}{c}-0.002 \\
(0.002)\end{array}$ \\
\hline Number of Children & $\begin{array}{c}-0.148 * * * \\
(0.044)\end{array}$ & $\begin{array}{c}0.002 \\
(0.002)\end{array}$ & $\begin{array}{c}0.000 \\
(0.001)\end{array}$ & Peul & $\begin{array}{c}0.034^{* * *} \\
(0.005)\end{array}$ & $\begin{array}{c}-0.179 * * * \\
(0.023)\end{array}$ & $\begin{array}{c}-0.006 \\
(0.004)\end{array}$ \\
\hline Year's Household in Village & $\begin{array}{c}-0.798^{* * *} \\
(0.270)\end{array}$ & $\begin{array}{c}0.001^{* * *} \\
(0.000)\end{array}$ & $\begin{array}{c}-0.001 \\
(0.000)\end{array}$ & Gourmanche & $\begin{array}{c}-0.030 * * * \\
(0.004)\end{array}$ & $\begin{array}{c}-0.124 * * * \\
(0.024)\end{array}$ & $\begin{array}{c}0.004 \\
(0.003)\end{array}$ \\
\hline & & & & Other & $\begin{array}{c}-0.010 * * * \\
(0.003)\end{array}$ & $\begin{array}{c}-0.065^{* * *} \\
(0.024)\end{array}$ & $\begin{array}{c}0.001 \\
(0.001)\end{array}$ \\
\hline & & & \multicolumn{4}{|c|}{ Total Estimated Bias } & $\begin{array}{c}0.014 \\
(0.008)\end{array}$ \\
\hline
\end{tabular}

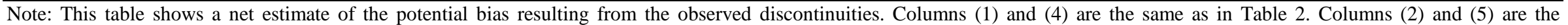

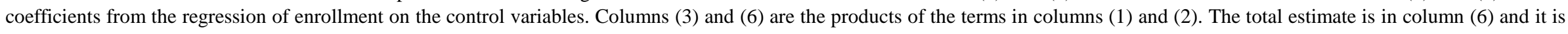
the estimate of the sum of the terms in columns (3) and (6). Significance at the 1, 5 and 10 level is indicated by ***, ** and * respectively. 
Table A3: Bias Estimates for Test Scores

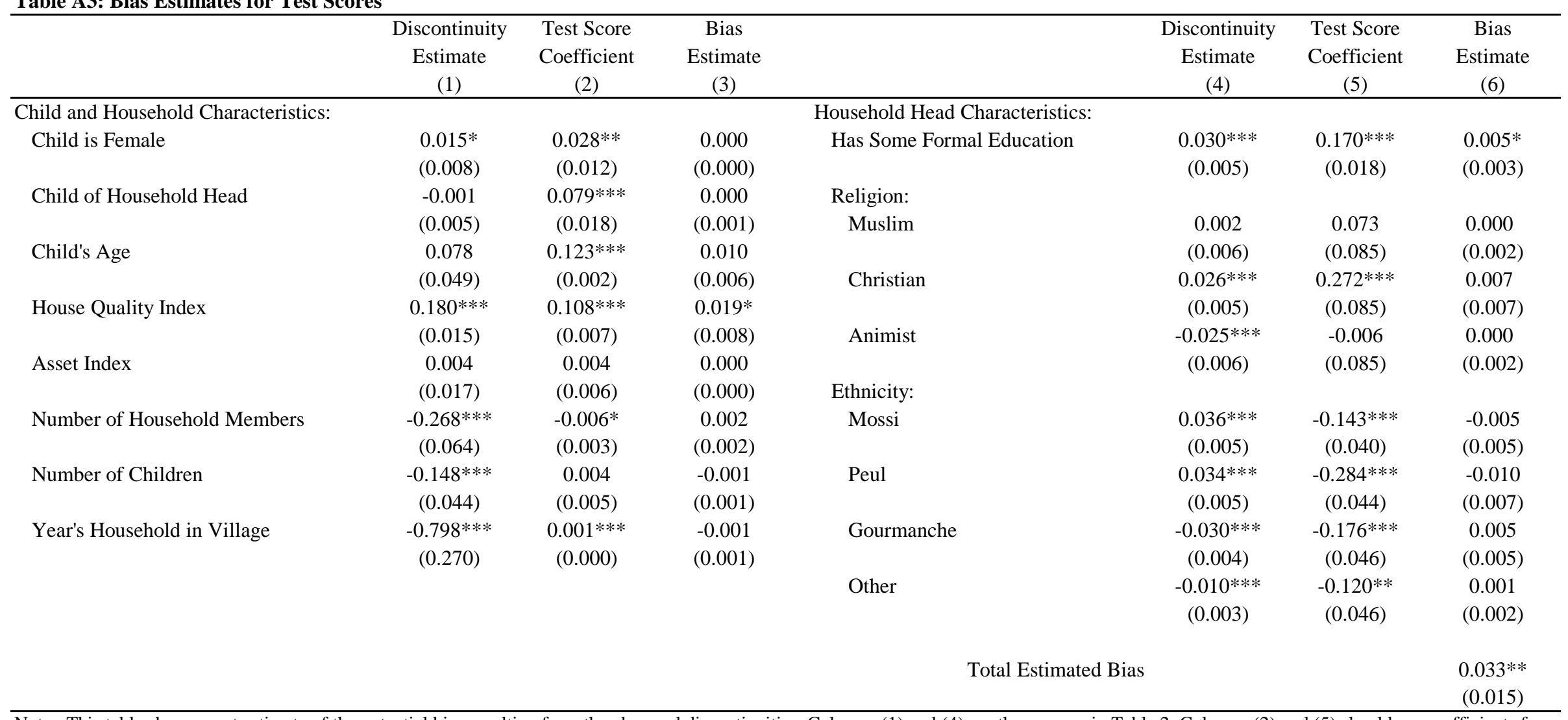

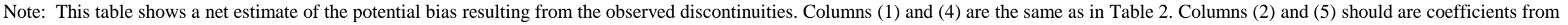

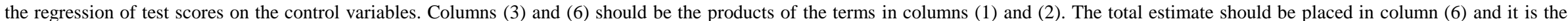
estimate of the sum of the terms in columns (3) and (6). Significance at the 1, 5 and 10 level is indicated by ***, ** and * respectively. 
Table A4: School Characteristics, Household Survey by School

\begin{tabular}{|c|c|c|c|}
\hline & $\begin{array}{c}\text { Non-Selected Limit } \\
\text { (1) }\end{array}$ & $\begin{array}{l}\text { Discontinuity } \\
\text { (2) }\end{array}$ & $\begin{array}{c}\text { Sample Size } \\
\text { (3) }\end{array}$ \\
\hline \multicolumn{4}{|l|}{ Panel A: School Type } \\
\hline Public & $\begin{array}{c}0.956^{* * *} \\
(0.018)\end{array}$ & $\begin{array}{l}-0.017 \\
(0.029)\end{array}$ & 332 \\
\hline Private, Secular & $\begin{array}{c}0.007 \\
(0.010)\end{array}$ & $\begin{array}{c}0.024 \\
(0.016)\end{array}$ & 332 \\
\hline Private, Religious & $\begin{array}{r}0.006 \\
(0.006)\end{array}$ & $\begin{array}{r}0.008 \\
(0.010)\end{array}$ & 332 \\
\hline Madrassa & $\begin{array}{c}0.031^{* * *} \\
(0.012)\end{array}$ & $\begin{array}{l}-0.015 \\
(0.019)\end{array}$ & 332 \\
\hline \multicolumn{4}{|l|}{ Panel B: Accessiblity } \\
\hline Direct Route Available & $\begin{array}{c}0.858 * * * \\
(0.017)\end{array}$ & $\begin{array}{l}0.050 * \\
(0.028)\end{array}$ & 332 \\
\hline Travel Time (Minutes) & $\begin{array}{c}28.819 * * * \\
(1.763)\end{array}$ & $\begin{array}{l}-7.560 * * * \\
(2.822)\end{array}$ & 332 \\
\hline \multicolumn{4}{|l|}{ Panel C: School Resources } \\
\hline Textbooks at School & $\begin{array}{c}0.932 * * * \\
(0.012)\end{array}$ & $\begin{array}{l}0.046 * * \\
(0.019)\end{array}$ & 332 \\
\hline Textbooks for Each Student & $\begin{array}{c}0.743 * * * \\
(0.026)\end{array}$ & $\begin{array}{c}0.022 \\
(0.025)\end{array}$ & 331 \\
\hline Days Teacher Present in Last Week & $\begin{array}{l}4.867 * * * \\
(0.052)\end{array}$ & $\begin{array}{c}0.101 \\
(0.076)\end{array}$ & 332 \\
\hline Separate Latrines & $\begin{array}{l}0.380 * * * \\
(0.031)\end{array}$ & $\begin{array}{l}0.516 * * * \\
(0.047)\end{array}$ & 330 \\
\hline Canteen & $\begin{array}{c}0.618^{* * *} \\
(0.030)\end{array}$ & $\begin{array}{l}0.234^{* * * *} \\
(0.042)\end{array}$ & 332 \\
\hline \multicolumn{4}{|l|}{ Panel D: School Programs } \\
\hline Feeding Program & $\begin{array}{c}0.733^{* * * *} \\
(0.031)\end{array}$ & $\begin{array}{c}0.139 * * * \\
(0.043)\end{array}$ & 332 \\
\hline $\begin{array}{l}\text { Frequency of Feeding Program Operation } \\
\text { (Days per Week) }\end{array}$ & $\begin{array}{l}3.283^{* * * *} \\
(0.146)\end{array}$ & $\begin{array}{l}0.739 * * * \\
(0.202)\end{array}$ & 332 \\
\hline Preschool & $\begin{array}{l}0.104^{* * *} \\
(0.030)\end{array}$ & $\begin{array}{l}0.595^{* * *} \\
(0.050)\end{array}$ & 332 \\
\hline Dry Rations & $\begin{array}{l}0.159 * * * \\
(0.031)\end{array}$ & $\begin{array}{l}0.530 * * * \\
(0.047)\end{array}$ & 332 \\
\hline Dry Rations for Girls Only & $\begin{array}{l}0.154 * * * \\
(0.031)\end{array}$ & $\begin{array}{l}0.511^{* * *} \\
(0.047)\end{array}$ & 332 \\
\hline
\end{tabular}

Note: This table presents estimates of various school characteristics as reported on the household survey based on whether or not the child's village was selected for the BRIGHT program. Only schools visited during the school survey are included. Column 1 presents the average characteristics for schools children in villages that were not selected for the program attended calculated using no control variables and a quadratic specification for the relative score function. Column 2 presents the estimated discontinuity in the given characteristic using equation (1) with no control variables and a quadratic specification for the relative score function. Significance at the 1,5 and 10 level is indicated by $* * *$, ** and * respectively. 
Table A5: General School Characteristics, School Survey

\begin{tabular}{|c|c|c|c|c|c|c|c|}
\hline & $\begin{array}{c}\text { Non-Selected } \\
\text { Limit } \\
\text { (1) }\end{array}$ & $\begin{array}{l}\text { Discon- } \\
\text { tinuity } \\
(2)\end{array}$ & $\begin{array}{l}\text { Sample } \\
\text { Size } \\
(3)\end{array}$ & & $\begin{array}{l}\text { Non-Selected } \\
\text { Limit } \\
\text { (3) }\end{array}$ & $\begin{array}{l}\text { Discon- } \\
\text { tinuity } \\
\text { (4) }\end{array}$ & $\begin{array}{l}\text { Sample } \\
\text { Size } \\
(3)\end{array}$ \\
\hline Panel A: School Type & & & & Panel C: Instruction & & & \\
\hline \multirow[t]{2}{*}{ Public } & $0.958 * * *$ & -0.014 & 332 & Reading Books: & & & \\
\hline & $(0.019)$ & $(0.024)$ & & All students have own & $0.602^{* * *}$ & -0.072 & 330 \\
\hline \multirow[t]{2}{*}{ Private, Secular } & 0.006 & -0.006 & 332 & & $(0.045)$ & $(0.054)$ & \\
\hline & $(0.006)$ & $(0.005)$ & & Most students have own & $0.064^{* * *}$ & 0.057 & 330 \\
\hline \multirow[t]{2}{*}{ Private, Religious } & -0.006 & $0.025^{* *}$ & 332 & & $(0.021)$ & $(0.038)$ & \\
\hline & $(0.006)$ & $(0.012)$ & & Some students have own & $0.032 * *$ & 0.02 & 330 \\
\hline \multirow[t]{2}{*}{ Madrassa } & $0.034^{* *}$ & -0.015 & 332 & & $(0.014)$ & $(0.021)$ & \\
\hline & $(0.015)$ & $(0.017)$ & & Math Books: & & & \\
\hline Panel B: Classrooms & & & & All students have own & $0.540 * * *$ & -0.008 & 329 \\
\hline Construction & & & & & $(0.047)$ & $(0.056)$ & \\
\hline $\begin{array}{c}\text { Natural Materials } \\
\text { (Percentage) }\end{array}$ & $\begin{array}{l}0.265 * * * \\
(0.036)\end{array}$ & $\begin{array}{l}-0.185^{* * *} \\
(0.048)\end{array}$ & 331 & Most students have own & $\begin{array}{l}0.051^{* * *} \\
(0.018)\end{array}$ & $\begin{array}{l}0.073^{* *} \\
(0.037)\end{array}$ & 329 \\
\hline $\begin{array}{c}\text { Finished Materials } \\
\text { (Percentage) }\end{array}$ & $\begin{array}{l}0.748 * * * \\
(0.035)\end{array}$ & $\begin{array}{l}0.184^{* * *} \\
(0.045)\end{array}$ & 332 & Some students have own & $\begin{array}{l}0.057^{* * *} \\
(0.019)\end{array}$ & $\begin{array}{l}-0.023 \\
(0.023)\end{array}$ & 329 \\
\hline Blackboard & & & & French Medium & & & \\
\hline $\begin{array}{c}\text { Any Blackboard } \\
\text { (Percentage) }\end{array}$ & $\begin{array}{l}0.934 * * * \\
(0.018)\end{array}$ & $\begin{array}{l}0.055^{* *} \\
(0.024)\end{array}$ & 332 & Math Instruction & $\begin{array}{l}0.947 * * * \\
(0.017)\end{array}$ & $\begin{array}{c}0.018 \\
(0.024)\end{array}$ & 330 \\
\hline $\begin{array}{l}\text { Visible Blackboard } \\
\text { (Percentage) }\end{array}$ & $\begin{array}{l}0.772 * * * \\
(0.033)\end{array}$ & $\begin{array}{l}0.156^{* * *} \\
(0.041)\end{array}$ & 332 & Reading Instruction & $\begin{array}{l}0.953 * * * \\
(0.017)\end{array}$ & $\begin{array}{r}0.009 \\
(0.021)\end{array}$ & 330 \\
\hline $\begin{array}{l}\text { Rainproof } \\
\text { (Percentage) }\end{array}$ & $\begin{array}{l}0.602 * * * \\
(0.038)\end{array}$ & $\begin{array}{l}0.217^{* * * *} \\
(0.054)\end{array}$ & 331 & General Conversation & $\begin{array}{l}0.875^{* * *} \\
(0.027)\end{array}$ & $\begin{array}{l}0.070^{*} \\
(0.039)\end{array}$ & 328 \\
\hline $\begin{array}{l}\text { Precarious Shelter } \\
\text { (Percentage) }\end{array}$ & $\begin{array}{l}0.209 * * * \\
(0.031)\end{array}$ & $\begin{array}{c}-0.191^{* * *} \\
(0.041)\end{array}$ & 329 & & & & \\
\hline Classroom Quality Index & $\begin{array}{l}-0.231^{* *} \\
(0.100)\end{array}$ & $\begin{array}{l}0.537 * * * \\
(0.136)\end{array}$ & 328 & & & & \\
\hline
\end{tabular}

Note: This table presents estimates of additional school characteristics for schools based on whether or not the village served by the school was selected for the BRIGHT program. Columns 1 and 3 present the average characteristics for schools in villages that were not selected for the program calculated using no control variables and a quadratic specification for the relative score function. Columns 2 and 4 present the estimated discontinuity in the given characteristic using equation (1) with no control variables and a quadratic specification for the relative score function. Significance at the 1,5 and 10 level is indicated by ***,** and * respectively. 
Table A6: Teacher characteristics, School Survey

\begin{tabular}{|c|c|c|c|c|c|c|c|}
\hline & $\begin{array}{c}\text { Non-Selected } \\
\text { Limit } \\
(1) \\
\end{array}$ & $\begin{array}{c}\text { Discon- } \\
\text { tinuity } \\
(2) \\
\end{array}$ & $\begin{array}{c}\text { Sample } \\
\text { Size } \\
(3) \\
\end{array}$ & & $\begin{array}{c}\text { Non-Selected } \\
\text { Limit } \\
(1) \\
\end{array}$ & $\begin{array}{c}\text { Discon- } \\
\text { tinuity } \\
(2)\end{array}$ & $\begin{array}{c}\text { Sample } \\
\text { Size } \\
(3) \\
\end{array}$ \\
\hline \multicolumn{4}{|l|}{ Panel A: Training } & \multicolumn{4}{|l|}{ Panel C: Teaching Rank } \\
\hline BAC & $\begin{array}{c}0.087 * * * \\
(0.014)\end{array}$ & $\begin{array}{c}0.014 \\
(0.021)\end{array}$ & 331 & Assistant Teacher & $\begin{array}{c}0.052 * * * \\
(0.015)\end{array}$ & $\begin{array}{c}-0.03 \\
(0.019)\end{array}$ & 331 \\
\hline Deug/DetBts & $\begin{array}{l}0.012 * * \\
(0.006)\end{array}$ & $\begin{array}{r}0.005 \\
(0.011)\end{array}$ & 331 & Certified Assistant Teacher & $\begin{array}{l}0.541^{* * *} \\
(0.037)\end{array}$ & $\begin{array}{c}-0.003 \\
(0.037)\end{array}$ & 332 \\
\hline Teaching License & $\begin{array}{c}0.01 \\
(0.007)\end{array}$ & $\begin{array}{c}0.004 \\
(0.012)\end{array}$ & 331 & Certified Teacher & $\begin{array}{c}0.384^{* * *} \\
(0.032)\end{array}$ & $\begin{array}{c}0.016 \\
(0.035)\end{array}$ & 332 \\
\hline \multicolumn{3}{|c|}{ Panel B: Employment Classification } & & Principal Teacher & $0.012^{* *}$ & 0.01 & 330 \\
\hline Permanent & $\begin{array}{c}0.868 * * * \\
(0.030)\end{array}$ & $\begin{array}{l}-0.009 \\
(0.031)\end{array}$ & 332 & Panel D: Experience & $(0.004)$ & $(0.008)$ & \\
\hline Substitute & $\begin{array}{c}0.016 * * * \\
(0.005)\end{array}$ & $\begin{array}{c}0.018 \\
(0.011)\end{array}$ & 331 & Less than 5 years & $\begin{array}{c}0.470^{* * *} \\
(0.032)\end{array}$ & $\begin{array}{c}-0.01 \\
(0.037)\end{array}$ & 332 \\
\hline Principal Teacher & $\begin{array}{l}0.081^{* * *} \\
(0.023)\end{array}$ & $\begin{array}{r}0.004 \\
(0.029)\end{array}$ & 332 & Between 5 and 10 years & $\begin{array}{c}0.467 * * * \\
(0.028)\end{array}$ & $\begin{array}{l}-0.037 \\
(0.037)\end{array}$ & 331 \\
\hline Trainee Teacher & $\begin{array}{c}0.884 * * * \\
(0.027)\end{array}$ & $\begin{array}{l}-0.013 \\
(0.029)\end{array}$ & 332 & More than 10 years & $\begin{array}{c}0.059 * * * \\
(0.015)\end{array}$ & $\begin{array}{l}0.057 * * \\
(0.023)\end{array}$ & 330 \\
\hline \multirow[t]{4}{*}{ Volunteer Teacher } & $\begin{array}{l}0.029 * * \\
(0.011)\end{array}$ & $\begin{array}{r}-0.011 \\
(0.011)\end{array}$ & 332 & $\begin{array}{l}\text { Panel E: Absenteeism } \\
\text { Once per week }\end{array}$ & $\begin{array}{l}0.041^{* *} \\
(0.018)\end{array}$ & $\begin{array}{l}-0.019 \\
(0.030)\end{array}$ & 332 \\
\hline & & & & 2-3 times per month & $\begin{array}{c}0.099 * * * \\
(0.027)\end{array}$ & $\begin{array}{l}-0.011 \\
(0.041)\end{array}$ & 332 \\
\hline & & & & once per month & $\begin{array}{c}0.555^{* * *} \\
(0.047)\end{array}$ & $\begin{array}{r}0.057 \\
(0.067)\end{array}$ & 332 \\
\hline & & & & Less than once per month & $\begin{array}{c}0.306^{* * *} \\
(0.043)\end{array}$ & $\begin{array}{l}-0.027 \\
(0.061)\end{array}$ & 332 \\
\hline
\end{tabular}

Note: This table presents estimates of teacher characteristics for schools based on whether or not the village served by the school was selected for the BRIGHT program. Columns 1 and 3 present the average characteristics for schools in villages that were not selected for the program calculated using no control variables and a quadratic specification for the relative score function. Columns 2 and 4 present the estimated discontinuity in the given characteristic using equation (1) with no control variables and a quadratic specification for the relative score function. Significance at the 1,5 and 10 level is indicated by ***, ** and * respectively. 


\begin{tabular}{|c|c|c|}
\hline & $\begin{array}{l}\text { Unselected } \\
\text { Limit } \\
(1)\end{array}$ & $\begin{array}{c}\text { Estimated } \\
\text { Discontinuity } \\
(2)\end{array}$ \\
\hline \multicolumn{3}{|c|}{ Panel A: Girl-friendly characteristics } \\
\hline Feeding program & 0.746 & $\begin{array}{l}0.247 * * * \\
(0.063)\end{array}$ \\
\hline $\begin{array}{l}\text { Feeding program } \\
\text { Dry rations }\end{array}$ & 0.371 & $\begin{array}{l}0.215^{* * *} \\
(0.051)\end{array}$ \\
\hline Toilets & 0.721 & $\begin{array}{l}0.396 * * * \\
(0.063)\end{array}$ \\
\hline $\begin{array}{l}\text { Toilets } \\
\quad \text { Gender segregated }\end{array}$ & 0.619 & $\begin{array}{l}0.351^{* * *} \\
(0.063)\end{array}$ \\
\hline Daycare & 0.066 & $\begin{array}{l}0.046^{*} \\
(0.025)\end{array}$ \\
\hline \multicolumn{3}{|l|}{ Panel B: School resources } \\
\hline Insufficient textbooks & 0.584 & $\begin{array}{l}-0.182^{* * *} \\
(0.062)\end{array}$ \\
\hline Insufficient desks & 0.188 & $\begin{array}{l}-0.250^{* * *} \\
(0.060)\end{array}$ \\
\hline Water supply & 0.614 & $\begin{array}{l}0.356^{* * *} \\
(0.064)\end{array}$ \\
\hline Number of usable rooms & 3.063 & $\begin{array}{l}0.508^{* * *} \\
(0.179)\end{array}$ \\
\hline Number of blackboards & 3.057 & $\begin{array}{l}0.627 * * * \\
(0.187)\end{array}$ \\
\hline $\begin{array}{l}\text { Number of blackboards } \\
\text { Legible for all students }\end{array}$ & 2.886 & $\begin{array}{l}1.522 * * * \\
(0.389)\end{array}$ \\
\hline \multicolumn{3}{|l|}{ Panel C: Teacher characteristics } \\
\hline Number of teachers & 2.759 & $\begin{array}{c}0.235 \\
(0.207)\end{array}$ \\
\hline $\begin{array}{l}\text { Number of teachers } \\
\text { Female }\end{array}$ & 1.101 & $\begin{array}{l}0.579 * * * \\
(0.143)\end{array}$ \\
\hline $\begin{array}{l}\text { Number of teachers } \\
\text { Postsecondary training }\end{array}$ & 0.127 & $\begin{array}{r}-0.002 \\
(0.051)\end{array}$ \\
\hline $\begin{array}{l}\text { Number of teachers } \\
<5 \text { years' experience }\end{array}$ & 2.032 & $\begin{array}{l}0.505^{* * *} \\
(0.172)\end{array}$ \\
\hline $\begin{array}{l}\text { Number of teachers } \\
\text { 5-10 years' experience }\end{array}$ & 0.576 & $\begin{array}{r}-0.192 \\
(0.121)\end{array}$ \\
\hline $\begin{array}{l}\text { Number of teachers } \\
>10 \text { years' experience }\end{array}$ & 0.152 & $\begin{array}{l}-0.079 \\
(0.057)\end{array}$ \\
\hline $\begin{array}{l}\text { Number of teachers } \\
\text { Gender sensitivity training }\end{array}$ & 0.614 & $\begin{array}{l}0.495^{* * *} \\
(0.092)\end{array}$ \\
\hline
\end{tabular}

Notes: This table presents estimates from the BRIGHT I evaluation of the school characteristics for schools based on whether or not the village served by the school was selected for the BRIGHT program. Column 1 presents the average characteristics for schools in villages that were not selected for the program calculated using no control variables and a quadratic specification for the relative score function. Column 2 presents the estimated discontinuity in the given characteristic using equation (1) with no control variables and quadratic specification for the relative score function. Significance at the 1, 5 and 10 level is indicated by ***, ** and * respectively. 
Table A8: Tabulation of Test Scores by Highest Grade Achieved

\begin{tabular}{|c|c|c|c|c|c|c|c|}
\hline \multirow{2}{*}{$\begin{array}{l}\text { Highest } \\
\text { Grade }\end{array}$} & \multirow{2}{*}{$\begin{array}{c}\text { Fraction of } \\
\text { Sample } \\
\text { (1) }\end{array}$} & \multirow{2}{*}{$\begin{array}{c}\text { Total } \\
\text { Normalized } \\
(2)\end{array}$} & \multicolumn{2}{|c|}{ Math } & \multicolumn{2}{|c|}{ French } & \multirow{2}{*}{$\begin{array}{c}\text { Sample } \\
\text { Size } \\
(7)\end{array}$} \\
\hline & & & $\begin{array}{c}\text { Normalized } \\
\text { (3) } \\
\end{array}$ & $\begin{array}{c}\text { Fraction } \\
\text { Correct } \\
(4)\end{array}$ & Normalized & $\begin{array}{c}\text { Fraction } \\
\text { Correct } \\
(6) \\
\end{array}$ & \\
\hline 8 & $0.01 \%$ & $\begin{array}{c}2.337 \\
(0.000)\end{array}$ & $\begin{array}{c}2.100 \\
(0.000)\end{array}$ & $\begin{array}{c}96.30 \% \\
(0.000)\end{array}$ & $\begin{array}{c}2.435 \\
(0.000)\end{array}$ & $\begin{array}{l}95.83 \% \\
(0.000)\end{array}$ & 2 \\
\hline 7 & $1.07 \%$ & $\begin{array}{c}2.175 \\
(0.495)\end{array}$ & $\begin{array}{c}2.003 \\
(0.489)\end{array}$ & $\begin{array}{l}93.31 \% \\
(0.151)\end{array}$ & $\begin{array}{c}2.188 \\
(0.632)\end{array}$ & $\begin{array}{c}88.08 \% \\
(0.198)\end{array}$ & 280 \\
\hline 6 & $6.91 \%$ & $\begin{array}{c}1.881 \\
(0.630)\end{array}$ & $\begin{array}{c}1.778 \\
(0.586)\end{array}$ & $\begin{array}{c}86.33 \% \\
(0.181)\end{array}$ & $\begin{array}{c}1.874 \\
(0.747)\end{array}$ & $\begin{array}{l}78.24 \% \\
(0.234)\end{array}$ & 1,803 \\
\hline 5 & $6.71 \%$ & $\begin{array}{c}1.432 \\
(0.734)\end{array}$ & $\begin{array}{c}1.369 \\
(0.694)\end{array}$ & $\begin{array}{l}73.70 \% \\
(0.215)\end{array}$ & $\begin{array}{c}1.419 \\
(0.858)\end{array}$ & $\begin{array}{l}63.97 \% \\
(0.269)\end{array}$ & 1,749 \\
\hline 4 & $5.56 \%$ & $\begin{array}{c}1.008 \\
(0.734)\end{array}$ & $\begin{array}{c}1.002 \\
(0.672)\end{array}$ & $\begin{array}{l}62.35 \% \\
(0.208)\end{array}$ & $\begin{array}{c}0.967 \\
(0.894)\end{array}$ & $\begin{array}{l}49.80 \% \\
(0.280)\end{array}$ & 1,449 \\
\hline 3 & $7.22 \%$ & $\begin{array}{c}0.598 \\
(0.721)\end{array}$ & $\begin{array}{c}0.641 \\
(0.674)\end{array}$ & $\begin{array}{l}51.19 \% \\
(0.208)\end{array}$ & $\begin{array}{c}0.542 \\
(0.863)\end{array}$ & $\begin{array}{c}36.47 \% \\
(0.271)\end{array}$ & 1,884 \\
\hline 2 & $6.89 \%$ & $\begin{array}{c}0.087 \\
(0.523)\end{array}$ & $\begin{array}{c}0.114 \\
(0.634)\end{array}$ & $\begin{array}{l}34.92 \% \\
(0.196)\end{array}$ & $\begin{array}{c}0.060 \\
(0.647)\end{array}$ & $\begin{array}{l}21.39 \% \\
(0.203)\end{array}$ & 1,797 \\
\hline 1 & $7.64 \%$ & $\begin{array}{c}-0.389 \\
(0.441)\end{array}$ & $\begin{array}{l}-0.408 \\
(0.519)\end{array}$ & $\begin{array}{l}18.81 \% \\
(0.160)\end{array}$ & $\begin{array}{l}-0.313 \\
(0.439)\end{array}$ & $\begin{array}{l}9.68 \% \\
(0.138)\end{array}$ & 1,992 \\
\hline Preschool & $0.72 \%$ & $\begin{array}{l}-0.744 \\
(0.391)\end{array}$ & $\begin{array}{l}-0.881 \\
(0.386)\end{array}$ & $\begin{array}{l}4.19 \% \\
(0.119)\end{array}$ & $\begin{array}{c}-0.521 \\
(0.400)\end{array}$ & $\begin{array}{l}3.14 \% \\
(0.126)\end{array}$ & 188 \\
\hline None & $57.27 \%$ & $\begin{array}{c}-0.611 \\
(0.307)\end{array}$ & $\begin{array}{l}-0.556 \\
(0.536)\end{array}$ & $\begin{array}{l}14.23 \% \\
(0.165)\end{array}$ & $\begin{array}{l}-0.606 \\
(0.154)\end{array}$ & $\begin{array}{c}0.50 \% \\
(0.046)\end{array}$ & 14,936 \\
\hline
\end{tabular}

Note: This table presents test scores based on the highest grade a child has achieved. Column 1 shows the fraction of the sample that has achieved a particular grade. Column 2 shows normalized total test scores for each grade. Columns 3 and 5 present normalized test scores for Math and French, respectively. Columns 4 and 6 present the fraction of questions correct for Math and French, respectively. Significance at the 1, 5 and 10 level is indicated by ***, ** and * respectively. 


\begin{tabular}{|c|c|c|c|c|c|c|}
\hline \multirow[b]{3}{*}{ Test Section } & \multicolumn{3}{|c|}{ Percent Correct } & \multicolumn{2}{|c|}{ Standardized Score } & \multirow[b]{2}{*}{$\begin{array}{c}\text { Sample } \\
\text { Size }\end{array}$} \\
\hline & $\begin{array}{l}\text { Non-Selected } \\
\text { Limit } \\
\end{array}$ & Discontinuity & $\begin{array}{c}\text { Sample } \\
\text { Size }\end{array}$ & $\begin{array}{c}\text { Non-Selected } \\
\text { Limit } \\
\end{array}$ & Discontinuity & \\
\hline & $(1)$ & $(2)$ & $(3)$ & $(4)$ & (5) & $(6)$ \\
\hline \multicolumn{7}{|l|}{ Panel A: Grade One } \\
\hline Count to Ten (MCP11) & $\begin{array}{c}0.805^{* * *} \\
(0.016)\end{array}$ & $\begin{array}{l}0.024 * * \\
(0.011)\end{array}$ & 25,291 & $\begin{array}{r}-0.016 \\
(0.045)\end{array}$ & $\begin{array}{l}0.068 * * \\
(0.030)\end{array}$ & 25,291 \\
\hline $\begin{array}{l}\text { Number Identification, } \\
\text { Single Digit }\end{array}$ & $\begin{array}{c}0.335^{* * *} \\
(0.016)\end{array}$ & $\begin{array}{l}0.137 * * * \\
(0.016)\end{array}$ & 25,291 & $\begin{array}{l}-0.151^{* * *} \\
(0.034)\end{array}$ & $\begin{array}{c}0.297 * * * \\
(0.034)\end{array}$ & 25,291 \\
\hline Counting Items & $\begin{array}{l}0.648^{* * *} \\
(0.019)\end{array}$ & $\begin{array}{l}0.039 * * * \\
(0.015)\end{array}$ & 25,291 & $\begin{array}{r}-0.028 \\
(0.041)\end{array}$ & $\begin{array}{l}0.084^{* * *} \\
(0.032)\end{array}$ & 25,291 \\
\hline Greater-Than/Less-Than & $\begin{array}{l}0.482 * * * \\
(0.020)\end{array}$ & $\begin{array}{l}0.081^{* * *} \\
(0.016)\end{array}$ & 25,291 & $\begin{array}{l}-0.073^{*} \\
(0.040)\end{array}$ & $\begin{array}{c}0.167 * * * \\
(0.033)\end{array}$ & 25,291 \\
\hline Single Digit Addition & $\begin{array}{l}0.420 * * * \\
(0.018)\end{array}$ & $\begin{array}{l}0.087^{* * *} \\
(0.015)\end{array}$ & 25,291 & $\begin{array}{l}-0.083^{* *} \\
(0.037)\end{array}$ & $\begin{array}{l}0.178^{* * * *} \\
(0.031)\end{array}$ & 25,291 \\
\hline Single Digit Subtraction & $\begin{array}{l}0.381^{* * *} \\
(0.017)\end{array}$ & $\begin{array}{l}0.086^{* * *} \\
(0.015)\end{array}$ & 25,291 & $\begin{array}{l}-0.085^{* *} \\
(0.036)\end{array}$ & $\begin{array}{l}0.181 * * * \\
(0.031)\end{array}$ & 25,291 \\
\hline Grade 1 Total & $\begin{array}{c}0.485^{* * *} \\
(0.016)\end{array}$ & $\begin{array}{l}0.081^{* * *} \\
(0.013)\end{array}$ & 25,291 & $\begin{array}{l}-0.091^{* *} \\
(0.039)\end{array}$ & $\begin{array}{l}0.200 * * * \\
(0.033)\end{array}$ & 25,291 \\
\hline \multicolumn{7}{|l|}{ Panel B: Grade Two } \\
\hline Telling Time & $\begin{array}{l}0.104^{* * *} \\
(0.009)\end{array}$ & $\begin{array}{l}0.072 * * * \\
(0.010)\end{array}$ & 25,291 & $\begin{array}{l}-0.105^{* * *} \\
(0.025)\end{array}$ & $\begin{array}{l}0.208^{* * * *} \\
(0.028)\end{array}$ & 25,291 \\
\hline $\begin{array}{l}\text { Number Identification, } \\
\text { Two Digit }\end{array}$ & $\begin{array}{l}0.185^{* * *} \\
(0.012)\end{array}$ & $\begin{array}{c}0.116^{* * *} \\
(0.013)\end{array}$ & 25,291 & $\begin{array}{l}-0.143^{* * *} \\
(0.029)\end{array}$ & $\begin{array}{l}0.275^{* * *} \\
(0.030)\end{array}$ & 25,291 \\
\hline Multiplication & $\begin{array}{l}0.142 * * * \\
(0.010)\end{array}$ & $\begin{array}{l}0.095 * * * \\
(0.011)\end{array}$ & 25,291 & $\begin{array}{l}-0.135^{* * *} \\
(0.027)\end{array}$ & $\begin{array}{l}0.264 * * * \\
(0.029)\end{array}$ & 25,291 \\
\hline Addition, Two Digit & $\begin{array}{l}0.109 * * * \\
(0.008)\end{array}$ & $\begin{array}{l}0.076^{* * *} \\
(0.010)\end{array}$ & 25,291 & $\begin{array}{l}-0.116^{* * *} \\
(0.024)\end{array}$ & $\begin{array}{l}0.222 * * * \\
(0.028)\end{array}$ & 25,291 \\
\hline Subtraction, Two Digit & $\begin{array}{l}0.105^{* * *} \\
(0.008)\end{array}$ & $\begin{array}{l}0.073^{* * *} \\
(0.010)\end{array}$ & 25,291 & $\begin{array}{c}-0.114 * * * \\
(0.024)\end{array}$ & $\begin{array}{l}0.215^{* * *} \\
(0.029)\end{array}$ & 25,291 \\
\hline Grade 2 Total & $\begin{array}{l}0.127^{* * *} \\
(0.009)\end{array}$ & $\begin{array}{l}0.085^{* * *} \\
(0.010)\end{array}$ & 25,291 & $\begin{array}{c}-0.135^{* * *} \\
(0.027)\end{array}$ & $\begin{array}{l}0.259 * * * \\
(0.030)\end{array}$ & 25,291 \\
\hline \multicolumn{7}{|l|}{ Panel C: Grade Three } \\
\hline Converting Minutes to Hours & $\begin{array}{l}0.063^{* * *} \\
(0.006)\end{array}$ & $\begin{array}{l}0.049 * * * \\
(0.008)\end{array}$ & 25,291 & $\begin{array}{c}-0.089 * * * \\
(0.021)\end{array}$ & $\begin{array}{c}0.173^{* * *} \\
(0.027)\end{array}$ & 25,291 \\
\hline Fraction Identification & $\begin{array}{l}0.049 * * * \\
(0.005)\end{array}$ & $\begin{array}{l}0.040 * * * \\
(0.007)\end{array}$ & 25,291 & $\begin{array}{c}-0.083^{* * *} \\
(0.019)\end{array}$ & $\begin{array}{c}0.158 * * * \\
(0.027)\end{array}$ & 25,291 \\
\hline Identify Parallel Lines & $\begin{array}{c}0.055^{* * *} \\
(0.005)\end{array}$ & $\begin{array}{c}0.048^{* * *} \\
(0.007)\end{array}$ & 25,291 & $\begin{array}{c}-0.095^{* * *} \\
(0.020)\end{array}$ & $\begin{array}{c}0.178 * * * \\
(0.027)\end{array}$ & 25,291 \\
\hline Grade 3 Total & $\begin{array}{c}0.056 * * * \\
(0.005)\end{array}$ & $\begin{array}{c}0.046^{* * *} \\
(0.007)\end{array}$ & $\begin{array}{l}25,291 \\
25,291\end{array}$ & $\begin{array}{c}-0.099 * * * \\
(0.021)\end{array}$ & $\begin{array}{c}0.189 * * * \\
(0.028)\end{array}$ & 25,291 \\
\hline Total Math Score & $\begin{array}{c}0.278^{* * * *} \\
(0.010)\end{array}$ & $\begin{array}{c}0.079 * * * \\
(0.010)\end{array}$ & 25,291 & $\begin{array}{c}-0.126 * * * \\
(0.033)\end{array}$ & $\begin{array}{c}0.256 * * * \\
(0.032)\end{array}$ & 25,291 \\
\hline
\end{tabular}

Note: This table presents estimates of the treatment effects for Math test scores disaggregated by type of question based on whether or not the child's village was selected for the BRIGHT program. Columns 1 and 3 present the percent correct and standardized scores for children in villages that were not selected for the program calculated using no control variables and a quadratic specification for the relative score function. Columns 2 and 4 present the estimated discontinuity in the given characteristic using equation (1) with no control variables and a quadratic specification for the relative score function. Significance at the 1,5 and 10 level is indicated by ***, ** and * respectively. 
Table A10: Estimated Effects by Competancy, French Section

\begin{tabular}{|c|c|c|c|c|c|c|}
\hline \multirow[b]{3}{*}{ Test Section } & \multicolumn{2}{|c|}{ Percent Correct } & \multicolumn{4}{|c|}{ Standardized Score } \\
\hline & \multicolumn{2}{|c|}{ Non-Selected } & \multirow{2}{*}{$\begin{array}{c}\text { Sample } \\
\text { Size }\end{array}$} & $\begin{array}{l}\text { Non-Selected } \\
\text { Limit }\end{array}$ & \multirow[b]{2}{*}{$\frac{\text { Discontinuity }}{(5)}$} & \multirow{2}{*}{$\begin{array}{c}\text { Sample } \\
\text { Size }\end{array}$} \\
\hline & $\begin{array}{c}\text { Limit } \\
(1)\end{array}$ & $\frac{\text { Discontinuity }}{(2)}$ & & $\begin{array}{c}\text { Limit } \\
(4)\end{array}$ & & \\
\hline \multicolumn{7}{|l|}{ Panel A: Grade One } \\
\hline Letter Identification & $\begin{array}{c}0.305^{* * *} \\
(0.017)\end{array}$ & $\begin{array}{l}0.138^{* * * *} \\
(0.017)\end{array}$ & 23,613 & $\begin{array}{c}-0.154^{* * * *} \\
(0.035)\end{array}$ & $\begin{array}{c}0.289 * * * \\
(0.035)\end{array}$ & 23,613 \\
\hline Read Simple Words & $\begin{array}{c}0.216^{* * *} \\
(0.014)\end{array}$ & $\begin{array}{c}0.119 * * * \\
(0.015)\end{array}$ & 23,613 & $\begin{array}{c}-0.151^{* * *} \\
(0.032)\end{array}$ & $\begin{array}{l}0.278 * * * \\
(0.034)\end{array}$ & 23,613 \\
\hline Fill in the Blank & $\begin{array}{c}0.130 * * * \\
(0.009)\end{array}$ & $\begin{array}{c}0.091 * * * \\
(0.012)\end{array}$ & 23,613 & $\begin{array}{c}-0.135 * * * \\
(0.025)\end{array}$ & $\begin{array}{c}0.247 * * * \\
(0.032)\end{array}$ & 23,613 \\
\hline Grade One Total & $\begin{array}{c}0.217^{* * *} \\
(0.013)\end{array}$ & $\begin{array}{c}0.116^{* * * *} \\
(0.014)\end{array}$ & 23,613 & $\begin{array}{c}-0.160^{* * *} \\
(0.033)\end{array}$ & $\begin{array}{c}0.296 * * * \\
(0.036)\end{array}$ & 23,613 \\
\hline Panel B: Grade Two & & & 23,613 & & & 23,613 \\
\hline Letter Identification w/ Accents & $\begin{array}{c}0.164 * * * \\
(0.011)\end{array}$ & $\begin{array}{c}0.110^{* * * *} \\
(0.014)\end{array}$ & 23,613 & $\begin{array}{c}-0.148^{* * *} \\
(0.027)\end{array}$ & $\begin{array}{c}0.272 * * * \\
(0.033)\end{array}$ & 23,613 \\
\hline Match Word to Picture & $\begin{array}{c}0.147^{* * *} \\
(0.010)\end{array}$ & $\begin{array}{c}0.101 * * * \\
(0.013)\end{array}$ & 23,613 & $\begin{array}{c}-0.140 * * * \\
(0.026)\end{array}$ & $\begin{array}{c}0.254 * * * \\
(0.032)\end{array}$ & 23,613 \\
\hline Grade Two Total & $\begin{array}{c}0.160 * * * \\
(0.011)\end{array}$ & $\begin{array}{c}0.108 * * * \\
(0.013)\end{array}$ & & $\begin{array}{c}-0.148^{* * *} \\
(0.027)\end{array}$ & $\begin{array}{c}0.271^{* * *} \\
(0.033)\end{array}$ & \\
\hline Panel C: Grade Three & & & 23,613 & & & 23,613 \\
\hline Identify Sports Words & $\begin{array}{c}0.085^{* * *} \\
(0.007)\end{array}$ & $\begin{array}{c}0.063 * * * \\
(0.009)\end{array}$ & 23,613 & $\begin{array}{c}-0.114^{* * *} \\
(0.024)\end{array}$ & $\begin{array}{l}0.203^{* * *} \\
(0.030)\end{array}$ & 23,613 \\
\hline Verb Tense & $\begin{array}{c}0.045^{* * * *} \\
(0.004)\end{array}$ & $\begin{array}{c}0.049 * * * \\
(0.007)\end{array}$ & 23,613 & $\begin{array}{c}-0.118^{* * *} \\
(0.019)\end{array}$ & $\begin{array}{c}0.219 * * * \\
(0.030)\end{array}$ & 23,613 \\
\hline Noun Forms (Number and Gender) & $\begin{array}{l}0.050 * * * \\
(0.005)\end{array}$ & $\begin{array}{c}0.051^{* * * *} \\
(0.007)\end{array}$ & 23,613 & $\begin{array}{c}-0.107^{* * *} \\
(0.019)\end{array}$ & $\begin{array}{c}0.198 * * * \\
(0.028)\end{array}$ & 23,613 \\
\hline Grade Three Total & $\begin{array}{c}0.057 * * * \\
(0.005)\end{array}$ & $\begin{array}{c}0.053 * * * \\
(0.007)\end{array}$ & 23,613 & $\begin{array}{c}-0.122^{* * *} \\
(0.022)\end{array}$ & $\begin{array}{l}0.224 * * * \\
(0.030)\end{array}$ & 23,613 \\
\hline Total French Score & $\begin{array}{c}0.145^{* * * *} \\
(0.009)\end{array}$ & $\begin{array}{c}0.093^{* * *} \\
(0.011)\end{array}$ & 23,613 & $\begin{array}{c}-0.161^{* * *} \\
(0.029)\end{array}$ & $\begin{array}{l}0.295^{* * *} \\
(0.035)\end{array}$ & 23,613 \\
\hline
\end{tabular}

Note: This table presents estimates of the treatment effects for French test scores disaggregated by type of question based on wehther or not hte child's village was selected for the BRIGHT program. Columns 1 and 3 present the percent correct and standardized scores for children in villages that were not selected for the program calculated using no control variables and a quadratic specification for the relative score function. Columns 2 and 4 present the estimated discontinuity in the given characteristicusing equation (1) with no control variables and a quadratic specification for the relative score function. Significance at the 1,5 and 10 level is indicated by ***, ** and * respectively. 
Table A11: Impacts on Anthropometric Outcomes

\begin{tabular}{|c|c|c|c|c|c|}
\hline & $\begin{array}{l}\text { Non-Selected } \\
\text { Limit } \\
(1)\end{array}$ & $\begin{array}{c}\text { Discontinuity } \\
\text { Estimate } \\
(2)\end{array}$ & & $\begin{array}{c}\text { Non-Selected } \\
\text { Limit } \\
\text { (3) }\end{array}$ & $\begin{array}{c}\text { Discontinuity } \\
\text { Estimate } \\
\text { (4) }\end{array}$ \\
\hline Panel A: Outliers Not Excluded & & & Panel B: Outliers Exclt & & \\
\hline$N=26,024$ & & & $N=26,012$ & & \\
\hline Height for Age & $\begin{array}{c}-0.952 * * * \\
(0.044)\end{array}$ & $\begin{array}{r}-0.053 \\
(0.055)\end{array}$ & Height for Age & $\begin{array}{c}-0.946 * * * \\
(0.045)\end{array}$ & $\begin{array}{r}-0.054 \\
(0.055)\end{array}$ \\
\hline Arm circumference & $\begin{array}{c}161.873^{* * *} \\
(4.818)\end{array}$ & $\begin{array}{c}1.098 \\
(1.096)\end{array}$ & Arm circumference & $\begin{array}{c}161.808^{* * *} \\
(4.814)\end{array}$ & $\begin{array}{r}0.865 \\
(1.089)\end{array}$ \\
\hline BMI & $\begin{array}{c}16.150^{* * *} \\
(0.101)\end{array}$ & $\begin{array}{c}0.022 \\
(0.125)\end{array}$ & BMI & $\begin{array}{c}16.024^{* * *} \\
(0.096)\end{array}$ & $\begin{array}{r}-0.031 \\
(0.103)\end{array}$ \\
\hline \multicolumn{3}{|c|}{$N=14,597($ Weight-for-Age sample which is restricted to ages $6-10)$} & \multicolumn{3}{|c|}{$N=14,541$ (Weight-for-Age sample which is restricted to ages $6-10)$} \\
\hline Height for Age & $\begin{array}{c}-0.639 * * * \\
(0.054)\end{array}$ & $\begin{array}{r}-0.085 \\
(0.066)\end{array}$ & Height for Age & $\begin{array}{c}-0.633^{* * *} \\
(0.054)\end{array}$ & $\begin{array}{r}-0.083 \\
(0.066)\end{array}$ \\
\hline Arm circumference & $\begin{array}{c}149.433^{* * *} \\
(4.163)\end{array}$ & $\begin{array}{r}0.383 \\
(0.863)\end{array}$ & Arm circumference & $\begin{array}{c}149.353^{* * *} \\
(4.168)\end{array}$ & $\begin{array}{r}0.264 \\
(0.856)\end{array}$ \\
\hline BMI & $\begin{array}{c}15.192^{* * *} \\
(0.111)\end{array}$ & $\begin{array}{r}0.083 \\
(0.146)\end{array}$ & BMI & $\begin{array}{c}15.057 * * * \\
(0.100)\end{array}$ & $\begin{array}{r}-0.075 \\
(0.111)\end{array}$ \\
\hline Weight for Age & $\begin{array}{c}-0.963^{* * *} \\
(0.049)\end{array}$ & $\begin{array}{r}-0.082 \\
(0.056)\end{array}$ & Weight for Age & $\begin{array}{c}-0.980 * * * \\
(0.048)\end{array}$ & $\begin{array}{l}-0.103^{*} \\
(0.055)\end{array}$ \\
\hline \multicolumn{3}{|c|}{$N=7,111$ (Weight-for-Height sample which is restricted to heights $65-120 \mathrm{~cm})$} & \multicolumn{3}{|c|}{$N=7,078$ (Weight-for-Height sample which is restricted to heights $65-120 \mathrm{~cm})$} \\
\hline Height for Age & $\begin{array}{c}-1.913^{* * *} \\
(0.064)\end{array}$ & $\begin{array}{r}-0.037 \\
(0.049)\end{array}$ & Height for Age & $\begin{array}{c}-1.913 * * * \\
(0.064)\end{array}$ & $\begin{array}{r}-0.035 \\
(0.049)\end{array}$ \\
\hline Arm circumference & $\begin{array}{c}145.838 * * * \\
(3.352)\end{array}$ & $\begin{array}{c}0.443 \\
(0.894)\end{array}$ & Arm circumference & $\begin{array}{c}145.802^{* * *} \\
(3.361)\end{array}$ & $\begin{array}{r}0.385 \\
(0.901)\end{array}$ \\
\hline BMI & $\begin{array}{c}15.791^{* * *} \\
(0.176)\end{array}$ & $\begin{array}{c}0.173 \\
(0.213)\end{array}$ & BMI & $\begin{array}{l}15.638^{* * *} \\
(0.169)\end{array}$ & $\begin{array}{r}-0.033 \\
(0.175)\end{array}$ \\
\hline Weight for Age & $\begin{array}{c}-1.495^{* * *} \\
(0.057)\end{array}$ & $\begin{array}{r}-0.039 \\
(0.069)\end{array}$ & Weight for Age & $\begin{array}{c}-1.519^{* * *} \\
(0.056)\end{array}$ & $\begin{array}{r}-0.067 \\
(0.066)\end{array}$ \\
\hline Weight for Height & $\begin{array}{c}0.02 \\
(0.116)\end{array}$ & $\begin{array}{c}0 \\
(0.110)\end{array}$ & Weight for Height & $\begin{array}{c}-0.032 \\
(0.188)\end{array}$ & $\begin{array}{r}-0.044 \\
(0.106)\end{array}$ \\
\hline
\end{tabular}

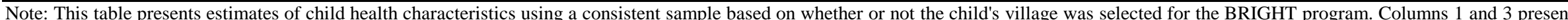

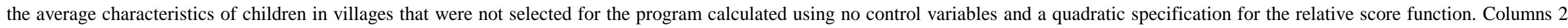

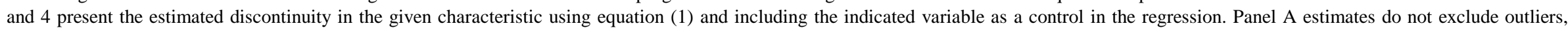
whereas Panel B estimates exclude outliers greater than four standard deviations from the mean. Significance at the 1,5 and 10 level is indicated by ***, ** and * respectively. 
Table A12: Impacts on Child Labor

\begin{tabular}{|c|c|c|c|c|c|c|c|c|c|c|}
\hline & \multirow{2}{*}{$\begin{array}{c}\text { Work in } \\
\text { Other Village } \\
\text { (1) }\end{array}$} & \multicolumn{3}{|c|}{ Work Outside Home in Last Year } & \multicolumn{3}{|c|}{ Work Outside Home in Last Week } & \multicolumn{2}{|c|}{ Household Chores } & \multirow{2}{*}{$\begin{array}{c}\text { Aggregate } \\
\text { Index } \\
(10)\end{array}$} \\
\hline & & $\begin{array}{l}\text { Any } \\
(2)\end{array}$ & $\begin{array}{c}\text { Paid } \\
\text { (3) }\end{array}$ & $\begin{array}{c}\text { Unpaid } \\
\text { (4) }\end{array}$ & $\begin{array}{l}\text { Any } \\
\text { (5) }\end{array}$ & $\begin{array}{c}\text { Paid } \\
(6)\end{array}$ & $\begin{array}{c}\text { Unpaid } \\
\text { (7) }\end{array}$ & $\begin{array}{c}\text { Farming } \\
\text { (8) }\end{array}$ & $\begin{array}{c}\text { Other } \\
\text { (9) }\end{array}$ & \\
\hline Selected for BRIGHT & $\begin{array}{c}0.002 \\
(0.002)\end{array}$ & $\begin{array}{c}0.003 \\
(0.006)\end{array}$ & $\begin{array}{c}0.003 \\
(0.004)\end{array}$ & $\begin{array}{c}0 \\
(0.005)\end{array}$ & $\begin{array}{c}0.002 \\
(0.005)\end{array}$ & $\begin{array}{c}0.005 \\
(0.003)\end{array}$ & $\begin{array}{l}-0.003 \\
(0.004)\end{array}$ & $\begin{array}{c}-0.011 \\
(0.012)\end{array}$ & $\begin{array}{c}-0.004 \\
(0.007)\end{array}$ & $\begin{array}{c}-0.137^{* * *} \\
(0.031)\end{array}$ \\
\hline Relative Score & $\begin{array}{c}-0.011^{* * *} \\
(0.004)\end{array}$ & $\begin{array}{l}-0.009 \\
(0.012)\end{array}$ & $\begin{array}{l}-0.003 \\
(0.006)\end{array}$ & $\begin{array}{l}-0.007 \\
(0.011)\end{array}$ & $\begin{array}{l}-0.007 \\
(0.011)\end{array}$ & $\begin{array}{l}-0.006 \\
(0.005)\end{array}$ & $\begin{array}{l}-0.001 \\
(0.010)\end{array}$ & $\begin{array}{c}0.01 \\
(0.032)\end{array}$ & $\begin{array}{c}0.009 \\
(0.011)\end{array}$ & $\begin{array}{c}0.063 \\
(0.077)\end{array}$ \\
\hline Relative Score`2 & $\begin{array}{c}0.002 * * \\
(0.001)\end{array}$ & $\begin{array}{c}0.001 \\
(0.003)\end{array}$ & $\begin{array}{c}0.000 \\
(0.002)\end{array}$ & $\begin{array}{c}0.001 \\
(0.003)\end{array}$ & $\begin{array}{c}0.001 \\
(0.003)\end{array}$ & $\begin{array}{c}0.001 \\
(0.001)\end{array}$ & $\begin{array}{c}0.000 \\
(0.003)\end{array}$ & $\begin{array}{c}-0.007 \\
(0.008)\end{array}$ & $\begin{array}{c}0.002 \\
(0.003)\end{array}$ & $\begin{array}{c}0.014 \\
(0.021)\end{array}$ \\
\hline Constant & $\begin{array}{c}0.019 * * * \\
(0.006)\end{array}$ & $\begin{array}{l}-0.021 \\
(0.058)\end{array}$ & $\begin{array}{c}0.019 \\
(0.026)\end{array}$ & $\begin{array}{c}-0.04 \\
(0.053)\end{array}$ & $\begin{array}{l}-0.068 \\
(0.054)\end{array}$ & $\begin{array}{c}-0.016^{*} \\
(0.009)\end{array}$ & $\begin{array}{l}-0.052 \\
(0.053)\end{array}$ & $\begin{array}{c}0.203^{* * *} \\
(0.048)\end{array}$ & $\begin{array}{c}-0.056 * * * \\
(0.020)\end{array}$ & $\begin{array}{c}-0.606^{* * *} \\
(0.158)\end{array}$ \\
\hline Observations & 29,434 & 26,430 & 26,430 & 26,430 & 26,430 & 26,430 & 26,430 & 25,186 & 25,192 & 26,430 \\
\hline R-squared & 0.01 & 0.206 & 0.028 & 0.229 & 0.248 & 0.029 & 0.261 & 0.135 & 0.052 & 0.157 \\
\hline Prob $>F$ & 0.000 & 0.000 & 0.000 & 0.000 & 0.000 & 0.000 & 0.000 & 0.000 & 0.000 & 0.000 \\
\hline Demographic controls & Yes & Yes & Yes & Yes & Yes & Yes & Yes & Yes & Yes & Yes \\
\hline Department fixed effects & Yes & Yes & Yes & Yes & Yes & Yes & Yes & Yes & Yes & Yes \\
\hline Non-Selected Limit & $\begin{array}{c}0.019 * * * \\
(0.002)\end{array}$ & $\begin{array}{c}0.077 * * * \\
(0.011)\end{array}$ & $\begin{array}{c}0.016^{* * *} \\
(0.002)\end{array}$ & $\begin{array}{c}0.061^{* * *} \\
(0.011)\end{array}$ & $\begin{array}{c}0.058^{* * *} \\
(0.011)\end{array}$ & $\begin{array}{c}0.007^{* * *} \\
(0.002)\end{array}$ & $\begin{array}{c}0.051^{* * *} \\
(0.010)\end{array}$ & $\begin{array}{c}0.099 * * * \\
(0.013)\end{array}$ & $\begin{array}{c}0.045^{* * *} \\
(0.006)\end{array}$ & $\begin{array}{c}0.053 * \\
(0.029)\end{array}$ \\
\hline Model & Quadratic & Quadratic & Quadratic & Quadratic & Quadratic & Quadratic & Quadratic & Quadratic & Quadratic & Quadratic \\
\hline
\end{tabular}

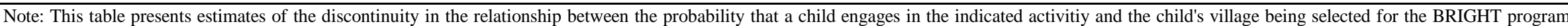

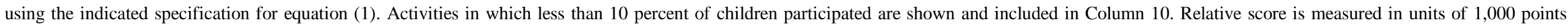
because of the small magnitude of the coefficients. Aggregate index includes activities with more than 10 perent of children. Significance at the 1,5 and 10 level is indicated by ***, ** and * respectively. 
Table A13: BRIGHT Impacts on Enrollment and Test Scores for Children Aged 6 to 12 Years

\begin{tabular}{|c|c|c|c|c|c|c|c|c|c|c|}
\hline & $\begin{array}{c}\text { Reported } \\
\text { Enrollment } \\
(1) \\
\end{array}$ & $\begin{array}{c}\text { Math } \\
\text { Score } \\
(2) \\
\end{array}$ & $\begin{array}{c}\text { French } \\
\text { Score } \\
(3) \\
\end{array}$ & $\begin{array}{c}\text { Highest } \\
\text { Grade } \\
(4)\end{array}$ & $\begin{array}{c}\text { Total } \\
\text { Chores } \\
(5)\end{array}$ & $\begin{array}{c}\text { Reported } \\
\text { Enrollment } \\
(6) \\
\end{array}$ & $\begin{array}{c}\text { Math } \\
\text { Score } \\
(7) \\
\end{array}$ & $\begin{array}{c}\text { French } \\
\text { Score } \\
(8) \\
\end{array}$ & $\begin{array}{c}\text { Highest } \\
\text { Grade } \\
(9)\end{array}$ & $\begin{array}{c}\text { Total } \\
\text { Chores } \\
(10) \\
\end{array}$ \\
\hline Selected for BRIGHT & $\begin{array}{c}0.152^{* * *} \\
(0.02)\end{array}$ & $\begin{array}{c}0.216^{* * * *} \\
(0.03)\end{array}$ & $\begin{array}{c}0.240^{* * *} \\
(0.03)\end{array}$ & $\begin{array}{c}0.552^{* * *} \\
(0.06)\end{array}$ & $\begin{array}{c}-0.280^{* * *} \\
(0.06)\end{array}$ & $\begin{array}{c}0.099 * * * \\
(0.02)\end{array}$ & $\begin{array}{c}0.146^{* * *} \\
(0.03)\end{array}$ & $\begin{array}{c}0.152^{* * *} \\
(0.03)\end{array}$ & $\begin{array}{c}0.366^{* * *} \\
(0.06)\end{array}$ & $\begin{array}{c}-0.226^{* * *} \\
(0.06)\end{array}$ \\
\hline Relative Score & $\begin{array}{c}0.036 \\
(0.04)\end{array}$ & $\begin{array}{c}-0.032 \\
(0.07)\end{array}$ & $\begin{array}{c}0.023 \\
(0.09)\end{array}$ & $\begin{array}{l}0.144 \\
(0.14)\end{array}$ & $\begin{array}{c}0.12 \\
(0.14)\end{array}$ & $\begin{array}{l}0.035 \\
(0.04)\end{array}$ & $\begin{array}{l}-0.033 \\
(0.07)\end{array}$ & $\begin{array}{l}0.022 \\
(0.09)\end{array}$ & $\begin{array}{l}0.143 \\
(0.14)\end{array}$ & $\begin{array}{c}0.12 \\
(0.14)\end{array}$ \\
\hline Relative Score^2 & $\begin{array}{c}-0.01 \\
(0.01)\end{array}$ & $\begin{array}{l}0.005 \\
(0.02)\end{array}$ & $\begin{array}{l}-0.001 \\
(0.02)\end{array}$ & $\begin{array}{l}-0.04 \\
(0.04)\end{array}$ & $\begin{array}{c}0.03 \\
(0.04)\end{array}$ & $\begin{array}{c}-0.009 \\
(0.01)\end{array}$ & $\begin{array}{c}0.006 \\
(0.02)\end{array}$ & $\begin{array}{l}-0.001 \\
(0.02)\end{array}$ & $\begin{array}{l}-0.039 \\
(0.04)\end{array}$ & $\begin{array}{l}0.029 \\
(0.04)\end{array}$ \\
\hline Selected for BRIGHT * Female & & & & & & $\begin{array}{c}0.108 * * * \\
(0.02)\end{array}$ & $\begin{array}{c}0.141^{* * *} \\
(0.03)\end{array}$ & $\begin{array}{c}0.180^{* * *} \\
(0.03)\end{array}$ & $\begin{array}{c}0.379 * * * \\
(0.05)\end{array}$ & $\begin{array}{c}-0.111^{*} \\
(0.06)\end{array}$ \\
\hline Female & $\begin{array}{c}0.043^{* * *} \\
(0.01)\end{array}$ & $\begin{array}{l}0.024^{*} \\
(0.01)\end{array}$ & $\begin{array}{c}0.041 * * * \\
(0.02)\end{array}$ & $\begin{array}{c}0.115^{* * *} \\
(0.03)\end{array}$ & $\begin{array}{c}0.569 * * * \\
(0.03)\end{array}$ & $\begin{array}{c}-0.008 \\
(0.01)\end{array}$ & $\begin{array}{c}-0.042 * * \\
(0.02)\end{array}$ & $\begin{array}{c}-0.043 * * \\
(0.02)\end{array}$ & $\begin{array}{c}-0.062 * \\
(0.03)\end{array}$ & $\begin{array}{c}0.621^{* * *} \\
(0.04)\end{array}$ \\
\hline Constant & $\begin{array}{c}0 \\
-0.063\end{array}$ & $\begin{array}{c}-2.264^{* * *} \\
-0.119\end{array}$ & $\begin{array}{c}-1.795^{* * *} \\
-0.112\end{array}$ & $\begin{array}{c}-2.542^{* * *} \\
-0.204\end{array}$ & $\begin{array}{c}0.757 * * \\
-0.324\end{array}$ & $\begin{array}{c}0.03 \\
-0.063\end{array}$ & $\begin{array}{c}-2.225^{* * *} \\
-0.119\end{array}$ & $\begin{array}{c}-1.745^{* * *} \\
-0.111\end{array}$ & $\begin{array}{c}-2.437 * * * \\
-0.202\end{array}$ & $\begin{array}{c}0.726 * * \\
-0.327\end{array}$ \\
\hline Observations & 19,630 & 18,926 & 17,606 & 19,388 & 19,630 & 19,630 & 18,926 & 17,606 & 19,388 & 19,630 \\
\hline R-squared & 0.178 & 0.379 & 0.257 & 0.317 & 0.166 & 0.181 & 0.381 & 0.26 & 0.32 & 0.166 \\
\hline Prob $>F$ & 0 & 0 & 0 & 0 & 0 & 0 & 0 & 0 & 0 & 0 \\
\hline Demographic controls & Yes & Yes & Yes & Yes & Yes & Yes & Yes & Yes & Yes & Yes \\
\hline Department fixed effects & Yes & Yes & Yes & Yes & Yes & Yes & Yes & Yes & Yes & Yes \\
\hline Non-Selected Limit & $\begin{array}{c}0.338 * * * \\
(0.02)\end{array}$ & $\begin{array}{c}-0.249 * * * \\
(0.03)\end{array}$ & $\begin{array}{c}-0.236^{* * *} \\
(0.03)\end{array}$ & $\begin{array}{c}0.963^{* * *} \\
(0.05)\end{array}$ & $\begin{array}{c}2.692 * * * \\
(0.06)\end{array}$ & $\begin{array}{c}0.03 \\
(0.06)\end{array}$ & $\begin{array}{c}-2.225^{* * *} \\
(0.12)\end{array}$ & $\begin{array}{c}-1.745^{* * *} \\
(0.11)\end{array}$ & $\begin{array}{c}-2.437 * * * \\
(0.20)\end{array}$ & $\begin{array}{c}0.726^{* *} \\
(0.33)\end{array}$ \\
\hline Model & Quadratic & Quadratic & Quadratic & Quadratic & Quadratic & Quadratic & Quadratic & Quadratic & Quadratic & Quadratic \\
\hline
\end{tabular}


Table A14: BRIGHT Impacts on Enrollment and Test Scores for Children Aged 10 to 16 Years

\begin{tabular}{|c|c|c|c|c|c|c|c|c|c|c|}
\hline & $\begin{array}{c}\text { Reported } \\
\text { Enrollment } \\
\text { (1) } \\
\end{array}$ & $\begin{array}{c}\text { Math } \\
\text { Score } \\
(2) \\
\end{array}$ & $\begin{array}{c}\text { French } \\
\text { Score } \\
(3) \\
\end{array}$ & $\begin{array}{l}\text { Highest } \\
\text { Grade } \\
(4)\end{array}$ & $\begin{array}{c}\text { Total } \\
\text { Chores } \\
(5) \\
\end{array}$ & $\begin{array}{c}\text { Reported } \\
\text { Enrollment } \\
(6) \\
\end{array}$ & $\begin{array}{c}\text { Math } \\
\text { Score } \\
(7) \\
\end{array}$ & $\begin{array}{c}\text { French } \\
\text { Score } \\
(8) \\
\end{array}$ & $\begin{array}{c}\text { Highest } \\
\text { Grade } \\
(9)\end{array}$ & $\begin{array}{c}\text { Total } \\
\text { Chores } \\
(10) \\
\end{array}$ \\
\hline Selected for BRIGHT & $\begin{array}{c}0.171^{* * *} \\
(0.02)\end{array}$ & $\begin{array}{c}0.374^{* * *} \\
(0.04)\end{array}$ & $\begin{array}{c}0.445^{* * *} \\
(0.05)\end{array}$ & $\begin{array}{c}1.019 * * * \\
(0.10)\end{array}$ & $\begin{array}{c}-0.206 * * * \\
(0.07)\end{array}$ & $\begin{array}{c}0.103^{* * *} \\
(0.02)\end{array}$ & $\begin{array}{c}0.257^{* * *} \\
(0.05)\end{array}$ & $\begin{array}{c}0.289 * * * \\
(0.05)\end{array}$ & $\begin{array}{c}0.702^{* * *} \\
(0.11)\end{array}$ & $\begin{array}{c}-0.146 * \\
(0.08)\end{array}$ \\
\hline Relative Score & $\begin{array}{l}0.051 \\
(0.04)\end{array}$ & $\begin{array}{l}0.041 \\
(0.09)\end{array}$ & $\begin{array}{l}0.142 \\
(0.13)\end{array}$ & $\begin{array}{c}0.445^{* *} \\
(0.22)\end{array}$ & $\begin{array}{l}-0.017 \\
(0.15)\end{array}$ & $\begin{array}{c}0.05 \\
(0.04)\end{array}$ & $\begin{array}{c}0.04 \\
(0.09)\end{array}$ & $\begin{array}{l}0.141 \\
(0.13)\end{array}$ & $\begin{array}{c}0.441^{* *} \\
(0.22)\end{array}$ & $\begin{array}{l}-0.017 \\
(0.15)\end{array}$ \\
\hline Relative Score^2 & $\begin{array}{l}-0.015 \\
(0.01)\end{array}$ & $\begin{array}{l}-0.014 \\
(0.02)\end{array}$ & $\begin{array}{l}-0.033 \\
(0.04)\end{array}$ & $\begin{array}{c}-0.128 * * \\
(0.06)\end{array}$ & $\begin{array}{l}0.064 \\
(0.04)\end{array}$ & $\begin{array}{c}-0.014 \\
(0.01)\end{array}$ & $\begin{array}{c}-0.012 \\
(0.02)\end{array}$ & $\begin{array}{c}-0.031 \\
(0.04)\end{array}$ & $\begin{array}{c}-0.123^{* *} \\
(0.06)\end{array}$ & $\begin{array}{l}0.063 \\
(0.04)\end{array}$ \\
\hline Selected for BRIGHT $*$ Female & & & & & & $\begin{array}{c}0.138^{* * * *} \\
(0.02)\end{array}$ & $\begin{array}{c}0.238^{* * *} \\
(0.04)\end{array}$ & $\begin{array}{c}0.318^{* * *} \\
(0.05)\end{array}$ & $\begin{array}{c}0.646^{* * *} \\
(0.09)\end{array}$ & $\begin{array}{c}-0.123^{*} \\
(0.07)\end{array}$ \\
\hline Female & $\begin{array}{c}0.033^{* * * *} \\
(0.01)\end{array}$ & $\begin{array}{c}0.01 \\
(0.02)\end{array}$ & $\begin{array}{l}0.019 \\
(0.03)\end{array}$ & $\begin{array}{c}0.101^{* *} \\
(0.05)\end{array}$ & $\begin{array}{c}0.784^{* * *} \\
(0.04)\end{array}$ & $\begin{array}{c}-0.034 * * * \\
(0.01)\end{array}$ & $\begin{array}{c}-0.105^{* * *} \\
(0.03)\end{array}$ & $\begin{array}{c}-0.134 * * * \\
(0.03)\end{array}$ & $\begin{array}{c}-0.210 * * * \\
(0.06)\end{array}$ & $\begin{array}{c}0.843^{* * *} \\
(0.05)\end{array}$ \\
\hline Constant & $\begin{array}{c}0.912 * * * \\
-0.067\end{array}$ & $\begin{array}{c}0.033 \\
-0.158\end{array}$ & $\begin{array}{c}0.113 \\
-0.175\end{array}$ & $\begin{array}{c}1.797^{* * *} \\
-0.308\end{array}$ & $\begin{array}{c}2.984 * * * \\
-0.354\end{array}$ & $\begin{array}{c}0.945^{* * *} \\
-0.066\end{array}$ & $\begin{array}{c}0.09 \\
-0.156\end{array}$ & $\begin{array}{c}0.189 \\
-0.174\end{array}$ & $\begin{array}{c}1.941^{* * *} \\
-0.304\end{array}$ & $\begin{array}{c}2.956 * * * \\
-0.354\end{array}$ \\
\hline Observations & 13,913 & 13,291 & 12,574 & 13,707 & 13,913 & 13,913 & 13,291 & 12,574 & 13,707 & 13,913 \\
\hline R-squared & 0.164 & 0.178 & 0.154 & 0.169 & 0.129 & 0.169 & 0.182 & 0.159 & 0.174 & 0.129 \\
\hline Prob $>F$ & 0 & 0 & 0 & 0 & 0 & 0 & 0 & 0 & 0 & 0 \\
\hline Demographic controls & Yes & Yes & Yes & Yes & Yes & Yes & Yes & Yes & Yes & Yes \\
\hline Department fixed effects & Yes & Yes & Yes & Yes & Yes & Yes & Yes & Yes & Yes & Yes \\
\hline Non-Selected Limit & $\begin{array}{c}0.369 * * * \\
(0.02)\end{array}$ & $\begin{array}{c}0.228 * * * \\
(0.05)\end{array}$ & $\begin{array}{c}0.085^{*} \\
(0.04)\end{array}$ & $\begin{array}{c}1.684^{* * *} \\
(0.10)\end{array}$ & $\begin{array}{c}3.213^{* * *} \\
(0.06)\end{array}$ & $\begin{array}{c}0.945^{* * *} \\
(0.07)\end{array}$ & $\begin{array}{c}0.09 \\
(0.16)\end{array}$ & $\begin{array}{c}0.189 \\
(0.17)\end{array}$ & $\begin{array}{c}1.941^{* * *} \\
(0.30)\end{array}$ & $\begin{array}{c}2.956^{* * *} \\
(0.35)\end{array}$ \\
\hline Model & Quadratic & Quadratic & Quadratic & Quadratic & Quadratic & Quadratic & Quadratic & Quadratic & Quadratic & Quadratic \\
\hline
\end{tabular}

Note: This table presents estimates of the estimated discontinuity in the relationship between a child's probability of being enrolled during the $2012-2013$ academic year and the child's village being selected for the BRIGHT program using the indicated specification for equation (1). Columns 1 and 6 show estimates of the model based on selfreported enrollment information. Columns 4 and 9 use a model based on the highest grade a child achieved in school, regardless of current enrollment. Relative score is measured in units of 1,000 points because of the small magnitude of the coefficients. Column (2) only includes those students who completed the math assessment. Columns

(5) and (10) use the number of "types" of chores completed by a child in a given week. Significance at the 1, 5 and 10 level is indicated by ***, ** and * respectively. 
Table A15: BRIGHT Impacts on Enrollment and Test Scores for Children Aged 13 to 17 Years

\begin{tabular}{|c|c|c|c|c|c|c|c|c|c|c|}
\hline & $\begin{array}{c}\text { Reported } \\
\text { Enrollment } \\
(1)\end{array}$ & $\begin{array}{l}\text { Math } \\
\text { Score } \\
(2) \\
\end{array}$ & $\begin{array}{c}\text { French } \\
\text { Score } \\
(3) \\
\end{array}$ & $\begin{array}{l}\text { Highest } \\
\text { Grade } \\
(4)\end{array}$ & $\begin{array}{c}\text { Total } \\
\text { Chores } \\
(5) \\
\end{array}$ & $\begin{array}{c}\text { Reported } \\
\text { Enrollment } \\
(6)\end{array}$ & $\begin{array}{c}\text { Math } \\
\text { Score } \\
(7) \\
\end{array}$ & $\begin{array}{c}\text { French } \\
\text { Score } \\
(8) \\
\end{array}$ & $\begin{array}{c}\text { Highest } \\
\text { Grade } \\
(9)\end{array}$ & $\begin{array}{c}\text { Total } \\
\text { Chores } \\
(10) \\
\end{array}$ \\
\hline Selected for BRIGHT & $\begin{array}{c}0.161^{* * *} \\
(0.02)\end{array}$ & $\begin{array}{c}0.353^{* * *} \\
(0.05)\end{array}$ & $\begin{array}{c}0.431^{* * *} \\
(0.06)\end{array}$ & $\begin{array}{c}1.029 * * * \\
(0.12)\end{array}$ & $\begin{array}{c}-0.199 * * \\
(0.08)\end{array}$ & $\begin{array}{c}0.104^{* * *} \\
(0.02)\end{array}$ & $\begin{array}{c}0.233^{* * *} \\
(0.06)\end{array}$ & $\begin{array}{c}0.272 * * * \\
(0.07)\end{array}$ & $\begin{array}{c}0.716^{* * *} \\
(0.14)\end{array}$ & $\begin{array}{c}-0.136 \\
(0.10)\end{array}$ \\
\hline Relative Score & $\begin{array}{l}0.021 \\
(0.04)\end{array}$ & $\begin{array}{c}0.07 \\
(0.11)\end{array}$ & $\begin{array}{c}0.194^{*} \\
(0.12)\end{array}$ & $\begin{array}{c}0.462 * * \\
(0.23)\end{array}$ & $\begin{array}{l}0.072 \\
(0.22)\end{array}$ & $\begin{array}{l}0.022 \\
(0.04)\end{array}$ & $\begin{array}{l}0.071 \\
(0.11)\end{array}$ & $\begin{array}{c}0.194 * \\
(0.12)\end{array}$ & $\begin{array}{c}0.470 * * \\
(0.23)\end{array}$ & $\begin{array}{c}0.07 \\
(0.22)\end{array}$ \\
\hline Relative Score^2 & $\begin{array}{l}0.002 \\
(0.01)\end{array}$ & $\begin{array}{l}0.004 \\
(0.03)\end{array}$ & $\begin{array}{l}-0.032 \\
(0.03)\end{array}$ & $\begin{array}{l}-0.102 \\
(0.06)\end{array}$ & $\begin{array}{l}0.035 \\
(0.06)\end{array}$ & $\begin{array}{l}0.003 \\
(0.01)\end{array}$ & $\begin{array}{l}0.005 \\
(0.03)\end{array}$ & $\begin{array}{c}-0.03 \\
(0.03)\end{array}$ & $\begin{array}{c}-0.1 \\
(0.06)\end{array}$ & $\begin{array}{l}0.034 \\
(0.06)\end{array}$ \\
\hline Selected for BRIGHT * Female & & & & & & $\begin{array}{c}0.116^{* * *} \\
(0.03)\end{array}$ & $\begin{array}{c}0.243^{* * *} \\
(0.06)\end{array}$ & $\begin{array}{c}0.322 * * * \\
(0.07)\end{array}$ & $\begin{array}{c}0.633^{* * *} \\
(0.14)\end{array}$ & $\begin{array}{c}-0.126 \\
(0.09)\end{array}$ \\
\hline Female & $\begin{array}{l}0.014 \\
(0.01)\end{array}$ & $\begin{array}{l}-0.014 \\
(0.03)\end{array}$ & $\begin{array}{r}-0.021 \\
(0.04)\end{array}$ & $\begin{array}{l}0.048 \\
(0.07)\end{array}$ & $\begin{array}{c}0.863 * * * \\
(0.05)\end{array}$ & $\begin{array}{c}-0.043^{* * *} \\
(0.02)\end{array}$ & $\begin{array}{c}-0.132 * * * \\
(0.04)\end{array}$ & $\begin{array}{c}-0.177 * * * \\
(0.04)\end{array}$ & $\begin{array}{c}-0.261^{* * *} \\
(0.09)\end{array}$ & $\begin{array}{c}0.925^{* * *} \\
(0.07)\end{array}$ \\
\hline Constant & $\begin{array}{c}1.526 * * * \\
-0.105\end{array}$ & $\begin{array}{c}2.314^{* * *} \\
-0.258\end{array}$ & $\begin{array}{c}2.601^{* * * *} \\
-0.303\end{array}$ & $\begin{array}{c}7.216^{* * * *} \\
-0.589\end{array}$ & $\begin{array}{c}3.719 * * * \\
-0.428\end{array}$ & $\begin{array}{c}1.552^{* * *} \\
-0.104\end{array}$ & $\begin{array}{c}2.371 * * * \\
-0.255\end{array}$ & $\begin{array}{c}2.682 * * * \\
-0.3\end{array}$ & $\begin{array}{c}7.345^{* * *} \\
-0.585\end{array}$ & $\begin{array}{c}3.691 * * * \\
-0.429\end{array}$ \\
\hline Observations & 6,800 & 6,365 & 6,007 & 6,692 & 6,800 & 6,800 & 6,365 & 6,007 & 6,692 & 6,800 \\
\hline R-squared & 0.185 & 0.221 & 0.208 & 0.212 & 0.129 & 0.189 & 0.224 & 0.212 & 0.216 & 0.129 \\
\hline Prob $>F$ & 0 & 0 & 0 & 0 & 0 & 0 & 0 & 0 & 0 & 0 \\
\hline Demographic controls & Yes & Yes & Yes & Yes & Yes & Yes & Yes & Yes & Yes & Yes \\
\hline Department fixed effects & Yes & Yes & Yes & Yes & Yes & Yes & Yes & Yes & Yes & Yes \\
\hline Non-Selected Limit & $\begin{array}{c}0.271^{* * * *} \\
(0.02)\end{array}$ & $\begin{array}{c}0.250^{* * *} \\
(0.05)\end{array}$ & $\begin{array}{l}0.066 \\
(0.05)\end{array}$ & $\begin{array}{c}1.603^{* * *} \\
(0.12)\end{array}$ & $\begin{array}{c}3.313^{* * *} \\
(0.06)\end{array}$ & $\begin{array}{c}1.552^{* * * *} \\
(0.10)\end{array}$ & $\begin{array}{c}2.371 * * * \\
(0.26)\end{array}$ & $\begin{array}{c}2.682^{* * *} \\
(0.30)\end{array}$ & $\begin{array}{c}7.345^{* * *} \\
(0.59)\end{array}$ & $\begin{array}{c}3.691 * * * \\
(0.43)\end{array}$ \\
\hline Model & Quadratic & Quadratic & Quadratic & Quadratic & Quadratic & Quadratic & Quadratic & Quadratic & Quadratic & Quadratic \\
\hline
\end{tabular}

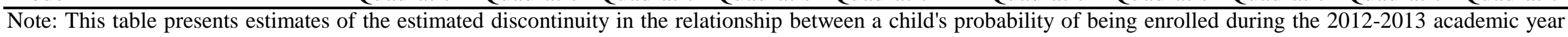

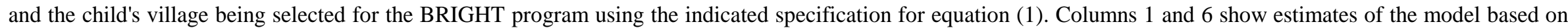

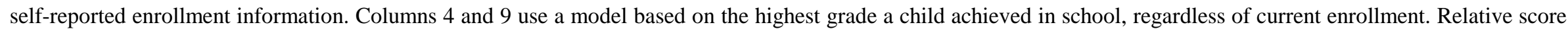

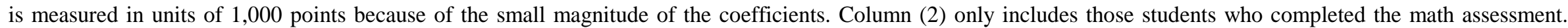

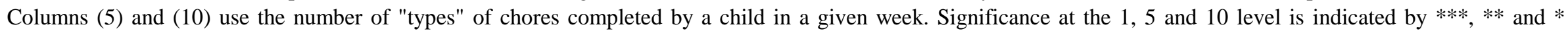
respectively. 
Table A16: BRIGHT Impacts on Enrollment and Test Scores fo Children Ages 6-17 Who Took the Math Exam

\begin{tabular}{|c|c|c|c|c|c|c|c|c|c|c|}
\hline & $\begin{array}{c}\text { Enrollment } \\
\text { According to HH } \\
\text { Survey } \\
(1) \\
\end{array}$ & $\begin{array}{c}\text { Math } \\
\text { normalized } \\
\text { score } \\
(2) \\
\end{array}$ & $\begin{array}{c}\text { French } \\
\text { normalized } \\
\text { score } \\
(3) \\
\end{array}$ & $\begin{array}{c}\text { Highest Grade } \\
\text { Attended } \\
(4) \\
\end{array}$ & $\begin{array}{c}\text { Total } \\
\text { Chores } \\
(5) \\
\end{array}$ & $\begin{array}{c}\text { Enrollment } \\
\text { According to } \\
\text { HH Survey } \\
\text { (6) }\end{array}$ & $\begin{array}{l}\text { Math } \\
\text { normalized } \\
\text { score } \\
(7) \\
\end{array}$ & $\begin{array}{c}\text { French } \\
\text { normalized } \\
\text { score } \\
(8) \\
\end{array}$ & $\begin{array}{c}\text { Highest } \\
\text { Grade } \\
\text { Attended } \\
\text { (9) } \\
\end{array}$ & $\begin{array}{c}\text { Total } \\
\text { Chores } \\
(10) \\
\end{array}$ \\
\hline Selected for BRIGHT & $\begin{array}{c}0.161^{* * *} \\
(0.02)\end{array}$ & $\begin{array}{c}0.256^{* * *} \\
(0.03)\end{array}$ & $\begin{array}{c}0.294^{* * *} \\
(0.04)\end{array}$ & $\begin{array}{c}0.705^{* * *} \\
(0.07)\end{array}$ & $\begin{array}{c}-0.251^{* * *} \\
(0.06)\end{array}$ & $\begin{array}{c}0.105^{* * *} \\
(0.02)\end{array}$ & $\begin{array}{c}0.172^{* * *} \\
(0.03)\end{array}$ & $\begin{array}{c}0.186^{* * *} \\
(0.04)\end{array}$ & $\begin{array}{c}0.473^{* * *} \\
(0.07)\end{array}$ & $\begin{array}{c}-0.187^{* * *} \\
(0.06)\end{array}$ \\
\hline Relative Score & $\begin{array}{l}0.043 \\
(0.04)\end{array}$ & $\begin{array}{l}0.004 \\
(0.07)\end{array}$ & $\begin{array}{l}0.086 \\
(0.09)\end{array}$ & $\begin{array}{c}0.287 * \\
(0.16)\end{array}$ & $\begin{array}{l}0.095 \\
(0.13)\end{array}$ & $\begin{array}{l}0.043 \\
(0.04)\end{array}$ & $\begin{array}{l}0.004 \\
(0.07)\end{array}$ & $\begin{array}{l}0.086 \\
(0.09)\end{array}$ & $\begin{array}{c}0.286 * \\
(0.15)\end{array}$ & $\begin{array}{l}0.095 \\
(0.13)\end{array}$ \\
\hline Relative Score^2 & $\begin{array}{l}-0.01 \\
(0.01)\end{array}$ & $\begin{array}{l}0.001 \\
(0.02)\end{array}$ & $\begin{array}{l}-0.016 \\
(0.02)\end{array}$ & $\begin{array}{c}-0.077 * \\
(0.04)\end{array}$ & $\begin{array}{c}0.03 \\
(0.04)\end{array}$ & $\begin{array}{l}-0.01 \\
(0.01)\end{array}$ & $\begin{array}{l}0.001 \\
(0.02)\end{array}$ & $\begin{array}{l}-0.015 \\
(0.02)\end{array}$ & $\begin{array}{c}-0.075^{*} \\
(0.04)\end{array}$ & $\begin{array}{l}0.029 \\
(0.04)\end{array}$ \\
\hline Selected for BRIGHT * Female & & & & & & $\begin{array}{c}0.114^{* * *} \\
(0.02)\end{array}$ & $\begin{array}{c}0.171^{* * *} \\
(0.03)\end{array}$ & $\begin{array}{c}0.219 * * * \\
(0.03)\end{array}$ & $\begin{array}{c}0.469 * * * \\
(0.06)\end{array}$ & $\begin{array}{c}-0.128^{* *} \\
(0.06)\end{array}$ \\
\hline Female & $\begin{array}{c}0.039 * * * \\
(0.01)\end{array}$ & $\begin{array}{c}0.027^{*} \\
(0.02)\end{array}$ & $\begin{array}{c}0.036^{* *} \\
(0.02)\end{array}$ & $\begin{array}{c}0.128 * * * \\
(0.03)\end{array}$ & $\begin{array}{c}0.651^{* * *} \\
(0.03)\end{array}$ & $\begin{array}{l}-0.014 \\
(0.01)\end{array}$ & $\begin{array}{c}-0.054^{* * *} \\
(0.02)\end{array}$ & $\begin{array}{c}-0.068^{* * *} \\
(0.02)\end{array}$ & $\begin{array}{c}-0.093^{* *} \\
(0.04)\end{array}$ & $\begin{array}{c}0.711^{* * *} \\
(0.04)\end{array}$ \\
\hline Constant & $\begin{array}{c}0.334 * * * \\
-0.052\end{array}$ & $\begin{array}{c}-1.466^{* * *} \\
-0.114\end{array}$ & $\begin{array}{c}-1.109 * * * \\
-0.107\end{array}$ & $\begin{array}{c}-1.005^{* * *} \\
-0.193\end{array}$ & $\begin{array}{c}1.443^{* * *} \\
-0.284\end{array}$ & $\begin{array}{c}0.364^{* * *} \\
-0.052\end{array}$ & $\begin{array}{c}-1.422^{* * *} \\
-0.112\end{array}$ & $\begin{array}{c}-1.052^{* * *} \\
-0.107\end{array}$ & $\begin{array}{c}-0.886 * * * \\
-0.189\end{array}$ & $\begin{array}{c}1.409 * * * \\
-0.287\end{array}$ \\
\hline Observations & 25,291 & 25,291 & 23,464 & 24,985 & 25,291 & 25,291 & 25,291 & 23,464 & 24,985 & 25,291 \\
\hline R-squared & 0.138 & 0.29 & 0.197 & 0.221 & 0.175 & 0.141 & 0.292 & 0.2 & 0.224 & 0.175 \\
\hline Prob $>F$ & 0 & 0 & 0 & 0 & 0 & 0 & 0 & 0 & 0 & 0 \\
\hline Demographic controls & Yes & Yes & Yes & Yes & Yes & Yes & Yes & Yes & Yes & Yes \\
\hline Department fixed effects & Yes & Yes & Yes & Yes & Yes & Yes & Yes & Yes & Yes & Yes \\
\hline Non-Selected Limit & $\begin{array}{c}0.177^{* * *} \\
(0.03)\end{array}$ & $\begin{array}{c}0.263^{* * *} \\
(0.06)\end{array}$ & $\begin{array}{c}0.338^{* * *} \\
(0.05)\end{array}$ & $\begin{array}{c}0.776^{* * *} \\
(0.11)\end{array}$ & $\begin{array}{c}-0.214^{* *} \\
(0.09)\end{array}$ & $\begin{array}{c}0.105^{* * *} \\
\quad(0.02)\end{array}$ & $\begin{array}{c}0.172^{* * *} \\
(0.03)\end{array}$ & $\begin{array}{c}0.186^{* * *} \\
(0.04)\end{array}$ & $\begin{array}{c}0.473^{* * *} \\
(0.07)\end{array}$ & $\begin{array}{c}-0.187^{* * *} \\
(0.06)\end{array}$ \\
\hline Model & Quadratic & Quadratic & Quadratic & Quadratic & Quadratic & Quadratic & Quadratic & Quadratic & Quadratic & Quadratic \\
\hline
\end{tabular}




\section{Question (Score)}

1. Number of 7-year-old girls in your village. $(+1$ pt per girl)

2. Number of girls between 7 and 12 years old in your village. (+1 pt per girl)

3. Number of girls between 7 and 12 years old in your village that are in school. $(+1$ pt per girl)

4. Distance to travel to the nearest school. ( +1 if bet 0 and $5 \mathrm{~km},-1$ if $>6 \mathrm{~km}$ )

5. Number of students at the nearest school. (+1 pt per student)

6. Number of classrooms at the nearest school. (+1 if no rooms, -1 if rooms exist)

7. Number of villages within $3 \mathrm{~km}$ radius. ( +1 if bet 0 and $5 \mathrm{~km},-1$ if $>6 \mathrm{~km}$ )

8. Number of schools for all nearby villages in question 7 . (-1 for each school, +1 if none exist)

9. Distance to the closest schools in villages listed in question 7 . (For each village, +1 if bet 0 and $5 \mathrm{~km},-1$ if $>6 \mathrm{~km}$ )

10. Number of girls between 7 and 12 years old in the villages in question 7 . (+1 pt per girl)

11. Distance from your village to a high school ( +1 if bet 0 and $20 \mathrm{~km},-1$ if $>20 \mathrm{~km}$ )

12. Number of students at the high school. (+1 per student)

13. Name of town where the high school is located. (Not scored)

14. What is your plan for assuring that all girls will be in school? (+1 pt for each action or plan)

15. What is your plan for helping with the unskilled labor needed to build the school? $(+1$ pt for each action or plan)

16. What is your plan for teaching the students' parents to read and write? (+1 pt for each action or plan)

17. How do you propose to participate in the management of the school? ( +1 pt for each action or plan)

Note: This table contains the individual quesitons that comprise the scoring forumula for determing the selection of a village into the BRIGHT program. 